\title{
Impact of Anthropogenic Development on Coastal Ground-Water Hydrology in Southeastern Florida, 1900-2000
}

By Robert A. Renken, Joann Dixon, John Koehmstedt, Scott Ishman, A.C. Lietz, Richard L. Marella, Pamela Telis, Jeff Rodgers, and Steven Memberg

Prepared as part of the

U.S. Geological Survey Greater Everglades Priority Ecosystems Science Program

Circular 1275

U.S. Department of the Interior

U.S. Geological Survey 


\section{U.S. Department of the Interior \\ Gale A. Norton, Secretary}

\section{U.S. Geological Survey Charles G. Groat, Director}

\section{U.S. Geological Survey, Reston, Virginia: 2005}

\section{For sale by U.S. Geological Survey, Information Services}

Box 25286, Denver Federal Center

Denver, CO 80225

For more information about the USGS and its products:

Telephone: 1-888-ASK-USGS

World Wide Web: http://www.usgs.gov/

Any use of trade, product, or firm names in this publication is for descriptive purposes only and does not imply endorsement by the U.S. Government.

Although this report is in the public domain, permission must be secured from the individual copyright owners to reproduce any copyrighted materials contained within this report.

\section{Suggested citation:}

Renken, R.A., Dixon, Joann, Koehmstedt, John, Lietz, A.C., Ishman, Scott, Marella, R.L., Telis, Pamela, Rogers, Jeff and Memberg, Steven, 2005, Impact of Anthropogenic Development on Coastal Ground-Water Hydrology in Southeastern Florida, 1900-2000: Reston, Va., U.S. Geological Survey Circular 1275, 77 p

\section{Library of Congress Cataloging-in-Publication Data}

Impact of anthropogenic development on coastal ground-water hydrology in southeastern Florida, 1900-2000 / by Robert A. Renken ... [et al.] ; prepared as part of the U.S. Geological Survey Greater Everglades Priority Ecosystems Science Program. p. cm. -- (Circular; 1275) Includes bibliographical references.

ISBN 0-607-96286-0 (alk. paper)

1. Water-supply--Florida--Management--Environmental aspects. 2. Land use--Environmental aspects--Florida. 3. Water resources development--Environmental aspects---Florida. 4. Groundwater--Florida. I. Renken, Robert A. II. U.S. Geological Survey Greater Everglades Priority Ecosystems Science Program. III. Geological Survey (U.S.) IV. U.S. Geological Survey circular : 1275 TD224.F6I57 2005 


\section{Contents}

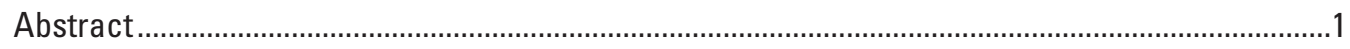

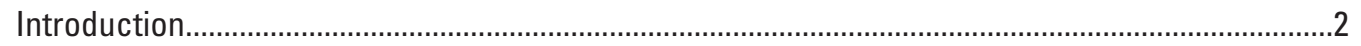

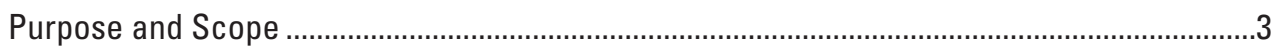

Sources of Land-Use and Population Information .....................................................................

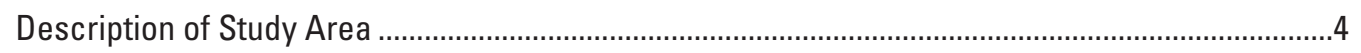

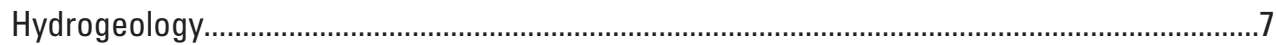

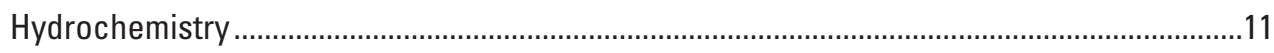

Changes in Land Use and Population Trends................................................................. 14

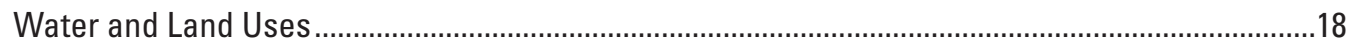

Municipal Withdrawals......................................................................................................... 18

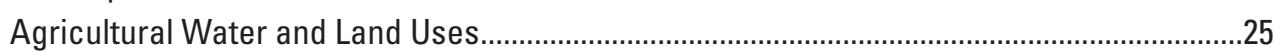

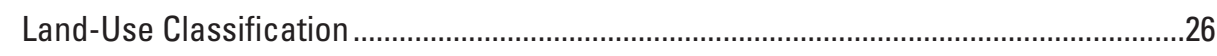

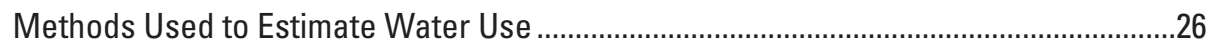

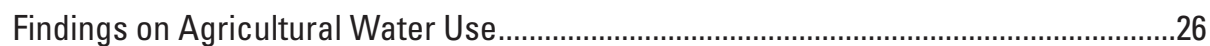

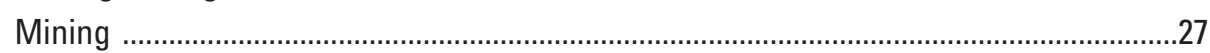

Use of Alternative Aquifers for Supply and Wastewater Management..................................34

Development of Water-Management System and Impact on the Hydrology of

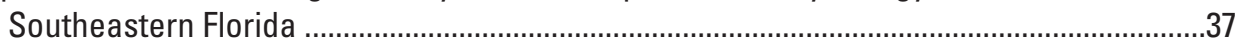

Water-Table Fluctuations of the Surficial Aquifer System..........................................................42

Predevelopment Water-Table Conditions and Ground-Water Flow....................................42

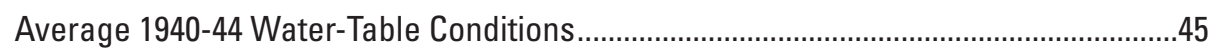

Average 1970-74 Water-Table Conditions....................................................................... 49

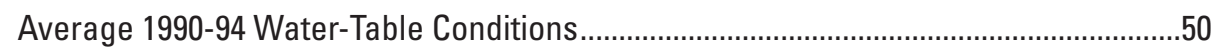

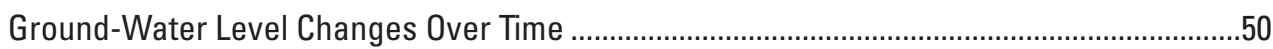

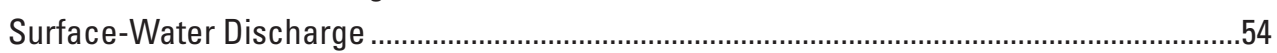

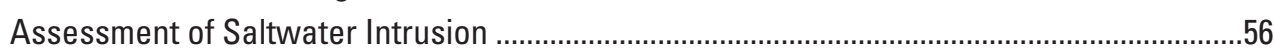

Changes in the Marine Ecosystem of Biscayne Bay .............................................................61

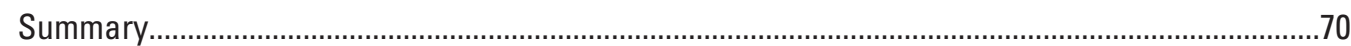

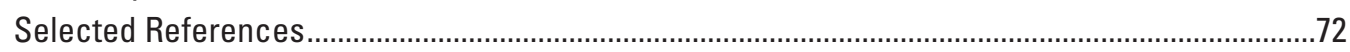




\section{Compact Disc}

[In pocket]

Impact of Anthropogenic Development on Coastal Ground-Water Hydrology in Southeastern Florida, 1900-2000 with Appendix of Geographic Information System (GIS) Data Layers

\section{Figures}

1. Map showing location of the urban-agricultural corridor of southeastern Florida ..........3

2. Graph showing population growth in southeastern Florida, 1900 to $2000 \ldots \ldots \ldots \ldots \ldots \ldots \ldots \ldots . . . . .4$

3-5. Maps showing:

3. Typical average annual, wet-season, and dry-season rainfall patterns in southern Florida

4. Anticipated rainfall during an extreme 3-day rainfall event for a 100 -year return period in southern Florida

5. Physiographic provinces in Miami-Dade, Broward, and Palm Beach Counties.......6

6. Hydrogeologic section showing geologic formations, aquifers, and confining units of the surficial aquifer system in central Miami-Dade County.

7. Maps showing configuration of bedrock surface underlying peat deposits and distribution of peat deposits in southeastern Florida

8. Schematics showing Everglades drainage conveyance features that contributed to a gradual loss of peat and peat soils through subsidence, compaction, and oxidation

9. Map showing base and extent of the surficial aquifer system in southeastern Florida

10. Map showing distribution of transmissivity within the surficial aquifer system in southeastern Florida

11. Fence diagram showing hydrochemical facies within the surficial aquifer system in southeastern Florida

12. Maps showing distribution of dissolved chloride and specific conductance at depths of 50,100, and 150 feet within the surficial aquifer system in southeastern Florida

13-15. Maps showing land-use conditions and population in southeastern Florida during:
13. 1900 and 1920
14. 1940 and 1960
15. 1980 and 2000 
16. Graph showing water use in Miami-Dade, Broward, and Palm Beach Counties, 1965-2000......

17. Pie charts showing ground- and surface-water uses in Miami-Dade, Broward, and Palm Beach Counties by category, 1965 and 2000

18-20. Maps showing municipal ground-water withdrawals in Miami-Dade, Broward, and Palm Beach Counties in:

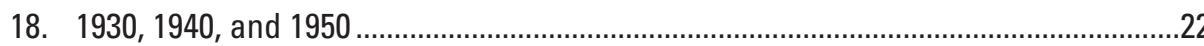

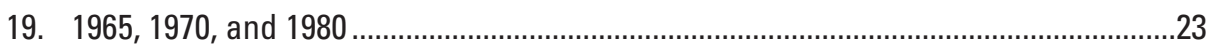

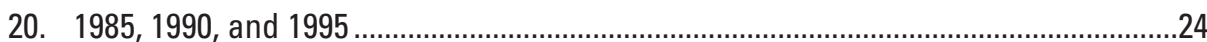

21. Photograph showing workmen cultivating a field of tomatoes near Pompano Beach.

22. Maps showing estimated agricultural water use in Miami-Dade, Broward, and Palm Beach Counties during 1953 and 1977, and, 1988 and 1995

23. Maps showing the extent of limestone borrow pit mines in the Lake Belt area in 1963 and 1975, and, 1984 and 1992

24. Photographs showing Lake Belt limestone borrow-pit mine in Miami-Dade County .....34

25. Photographs showing artificial lakes along the Sawgrass Expressway in reclaimed wetland areas adjoining water-conservation areas in Broward County.......35

26. Maps showing hypothetical aquifer storage and recovery pressure buildup in the Upper Floridan aquifer using the Hantush-Jacob (1955) analytical model, assuming relatively high transmissivity and confining bed leakance or relatively low transmissivity and confining bed leakance

27. Map showing surface-water conveyance features in Miami-Dade, Broward

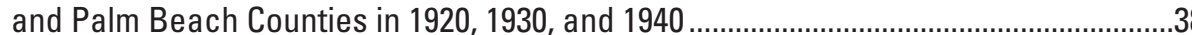

28. Poster used to attract buyers of newly drained agricultural lands

29. Photograph showing dredging of the Miami Canal at Hialeah in 1919 and the South New River Canal at Davie in 1920

30. Political cartoons published for the "Back to Broward League".

31. Poster announcing the historic completion of Hoover Dike at Lake Okeechobee..........41

32. Photographs showing extensive flooding in Hialeah and Fort Lauderdale caused by major hurricanes that hit southeastern Florida in 1947 and 1948, respectively..........41

33. Photograph showing the "weeping cow"

34. Maps showing surface-water conveyance system in Miami-Dade, Broward, and Palm Beach Counties in 1950 and 1960.

35. Maps showing surface-water conveyance system in Miami-Dade, Broward, and Palm Beach Counties in 1970 and 1990

36. Photograph showing gated coastal control structure at the eastern end of

Snake Creek Canal 
37. Diagrams showing canals of southern Florida exhibiting both gaining and losing characteristics depending on relative stage level.

38-40. Maps showing average water levels in the surficial aquifer system in southeastearn Florida during:

38. April 1940-44 and October 1940-44 46

39. April 1970-74 and October 1970-74 47

40. April 1990-94 and October 1990-94

41. Photographs showing City of Miami water well in 1899(?) located at the Miami River headwaters and unidentified man withdrawing water from freshwater spring in Biscayne Bay in 1890 .

42-44. Maps showing average difference in water levels between:

42. April 1940-44 and April 1990-94 and between October 1940-44 and October 1990-94

43. April 1940-44 and April 1970-74 and between October 1940-44 and October 1970-74

44. April 1970-74 and April 1990-94 and between October 1970-74 and October 1990-94

45. Hydrograph showing average departure in rainfall from monthly mean average conditions at 14 sites in southeastern Florida.....

46. Hydrographs showing dampening of variations in ground-water levels following emplacement of the Everglades-South Dade Conveyance System.

47. Map showing location of selected surface-water sites used to monitor canal stage and flow in southeastern Florida...

48. Hydrographs showing long-term mean monthly stage and discharge during the wet season (May-October) and dry season (November-April) at selected surfacewater sites along the coastal reach of major canals in southeastern Florida

49. Hydrographs showing long-term mean monthly stage and discharge during the wet season (May-October) and dry season (November-April) at selected surfacewater sites along the western margin and urban reach of major canals in southeastern Florida

50. Map showing line depicting the landward limit of the saltwater interface in southeastern Florida in 1996

51. Cross sections through the Cutler Ridge area showing lines of equal chloride concentration and the results from a flow-net analysis, September 18, 1958

52. Cross section through the Silver Bluff area showing the zone of diffusion .62

53. Maps showing saltwater intrusion near the Miami Canal in Miami-Dade County, 1904-43 
54. Maps showing saltwater intrusion near the Miami Canal in Miami-Dade County, 1946-62.

55. Maps showing saltwater intrusion near the Miami Canal in Miami-Dade County, 1969-95.

56. Map showing saltwater intrusion in southern Broward and northern MiamiDade Counties in 1945, 1969, and 1993

57. Schematic diagram showing movement of the saltwater interface near the Hallandale Well Field in southern Broward County, 1976-1999..

58. Distribution of selected fauna related to underlying hydrologic factors in the Cutler Ridge area

59. Map showing salinity estimates in Biscayne Bay during 1850-1900 and August $1996 .$.

60. Graphs showing relative abundance of three benthic foraminifera (Articulina mucronata, Archaias angulatus, and Miliolinella circularis) in cores FB1 and MB1 from Biscayne Bay.

\section{Tables}

1. Municipal water use in Miami-Dade, Broward, and Palm Beach Counties from 1930 to 1995.

2-5. Estimated agricultural water use in Miami-Dade, Broward, and Palm Beach Counties in:
. 1953
3. 1977
4. 1983
5. 1995 
Conversion Factors, Abbreviations, Acronyms and Vertical Datum

\begin{tabular}{lll}
\hline Multiply & By & To obtain \\
\hline inch (in.) & 25.4 & millimeter \\
inch per year (in/yr) & 25.4 & millimeter per year \\
foot (ft) & 0.3048 & meter \\
foot per day (ft/d) & 0.3048 & meter per day \\
foot per year (ft/yr) & 0.3048 & meter per year \\
foot squared per day (ft $\left.{ }^{2} / \mathrm{d}\right)$ & 0.09290 & meter squared per day \\
cubic foot per second (ft $/ \mathrm{s})$ & 0.028317 & cubic meter per second \\
mile (mi) & 1.609 & kilometer \\
square mile (mi $\left.{ }^{2}\right)$ & 2.590 & square kilometer \\
acre & 0.4047 & hectare \\
gallon per day (gal/d) & 0.003785 & cubic meter per day \\
gallon per minute (gal/min) & 0.06308 & liter per second \\
million gallons (Mgal) & 3,785 & cubic meter \\
million gallons per day $(\mathrm{Mgal} / \mathrm{d})$ & 0.04381 & cubic meter per second \\
ton, short & 0.9072 & megagram $(\mathrm{Mg})$ \\
\hline
\end{tabular}


Additional abbreviated units

$\mathrm{mg} / \mathrm{L} \quad$ milligrams per liter

ppt parts per thousand

$\mu \mathrm{S} / \mathrm{cm} \quad$ microsiemens per centimeter

\section{Acronyms}

ASR Aquifer storage and recovery

CERP Comprehensive Everglades Restoration Plan

GIRAS Geographic Information Retrieval and Analysis System

GIS Geographic Information System

LWDD Lake Worth Drainage District

SFWMD South Florida Water Management District

USGS U.S. Geological Survey

Temperature in degrees Fahrenheit $\left({ }^{\circ} \mathrm{F}\right)$ may be converted to degrees Celsius $\left({ }^{\circ} \mathrm{C}\right)$ as follows:

${ }^{\circ} \mathrm{C}=\left({ }^{\circ} \mathrm{F}-32\right) / 1.8$

Vertical coordinate information is referenced to the National Geodetic Vertical Datum of 1929 (NGVD 1929); horizontal coordinate information is referenced to the North American Datum of 1983 (NAD83). 



\title{
Impact of Anthropogenic Development on Coastal Ground-Water Hydrology in Southeastern Florida, 1900-2000
}

\author{
By Robert A. Renken, Joann Dixon, John Koehmstedt, A.C. Lietz, Scott Ishman, Richard Marella, Pamela Telis, Jeff Rogers, and Steven Memberg
}

\begin{abstract}
Southeastern Florida is an area that has been subject to widely conflicting anthropogenic stress to the Everglades and coastal ecosystems. This stress is a direct consequence of the $20^{\text {th }}$ century economic competition for limited land and water resources needed to satisfy agricultural development and its expansion, its displacement by burgeoning urban development, and the accompanying growth of the limestone mining industry. The development of a highly controlled water-management system designed to reclaim land for urban and agricultural development has severely impacted the extent, character, and vitality of the historic Everglades and coastal ecosystems. An extensive conveyance system of canals, levees, impoundments, surface-water control structures, and numerous municipal well fields are used to sustain the present-day Everglades hydrologic system, prevent overland flow from moving eastward and flooding urban and agricultural areas, maintain water levels to prevent saltwater intrusion, and provide an adequate water supply. Extractive mining activities expanded considerably in the latter part of the $20^{\text {th }}$ century, largely in response to urban construction needs.

Much of the present-day urban-agricultural corridor of southeastern Florida lies within an area that is no more than 15 feet above NGVD 1929 and formerly characterized by freshwater marsh, upland, and saline coastal wetland ecosystems. MiamiDade, Broward, and Palm Beach Counties have experienced explosive population growth, increasing from less than 4,000 inhabitants in 1900 to more than 5 million in 2000. Ground-water use, the principal source of municipal supply, has increased from about $65 \mathrm{Mgal} / \mathrm{d}$ (million gallons per day) obtained from 3 well fields in 1930
\end{abstract}

to more than $770 \mathrm{Mgal} / \mathrm{d}$ obtained from 65 well fields in 1995 . Water use for agricultural supply increased from $505 \mathrm{Mgal} / \mathrm{d}$ in 1953 to nearly $1,150 \mathrm{Mgal} / \mathrm{d}$ in 1988, but has since declined to $764 \mathrm{Mgal} / \mathrm{d}$ in 1995, partly as a result of displacement of the agricultural industry by urban growth. Present-day agricultural supplies are obtained largely from surface-water sources in Palm Beach County and ground-water sources in Miami-Dade County, whereas Broward County agricultural growers have been largely displaced.

The construction of a complex canal drainage system and large well fields has substantially altered the surface- and ground-water hydrologic systems. The drainage system constructed between 1910 and 1928 mostly failed to transport flood flows, however, and exacerbated periods of low rainfall and drought by overdraining the surficial aquifer system. Following completion of the 1930s Hoover Dike levee system that was designed to reduce Lake Okeechobee flood flows, the Central and Southern Florida Flood Control Project initiated the restructure of the existing conveyance system in 1948 through canal expansion, construction of protective levees and control structures, and greater management of ground-water levels in the surficial aquifer system.

Gated canal control structures discharge excess surface water during the wet season and remain closed during the dry season to induce recharge by canal seepage and well withdrawals. Management of surface water through canal systems has successfully maintained lower ground-water levels inland to curb urban and agricultural flooding, and has been used to increase ground-water levels near the coast to impede saltwater intrusion. Coastal discharge, however, appears to have declined, due in part to water being rerouted to secondary canals, and to induced recharge to the surficial aquifer system by large municipal withdrawals. 
Southeastern Florida is underlain by Holocene- to Tertiary-age karstic limestone deposits that form (in descending order): a highly prolific surficial aquifer system, a poorly permeable intermediate confining system, and a permeable Floridan aquifer system. Prior to construction of a complex drainage network, a widespread uppermost veneer of fresh wetland peat and muck deposits served to store water, maintained a higher water table (prolonging the Everglades hydroperiod), and ultimately helped to limit movement of the coastal saltwater interface. The highly permeable Biscayne aquifer, which is part of the surficial aquifer system, yields 1,000 to more than 7,000 gallons per minute to wells. By 2000, the Floridan aquifer system was used for aquifer storage and recovery and reverse osmosis at some sites in southern Florida, but primarily was used for wastewater injection purposes; the efficacy of such systems has been increasingly the subject of public scrutiny.

Prior to construction of the drainage system, the ground-water table reflected Atlantic Coastal Ridge topography, and springs reportedly discharged as freshwater boils. Everglades surface waters discharged southward toward Florida Bay and in the transverse glade areas. The modern-day ground-water table reflects the effect of canal systems, levees, impoundments, and the drawdown effects of larger well fields.

The saltwater interface forms a broad zone of diffusion, and its position is largely a function of lateral movement of seawater from the Atlantic Ocean, seepage from tidal canals, and upconing of relict seawater. Emplacement of conveyance and drainage canals, subsequent compaction and oxidation of inland peat and muck soils (which served previously to maintain higher water levels within the surficial aquifer system, including the Biscayne aquifer), and increased withdrawals from municipal supply wells collectively altered the natural balance between freshwater and saltwater considerably. Saltwater intrusion has been a concern in southeastern Florida since the early 1930s; its effects were most pronounced in Miami-Dade and Broward Counties during the 1940s and 1950s, respectively. Canal drainage appears to have had the most widespread impact on saltwater intrusion, lowering water levels in the surficial aquifer system and contributing to landward movement of the interface.

Core sample paleontologic observations of salinity and the distribution of seagrass in Biscayne Bay and Florida Bay suggest that the coastal marine ecosystem system during the $20^{\text {th }}$ century has been impacted considerably by anthropogenic activities. Land use and water-management practices have increased nutrient loads and other pollutants and increased bay turbidity. Prior to 1900, the Biscayne Bay ecosystem was characterized by much lower marine salinities, including the extreme southern part of the bay, which contained waters that were nearly fresh. Consistent with the progressive inland saltwater intrusion into the surficial aquifer system and the Biscayne aquifer, the increase in salinity interpreted for surface- and groundwater resources in the early 1900s through the 1970s is the result of increased urban development and construction of a canal drainage system. Post-1940 water-management practices to control water discharge greatly affected the Biscayne Bay ecosystem by increasing the frequency, and particularly the magnitude of salinity fluctuations in the 1940s. Clearly, the changes in land use and water-management practices over the long term have had a profound effect on the ground-water hydrology of southeastern Florida.

\section{Introduction}

The urban and agricultural corridor of southeastern Florida generally lies between the Everglades and water-conservation areas to the west and the Atlantic Ocean to the east but includes the Everglades Agricultural Area south of Lake Okeechobee (fig. 1). The area in eastern Miami-Dade, Broward, and Palm Beach Counties is subject to widely opposing stresses on the environment. A highly controlled water-management system evolved during the $20^{\text {th }}$ century to provide drained land for a rapidly expanding population. Drainage of Everglades wetland areas during the last 75 years has provided continuous opportunity for the westward expansion of agricultural, mining, and urban activities. The population of southeastern Florida increased from about 3,500 inhabitants in 1900 to about 5 million in 2000 (fig. 2). The tri-county area under cultivation expanded from about 223,000 acres in 1953 to more than 590,000 acres in 1988 , but declined to about 535,000 acres by 1995.

Surface water is impounded in water-conservation areas that lie west of a protective levee system, partly to: sustain an Everglades ecosystem, keep overland sheetflow from moving eastward and flooding urban and agricultural areas, and use for urban and agricultural water supply. In coastal areas of the urban-agricultural corridor, parallel environmental conflicts exist. Coastal residential and urban areas must be drained for flood control; the underlying surficial aquifer system simultaneously serves as the principal source of water supply, and ground-water levels must be maintained to prevent coastal saltwater intrusion. Ground-water flow patterns have been altered and a reduction in ground-water discharge to coastal bays has modified shallow marine salinity and affected the local ecology.

Rapid urban development and population growth have placed extraordinary demands on the coastal environment in southeastern Florida. Changes in the coastal hydrology of the surficial aquifer system in the region are the direct consequences of water-management practices and concurrent agricultural and urban development. The U.S. Geological Survey (USGS), as part of its Priority Ecosystem Science Program, conducted a study to: (1) assess the hydrologic character of the surficial aquifer system, (2) review the impact of water-management controls on the groundwater system, and (3) examine the manner in which urban and agricultural areas have affected the ambient quality of ground water. 


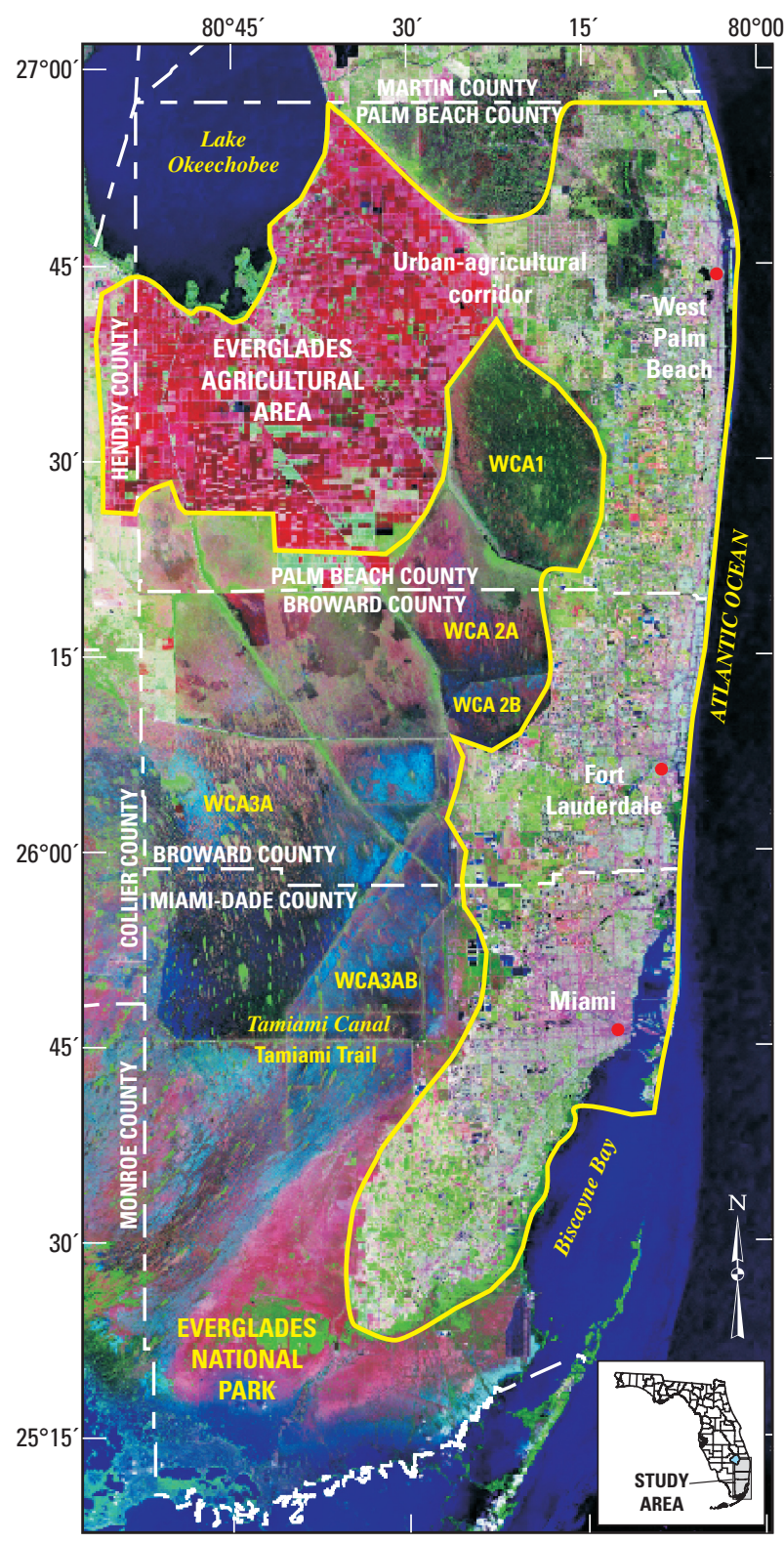

Figure 1. Location of the urban-agricultural corridor of southeastern Florida. The April 1999 map image modified from Earth Satellite Corporation (2004).

\section{Purpose and Scope}

This report provides both a historical and synoptic (predevelopment to the late 1990s) view of the ground-water hydrologic system in southeastern Florida that is of great importance to water managers and urban and environmental planners. The purposes of this report are to:

- Provide a temporal and spatial overview of changes in land use, population, and water management systems;

- Evaluate long-term trends in ground-water withdrawal rates for municipal and agricultural supply;

- Examine long-term change in ground-water levels, trends in surface-water flow, and the change in ground-water chloride concentrations;

- Review causal relations between the position of the saltwater interface and water-management practices; and

- Illustrate the impact of urban development on coastal ground-water hydrology and its effect on the shallow marine hydrology.

Maps, graphs, charts, and photographs are presented to illustrate and define historic and present-day hydrologic conditions in the eastern urban and agricultural corridor of southern Florida.

\section{Sources of Land-Use and Population Information}

All of the land-use maps in this report are compilations from several different sources of historical content, including the following:

- Broward County Department of Land Use, Broward County Planning Council, Fort Lauderdale (Don Waldron, Senior Planner),

- Florida Department of State, Division of Library and Information Services, Bureau of Archives and Records Management, Tallahassee,

- Historical Museum of Southern Florida, Research Center, Miami,

- Miami-Dade Department of Planning and Zoning, Office of Public Works, Miami (Frank McCuene, Administrator),

- Palm Beach County Department of Planning, Zoning and Building, West Palm Beach (Dick Morely, Principal Planner; Marty Hodgkins, Director of Zoning), 


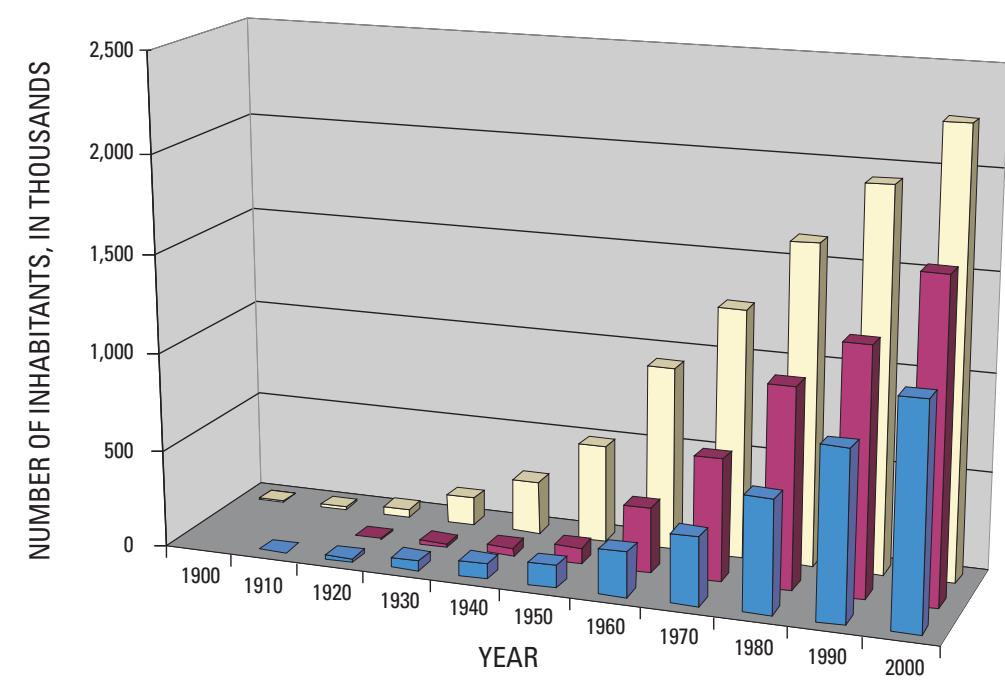

EXPLANATION

$\square$ PALM BEACH COUNTY

$\square$ BROWARD COUNTY

$\square$ MIAMI-DADE COUNTY

Figure 2. Population growth in southeastern Florida, 1900 to 2000. Compiled from files of the U.S. Bureau of the Census (2004).

- University of Florida, Gainesville, Florida History Collection (James Cusick, Curator; Mil Willis, Archivist),

- University of Miami, Coral Gables, Special Collections (Daniel Blazek, Department Head), and

- USGS historical topographic map collections, 1:24,000 scale.

The 1900-1960 land-use maps were compiled, in part, from 1900 and 1953 land-use maps developed by Robert Costanza, Ph.D., University of Maryland. The 1960-2000 land-use maps were compiled, in part, from city or county land-use planning maps, historical maps obtained from the above-mentioned sources, USGS landuse and land-cover maps, and South Florida Water Management District (SFWMD) map data.

\section{Description of Study Area}

Low topographic relief characterizes southeastern Florida, with most areas lying less than $15 \mathrm{ft}$ above NGVD 1929. Prior to development, Miami-Dade, Broward, and Palm Beach Counties included a broad array of aquatic, semiaquatic, and upland habitats. Many of these habitats now have been altered or destroyed as a result of agricultural and urban development. Populated urban areas continue to encroach upon inland agricultural lands and wetland areas.

A warm dry season (November-April) and a hot, humid wet season (MayOctober) characterize the climate of southeastern Florida. The tri-county area (Miami-Dade, Broward, and Palm Beach Counties) is subject to high rates of evapotranspiration, periodic floods and droughts, and infrequent but highly destructive hurricanes. Annual precipitation averages 50 to 62 in., with greatest rainfall amounts occurring in coastal areas (fig. 3A). Between 65 and 80 percent (or between 38 and 46 in.) of the average annual rainfall occurs from May to September due to a nearly daily pattern of thunderstorms and occasional tropical waves and hurricanes (fig. $3 B$ ). Rainfall during November to April ranges from 10 to 17 in., with greatest rainfall occurring near coastal Palm Beach County (fig. 3C). Rainfall patterns in southern Florida exhibit a minor bimodal wet-season peak and a 5- to 6-year cycle that parallels global climate patterns (Duever and others, 1994). Annual rainfall has ranged from a low of 37 in. to a high of 106 in. Periodic extreme climatic events (fig. 4) are generally associated with floods and droughts (South Florida Water Management District, 2000). Mean monthly temperature in degrees Fahrenheit, generally ranges from the 60 s during the winter to the 80 s during the summer. Evapotranspiration losses generally range from 70 to 90 percent of the annual precipitation (U.S. Army Corps of Engineers and the South Florida Water Management District, 1999).

Southeastern Florida consists of several physiographic provinces including the Atlantic Coastal Ridge, Big Cypress Swamp, coastal marshes and mangroves, the Everglades, and the Sandy Flatlands (fig. 5). The Atlantic Coastal Ridge comprises areas of greatest relief in the tri-county area and forms a natural barrier to drainage from interior areas. The ridge extends northward from southeastern Miami-Dade to Palm Beach County and locally is bisected by the natural sloughs and drainage canals. The ridge rises from $8 \mathrm{ft}$ to as much as $24 \mathrm{ft}$ in the north and ranges from 2 to 10 mi wide. The low-lying Sandy Flatlands area lies west of the Atlantic Coastal Ridge. Farther west, the Everglades forms a 30- to 40-mi-wide natural trough (lower than the Sandy Flatlands) that extends southward from Lake Okeechobee and is subject to seasonal flooding. A coastal marsh and mangrove region borders southernmost Miami-Dade County and some parts of Broward and Palm Beach Counties. The Big Cypress Swamp extends into limited areas of northwestern Miami-Dade and southwestern Broward Counties. 

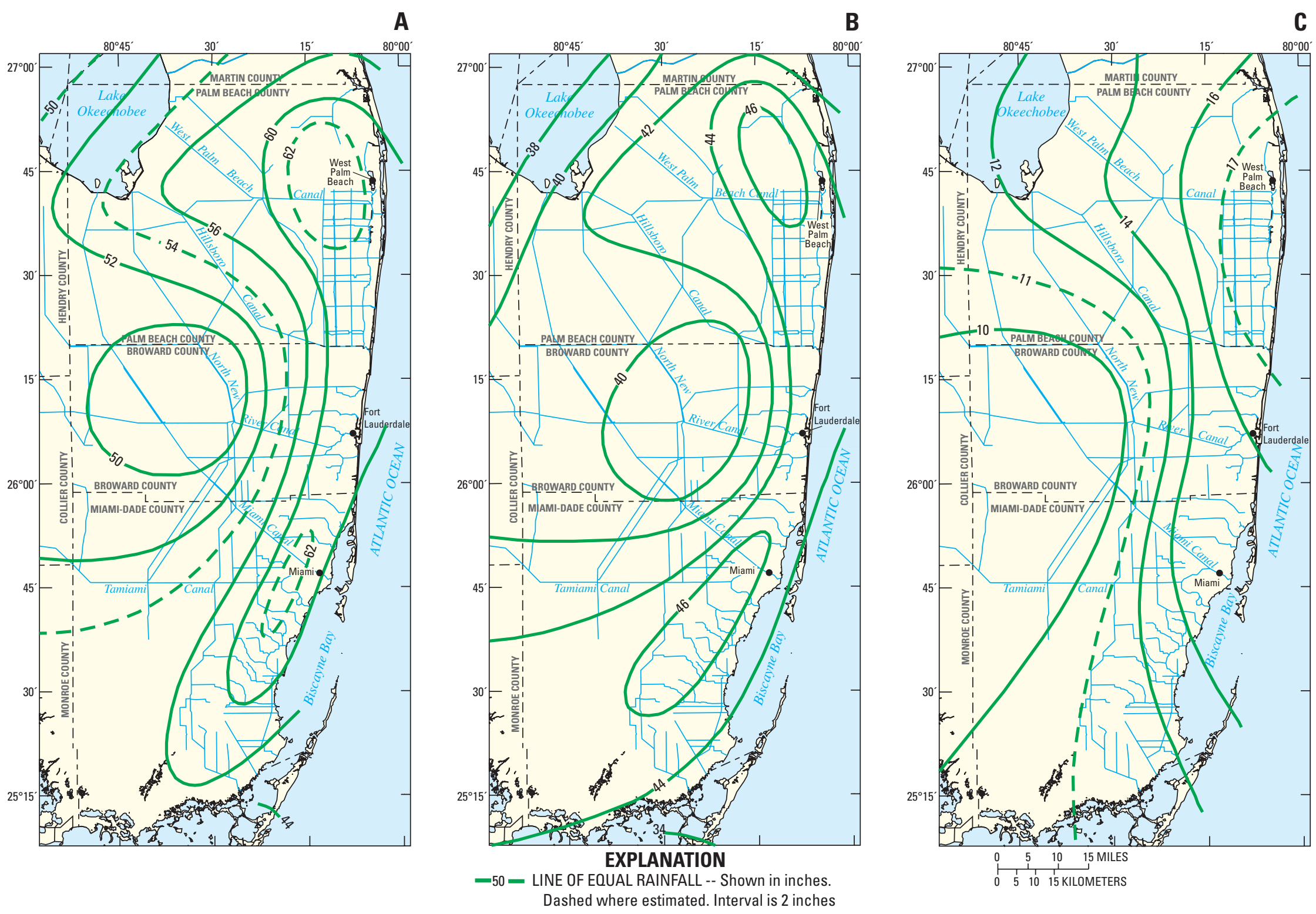

Figure 3. Typical average $(A)$ annual, $(B)$ wet-season, and $(C)$ dry-season rainfall patterns in southern Florida. From South Florida Water Management District (2000). 


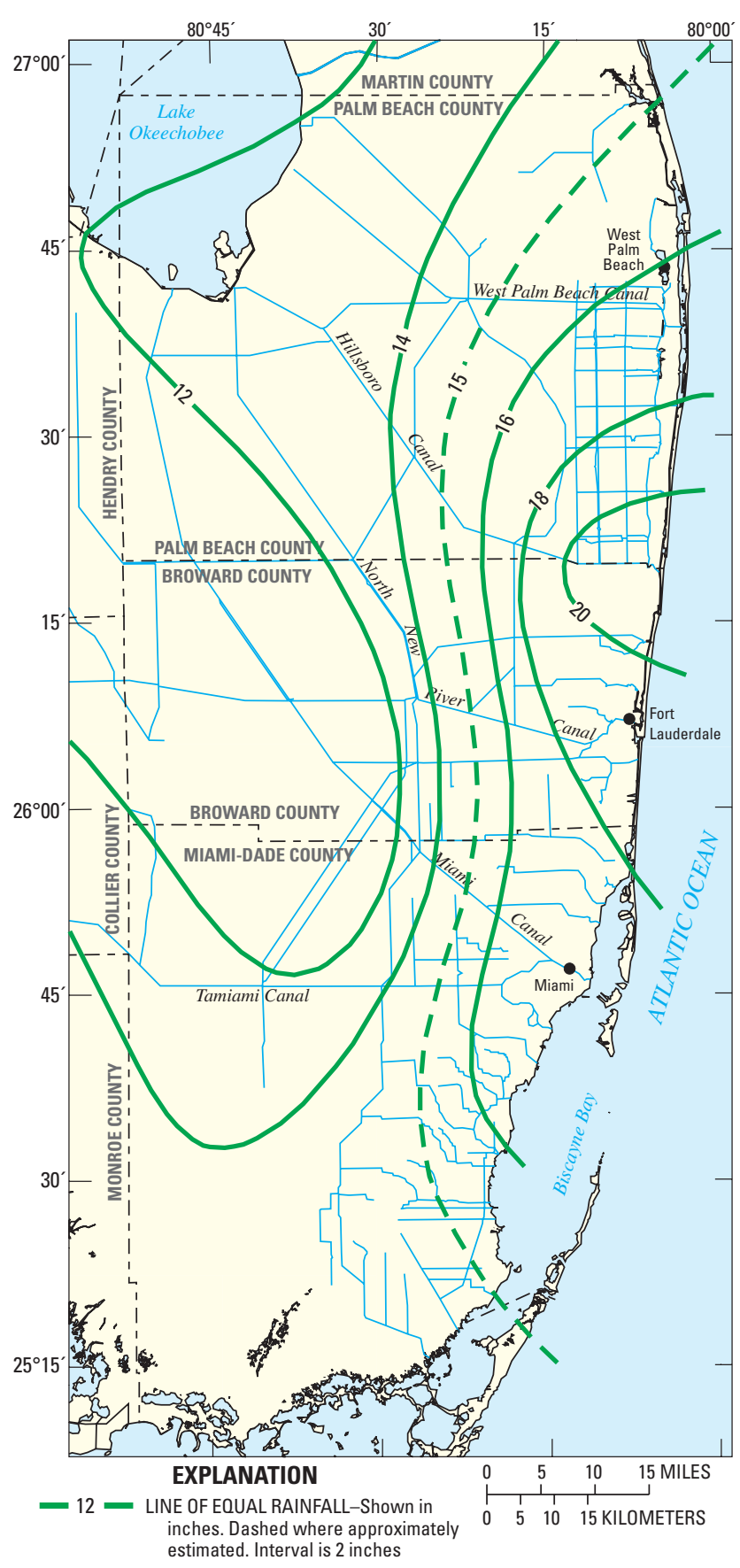

Figure 4. Anticipated rainfall during an extreme 3-day rainfall event for a 100-year return period in southern Florida. From South Florida Water Management District (2000)

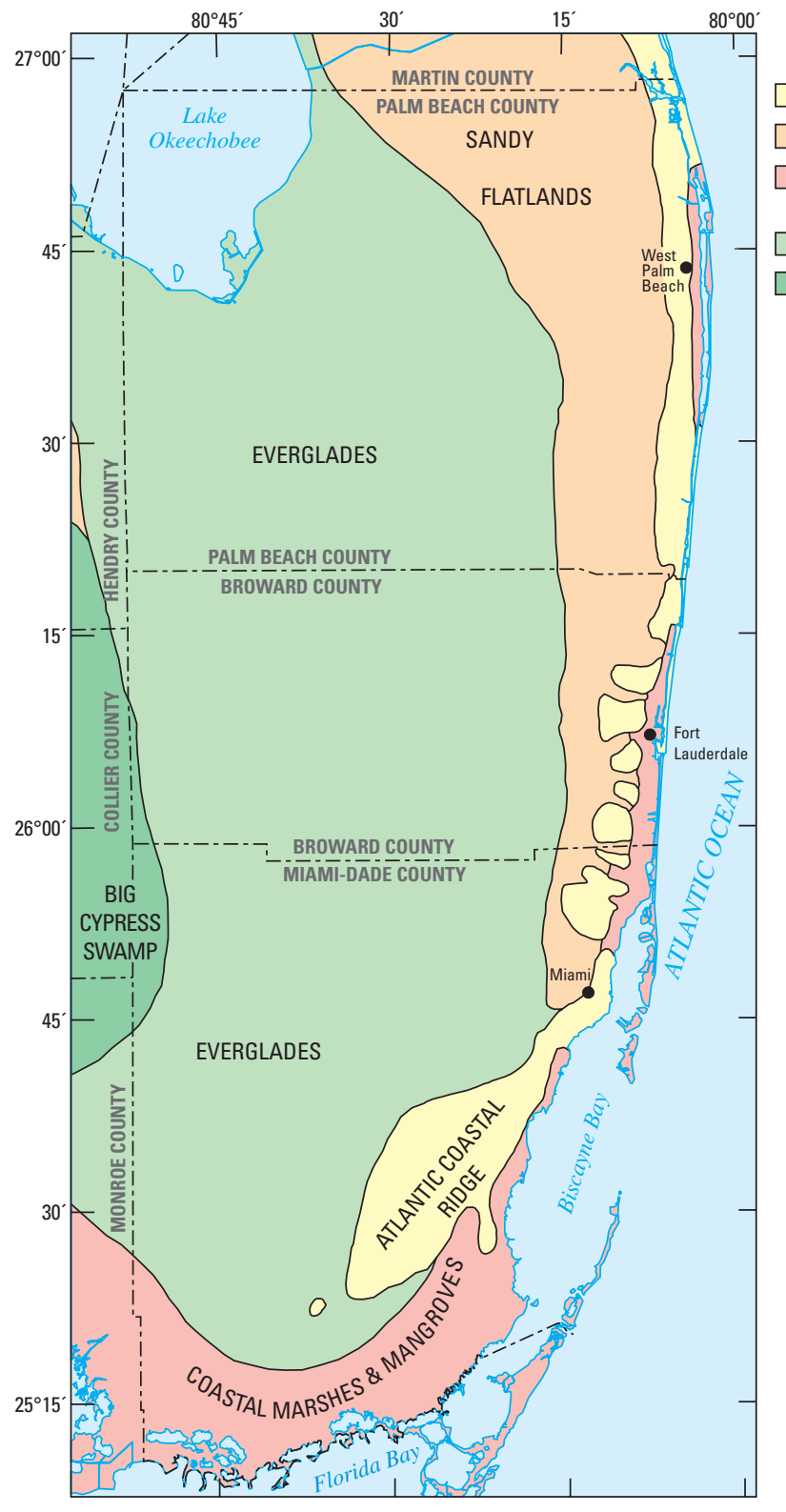

\section{EXPLANATION}

ATLANTIC COASTAL RIDGE

SANDY FLATLANDS

OASTAL MARSHES \&

MANGROVES

EVERGLADES

BIG CYPRESS SWAMP

$\begin{array}{llll}0 & 5 & 10 & 15 \\ 1 & 1 & 1 & 1\end{array}$

Figure 5. Physiographic provinces in MiamiDade, Broward, and Palm Beach Counties. Modified from Davis (1943), and Parker and others (1955). 
The historic Everglades formed an approximate 3,860 $\mathrm{mi}^{2}$ freshwater wetland marsh, extending from Lake Okeechobee to mangrove estuaries that border Florida Bay (fig. 5). Under natural predevelopment conditions, surface water exited the southern shoreline of Lake Okeechobee within eight rivers that traversed a dense custard apple tree swamp (Williams, 1883; Davis, 1943), that transitioned southward into sawgrass plains. Surface water then moved southward into sloughs that formed the Everglades (Davis and others, 1994). The Atlantic Coastal Ridge restricted eastward movement of surface water from the Everglades except in the transverse glades areas of lower elevation that effectively divide the Atlantic Coastal Ridge areas into a series of topographic "islands." The predevelopment Everglades physiographic area generally was covered by surface water over much of its extent, and the low-lying Sandy Flatlands was subject to seasonal flooding.

\section{Hydrogeology}

Miami-Dade, Broward, and Palm Beach County are underlain by deposits of Holocene to Tertiary age, which comprise the surficial aquifer system, intermediate confining unit, and Floridan aquifer system. Holocene deposits that include inland freshwater peat and marl, coastal marsh peat, and beach deposits form a thin veneer overlying the surficial aquifer system - the principal source of water for the tri-county area. The intermediate confining unit underlies the surficial aquifer system and separates it from the deeper Floridan aquifer system (fig. 6)

Large-scale deposition of freshwater peat deposits began about 5,700 to 4,800 years before present, infilling an elongated bedrock trough (fig. 7) that separates the Atlantic Coastal Ridge and Big Cypress Swamp (Gleason and others, 1984). Classified on the basis of plant components (Davis, 1943; Cohen and

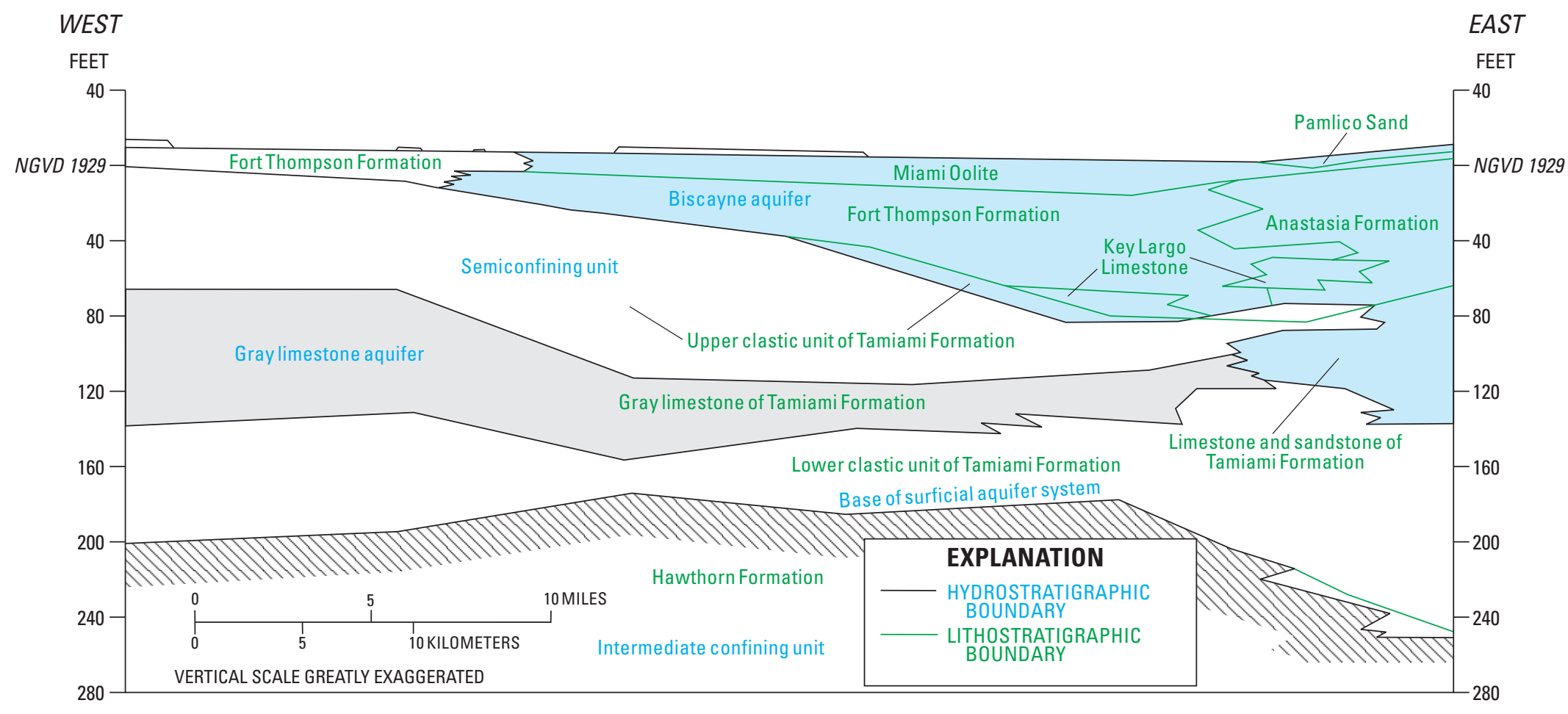

Figure 6. Geologic formations, aquifers, and confining units of the surficial aquifer system in central Miami-Dade County. From Fish and Stewart (1991). 

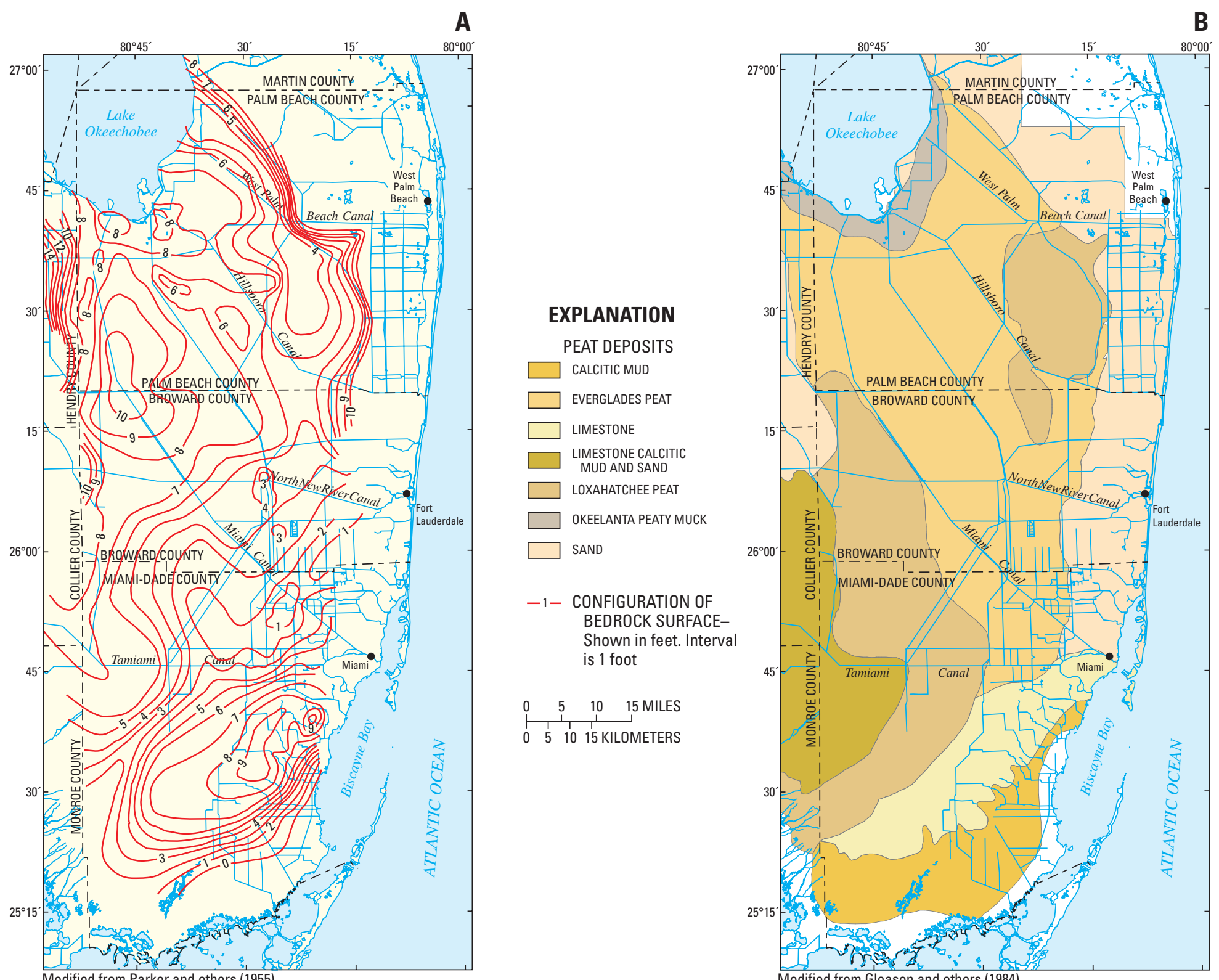

Figure 7. $(A)$ Configuration of bedrock surface underlying peat deposits and $(B)$ distribution of peat deposits in southeastern Florida. Modified from Parker and others (1955) and Gleason and others (1984). 
Spackman, 1984; Jones, 1948), Holocene peat deposits were formed in freshwater marsh areas in which the hydroperiod exceeded 270 days per year (Duever and others, 1994). Lengthy hydroperiods maintain anaerobic conditions that are needed to insure accumulation of plant vegetation and minimize dry season oxidation, consolidation, and compaction of organic sediments.

Prior to development of the modern Everglades Agricultural Area, peat deposits ranged from 6 to $17 \mathrm{ft}$ thick (Stephens and Johnson, 1951). The stage level of surface water overlying these peat deposits ranged from 18 to $24 \mathrm{ft}$ near Lake Okeechobee. Peat deposits thinned where they extend southward and were reported to have been $2.5 \mathrm{ft}$ thick in the southern part of the Everglades (Gleason and others, 1984). In the northernmost part of the Everglades, a calcareous marl sequence separates the peat deposit from underlying limestone bedrock; freshwater marl is considered indicative of a shorter hydroperiod that cannot support peat accumulation (Gleason and others,

1984). Drainage works in agricultural areas designed to control flooding south of the lake have contributed greatly to oxidation- and compaction-driven subsidence of peat deposits (fig. 8). Subsidence ranged from 3 to $9 \mathrm{ft}$ in the Everglades Agricultural Area and was as much as $3 \mathrm{ft}$ in nonirrigated areas to the south and southeast (Ingebritsen and others, 1999).

Hydroperiods characterized by lengthy flooding and anaerobic conditions supported the accumulation of dead plants into deposits of peat (Cohen and Spackman, 1984). Predevelopment peat deposits within the location of the modern Everglades Agricultural Area ranged from 6 to $17 \mathrm{ft}$ thick (Stephens and Johnson, 1951) with land-surface altitudes of 18 to $24 \mathrm{ft}$ near Lake Okeechobee (South Florida Water

Management District, 2003). The average thickness of peat deposits thinned to $2.5 \mathrm{ft}$ in the southern Everglades (Gleason and others, 1984). Near Fort Lauderdale along the North New River Canal in eastern Broward County (fig. 7, the subsidence of peat deposits lowered land-surface altitude as much as $5 \mathrm{ft}$ between 1915 and the early 1950s (Stephens, 1984).

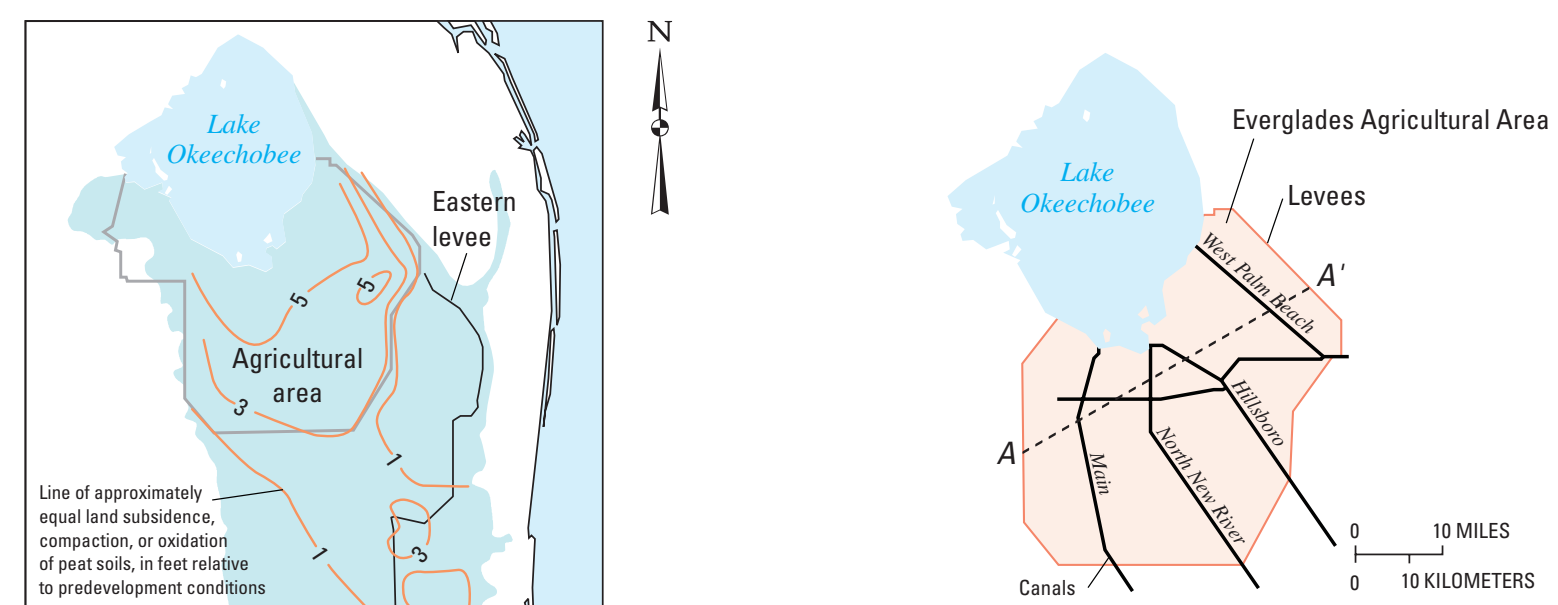

Figure 8. Everglades drainage conveyance features that contributed to a gradual loss of peat and peat soils through subsidence, compaction, and oxidation. Modified from Stephens and Johnson (1951) and Ingebritsen and others (1999).

The surficial aquifer system of southeastern Florida is wedge shaped, thickening eastward toward the Atlantic Ocean. The system ranges from less than $360 \mathrm{ft}$ thick in western Broward and north-central Palm Beach Counties to greater than $400 \mathrm{ft}$ thick in coastal areas of northeastern Broward and southeastern Palm Beach Counties (fig. 9). In the Miami-Dade County area, the surficial aquifer system ranges from 140 to $240 \mathrm{ft}$ thick. 
The surficial aquifer system (Fish, 1988; Fish and Stewart, 1991) comprises a sequence of highly permeable limestone, quartz sand, shell, and terrigeneous mudstone of Pliocene to Holocene age. The sand content of the surficial aquifer system is high to the north and east; limestone and sandstone are more prominent to the south and west. Lithologic units that compose the surficial aquifer system are thin and lens like, and the complete stratigraphic sequence is not present at any one place. Some rock units interfinger, whereas other units are considered lateral equivalents of one another.

The surficial aquifer system has been divided into separate aquifers and semiconfining (leaky) units of quartz sand, terrigeneous mudstone, and limestone (Fish, 1988; Fish and Stewart, 1991). The Fort Thompson Formation, Anastasia Formation, and Key Largo Limestone yield the most water and constitute the prolific Biscayne aquifer (fig. 6). Defined as a sole-source aquifer (U.S. Environmental Protection Agency, 1979), the karstic Biscayne aquifer comprises highly permeable limestone and less-permeable sandstone and sand of Pleistocene and late Pliocene age. The Biscayne aquifer generally is considered to extend northward from southeastern Monroe County and southernmost Miami-Dade County into southern Palm Beach County. The Miami Limestone, Pamlico Sand, Fort Thompson Formation, Anastasia Formation, and Key Largo Limestone make up the Biscayne aquifer in Miami-Dade and Broward Counties. In southern Palm Beach County, the Anastasia and Fort

Thompson Formations compose the Biscayne aquifer and are considered equivalent to the "cavity-riddled" zone (Fischer, 1980) or "zone of secondary permeability" (Swayze and Miller, 1984). The Biscayne aquifer does not extend into central and northern Palm Beach County; however, a moderately to highly transmissive limestone sequence forms its lateral hydrogeologic equivalent and has been defined as the non-Biscayne production zone (Shine and others, 1989).

In western Miami-Dade County, the Biscayne aquifer is characterized as an eogenic karst limestone containing diffuse carbonate comprising small scale-scale vugs and matrix, interlayered with carbonate rock units forming conduit-type, preferential flow zones. These flow zones are formed by large touching vugs; pervasive solution features seem to extend over a area (Cunningham and others, 2003). Karst features that include sinkholes and caves have been documented in Miami-Dade County along the Atlantic Coastal Ridge extending southward from south Miami to Everglades National Park (Cressler, 1993). Parker and others (1955, p. 269) have described cavernous permeability and solution holes within the Miami Limestone and Fort Thompson Formation that create turbulent flow conditions in some wells. Paleotopographic relief on karstic subaerial exposure surfaces (paleokarst) are well documented in the Lake Belt area of north-central Miami-Dade County (Cunningham and others, 2004). Although karst features have not been documented in Broward or Palm Beach Counties, the "cavity-riddled" zone (Fischer, 1980) is likely associated with karst dissolution.

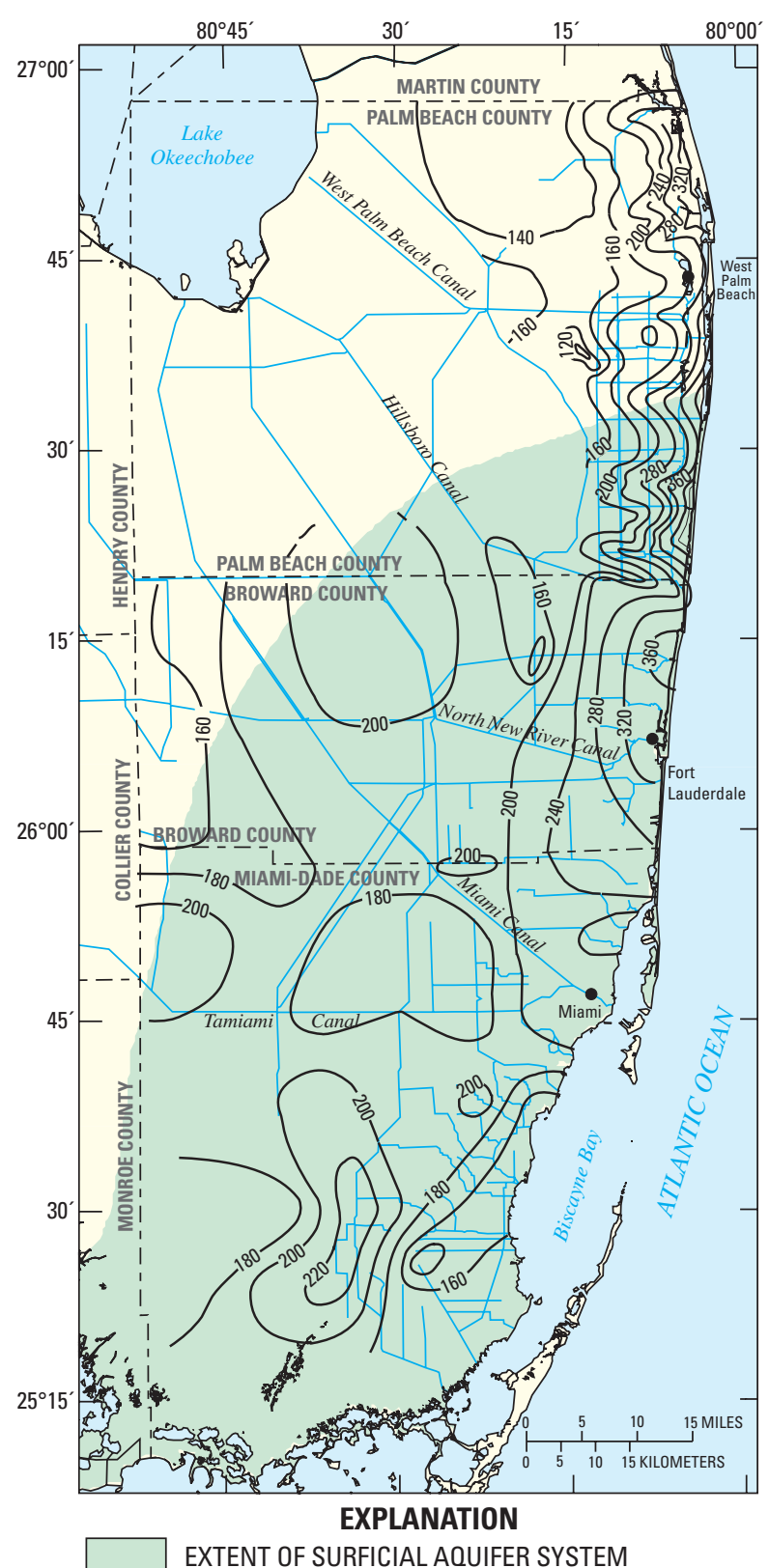

EXTENT OF SURFICIAL AQUIFER SYSTEM

-180 - STRUCTURE CONTOUR-Shows altitude of the base of the surficial aquifer system, in feet below NGVD 1929. Dashed where approximately located. Interval is 20 feet
Figure 9. Base and extent of the surficial aquifer system in southeastern Florida. Modified from Fish (1988), Shine and others (1989), and Fish and Stewart (1991). 
Permeability of the surficial aquifer system is highest in areas where the Biscayne aquifer has been subject to extensive dissolution. Transmissivity of limestonerich areas is greater than 1,600,000 ft'/d, but decreases to about 54,000 ft'/ where the aquifer mostly consists of sand (fig. 10). Because of high permeability and large withdrawals, the Biscayne aquifer is subject to contamination by saltwater intrusion. Yields of 1,000 to more than 7,000 gal/min are reported for some wells.

The intermediate confining unit separates the surficial aquifer system from the more deeply buried Floridan aquifer system —a 1,000-ft-thick sequence of poorly permeable carbonate rock, clay, clay-rich sand, and sand that form the Hawthorn Group (Miller, 1997, fig. 6.24). Permeable limestone and lesser dolomitic rocks compose the Floridan aquifer system, which mostly contains brackish to saline water in southeastern Florida. The Floridan aquifer system is not hydraulically connected to the Biscayne aquifer. Use of the Floridan aquifer system in Miami-Dade, Broward, and Palm Beach County is limited to aquifer storage and recovery (ASR), reverse osmosis, and wastewater injection within the deeply buried Boulder Zone.

\section{Hydrochemistry}

The regional quality of ground water within the surficial aquifer system can be characterized by the hydrochemical facies of the water and its dissolved-solids concentration. Hydrochemical facies are determined by the dominant anions and cations in the ground water. For example, calcium bicarbonate water is one in which calcium ions are more than 50 percent of the total cations in the water, and bicarbonate ions are more than 50 percent of the anions.

Calcium bicarbonate waters are dominant in shallow parts of the surficial aquifer system in most of the tri-county area (fig. 11). In western Miami-Dade and Palm Beach Counties, however, calcium bicarbonate waters are limited in extent, and mixed ion (sodium bicarbonate) and sodium chloride water occur at shallow depths. This combination is attributable to lower permeability within rocks that comprise the surficial aquifer system and the incomplete flushing of relict seawater by meteoric water. Mixed ion (sodium bicarbonate) and sodium chloride waters, however, mostly dominate deeper parts of the surficial aquifer system. A general comparison of the distribution of hydrochemical facies and permeability within the surficial aquifer system (fig. 11) suggests that calcium bicarbonate waters tend to have the greatest vertical extent in areas where permeability is high. Sodium chloride water is also common along the coast where the surficial aquifer system contains seawater.

The specific conductance and concentration of dissolved chloride can be used in southeastern Florida to evaluate the relative quality of ground water. Specific conductance is a measure of the ability of water to carry an electric current and provides an approximate estimate of the quantity of dissolved ions in solution.

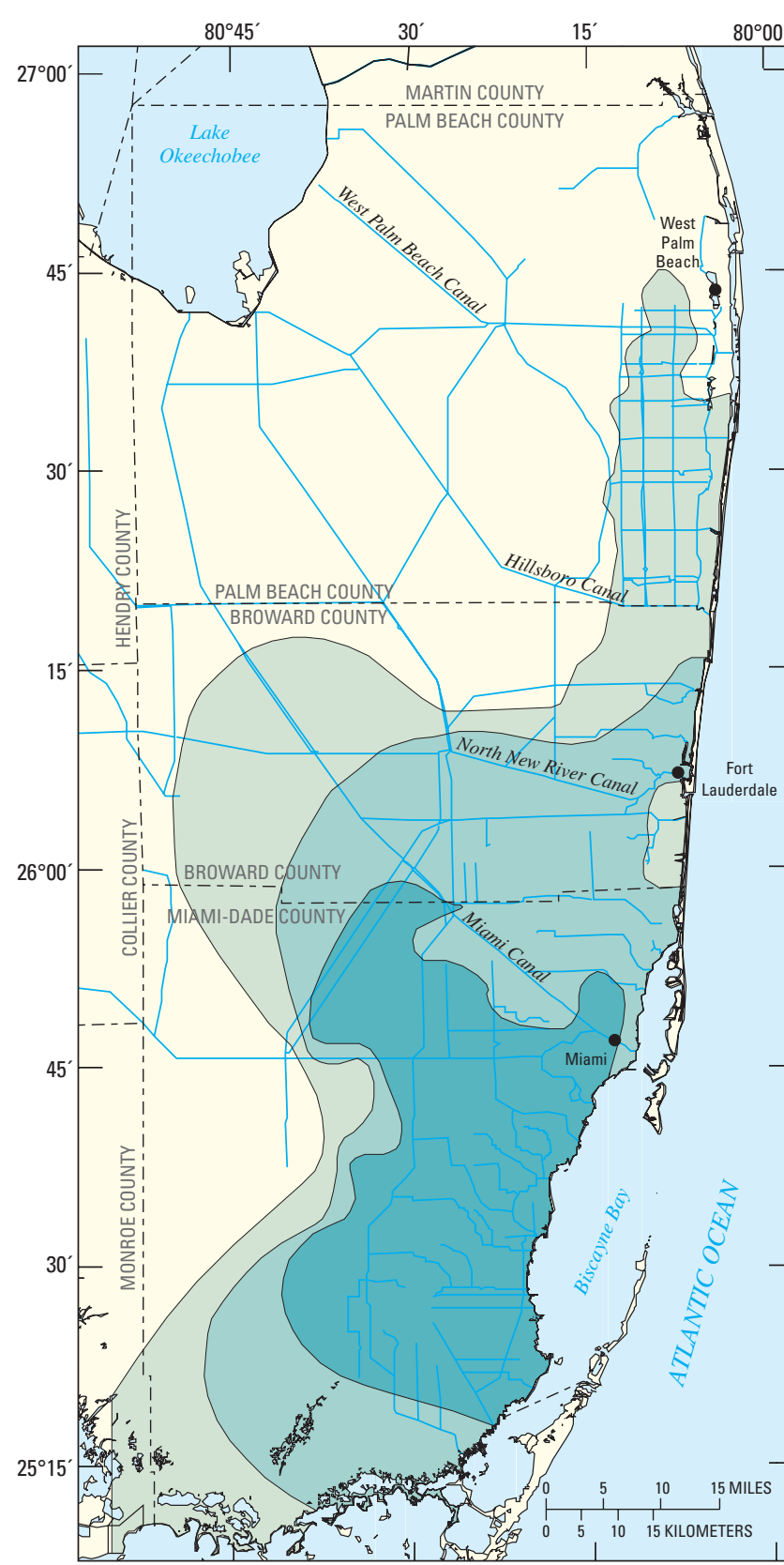

Figure 10. Distribution of transmissivity within the surficial aquifer system in southeastern Florida. Modified from Fish (1988), Shine and others (1989), and Fish and Stewart (1991).

\section{EXPLANATION}

TRANSMISSIVITY, IN FEE SOUARED PER DAY

\section{$<300,000$}

300,000 to $1,000,000$

$>1,000,000$ 


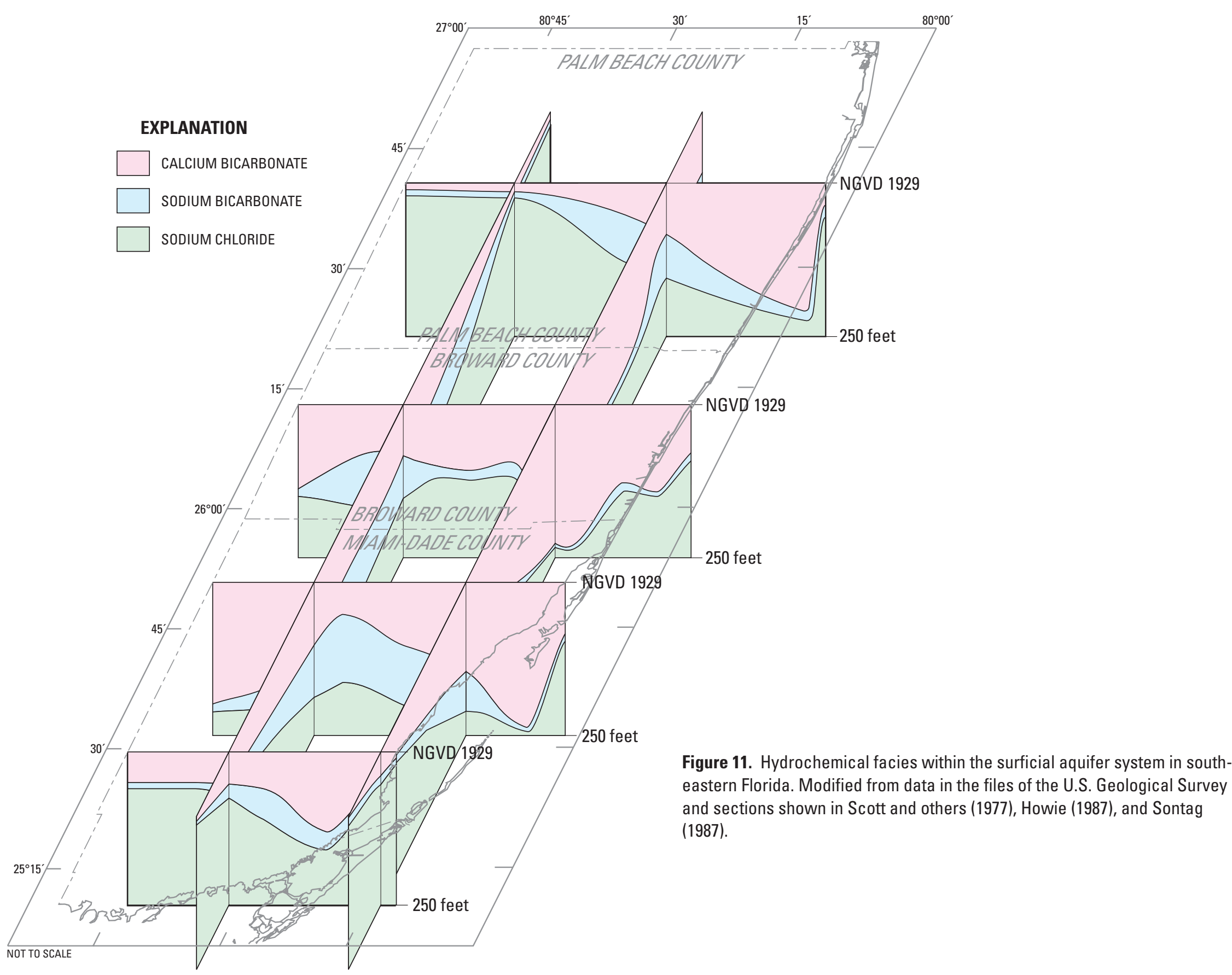




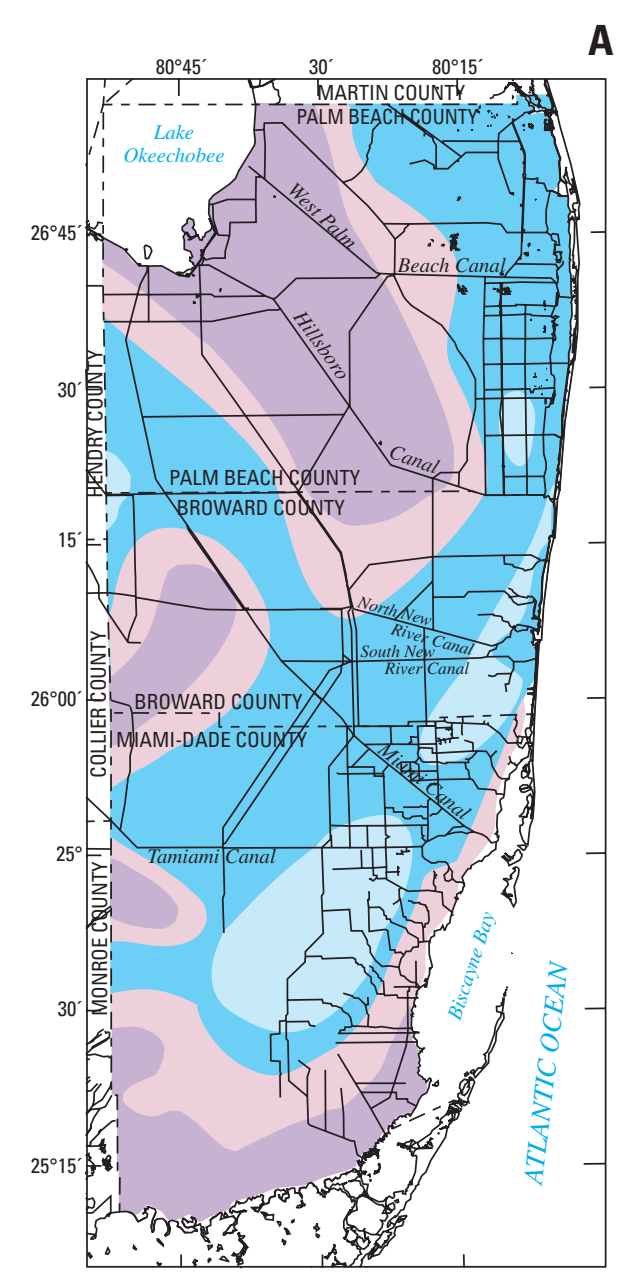

Figure 12. Distribution of dissolved chloride and specific conductance at depths of (A) 50, (B) 100, and (C) 150 feet within the surficial aquifer system in southeastern Florida. Modified from Scott and others (1977). Howie (1987), Sonntag (1987), and data in the files of the U.S. Geological Survey.
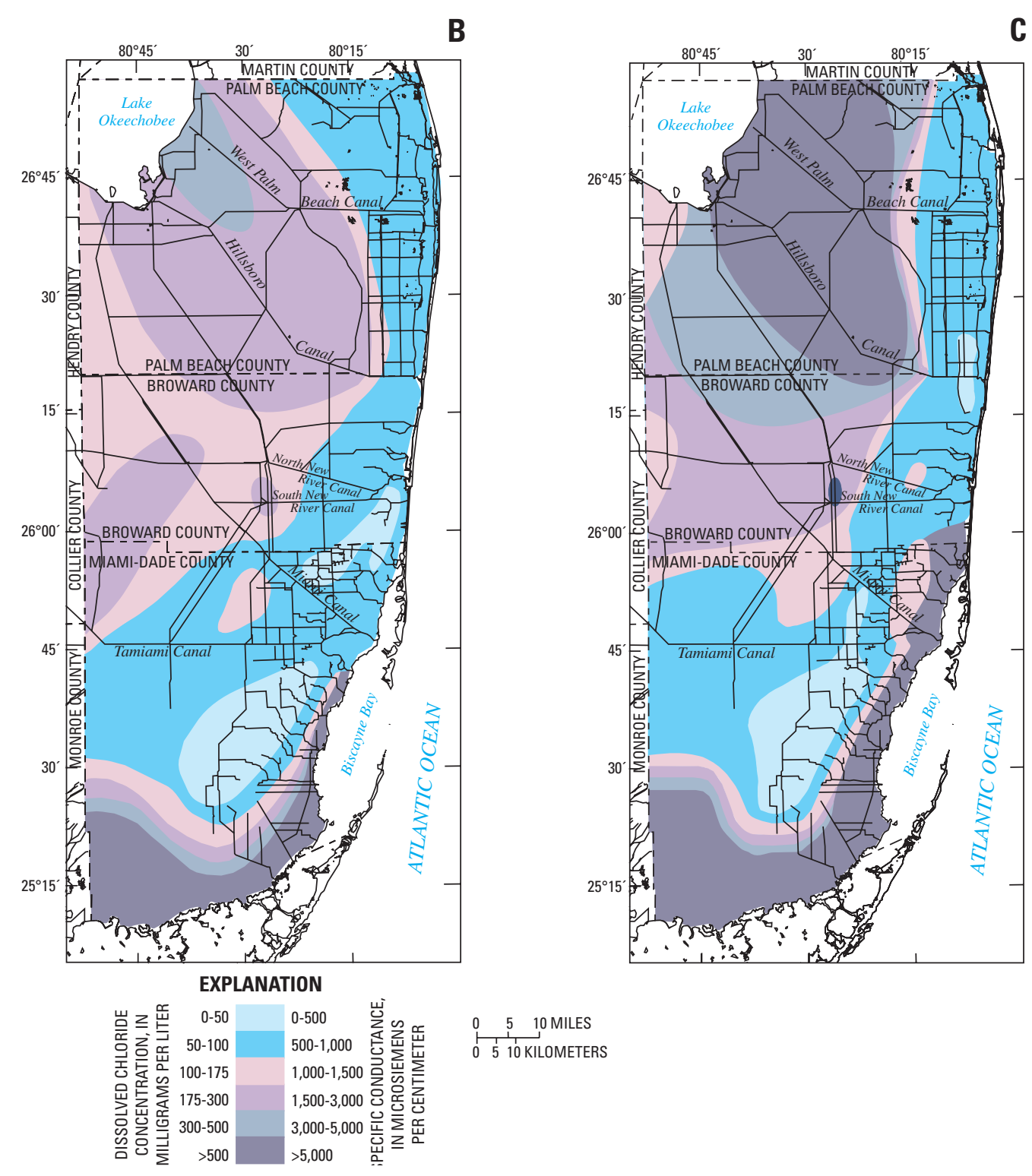

$5 \quad 10$ MILES
Dissolved chlorides can be used to provide insight to the potable nature of ground water. The standard for potable water set forth by the U.S. Environmental Protection Agency (1999) is $250 \mathrm{mg} / \mathrm{L}$.
Specific conductance has been mapped at selected depths in the tri-county area (fig. 12) to determine where: (1) potable water and relict seawater exist, and (2) seawater has intruded landward (Howie, 1987; Sonntag, 1987). Specific 
conductance (and chloride concentration) is generally less than $1,000 \mu \mathrm{S} / \mathrm{cm}$ in areas with high transmissivity, except along the coast where the surficial aquifer system has been subject to saltwater intrusion. Low specific conductance within the surficial aquifer system is reported in eastern Palm Beach County, eastern Broward County, and much of central Miami-Dade County. With the exception of areas where saltwater intrusion has occurred, such as coastal Miami-Dade County, high specific conductance measurements are considered representative of relict seawater. Relict seawater is inferred to underlie an area that extends southeast of Lake Okeechobee into southwestern Broward County.

\section{Changes in Land Use and Population Trends}

Land-use and land-cover change in southeastern Florida parallels $20^{\text {th }}$ century anthropogenic change observed on a global scale. Land-use and land-cover transformation occurs through a successive conversion of one land class to another use-forests are cleared and wetlands are drained to promote agricultural development, and cultivated lands are converted for urban use in response to an accompanying increase in population (Turner and Meyer, 1994).

Urban and agricultural growth and accompanying land-use change in southeastern Florida has greatly affected the ecological health and stability of the Everglades and Biscayne Bay ecosystems. Land-cover and population data illustrate changes in land use and population density in response to cultivation of drained wetlands and the southward expansion of the Florida East Coast Railroad, the 1920s land boom and subsequent bust, post-World War II development and redevelopment, and large-scale immigration. Population growth has been extraordinarily rapid - in 1900 southeastern Florida included a few small towns with a population of 3,592 people. Today, urban areas of southeastern Florida have grown to more than 5 million residents.

In the early part of the $20^{\text {th }}$ century, southern Florida was a largely pristine environment of marsh wetlands, sawgrass plains, swamp forests and wet prairies

(fig. 13A). Drainage canals were under construction, but the Everglades had not yet been drained. The Florida East Coast Railroad was completed as far south as Miami. In 1900, Miami and Coconut Grove had populations of 1,681 and 850 people, respectively (fig. 13B). Dania became the first incorporated Broward community in 1904, followed by Pompano Beach in 1908, and Fort Lauderdale in 1911 (fig. 13C).

The transfer of Federal land to the State initiated the "land boom" era from 1903 to 1926 , signaled by the construction and completion of the primary drainage canals. The conversion of drained wetlands for tropical farm products, however, proved to be far more difficult than that which had been promoted by optimistic land sales companies and hopeful State officials (McNally, 1999). Efforts to cultivate the southern rim of Lake Okeechobee fell short of expectations due to difficulties associated with clearing land; infertile, copper-deficient muck soils; oxidation and compaction of peat soils; and dry-season muck fires. Cultivation of drained areas proved to be more successful along inland areas west of the Atlantic Coastal Ridge, especially near Pompano Beach (fig. 13C).

Inherent design flaws associated with the "Wright drainage plan" (U.S. Congress, 1911; Mead and others, 1912), failure to complete proposed structural improvements outlined in the "Randolph drainage plan" (U.S. Congress, 1913), inadequate funding, and catastrophic climatic events all helped slow the progress of agricultural development during the 1920s (McNally, 1999). Shoreline development during the 1920s resulted in modification of the barrier islands separating Biscayne Bay from the Atlantic Ocean due to construction of bridges, coastal channels, shoreline bulkheading, development of artificial islands, and other landfill activities (Cantillo and others, 2000). Urban and agricultural development activities were interrupted considerably by the 1926 and 1928 hurricanes, which devastated Miami, West Palm Beach, flooded the city of Hollywood, damaged structures in Fort Lauderdale, and resulted in the death of more than 2,000 workers south of Lake Okeechobee.

Economic development largely stalled during the 1930s but was followed by a period of recovery with the end of the Great Depression. Numerous military air-training bases were constructed in the 1940s military in Miami-Dade and Broward Counties and were accompanied by the influx of military personnel who inhabited the area during World War II (fig. 14B).

During the 1950s and 1960s, Miami and Fort Lauderdale grew quickly into modern cities (fig. 14C). During that time, growth was not limited to the larger cities. Outlying municipalities expanded and new municipalities were established. From 1940 to 1960, the Fort Lauderdale population increased from about 18,000 to 84,000 people, the Hollywood population increased from about 6,200 to 35,200 people, and the Miami population increased from about 172,000 to more than 290,000 people (fig. 14D). Construction of inland flood protection levees in Broward County contributed to lower ground-water levels, making former cypress and pine forests areas ideal for development in the late 1950s.

A mid-1970s economic recession curtailed the rate of urban development, but development expanded further in the late 1970s and through the 1980s (fig. 15A). As the availability of coastal property and other land diminished, the construction of condominium high rises helped to attract retirees for year-round housing. Urban areas continued to encroach upon and replace agricultural areas. In Broward County, for example, most agricultural areas were displaced entirely by the late 1990s. The 1980s marked the large-scale influx of immigrants from Latin and South America, which continued unabated into the 21 st century (fig. 15D). By the close of the $20^{\text {th }}$ century, approximately 65 percent of the historic Everglades area was permanently lost to agricultural and urban development (fig. 15A), with the greatest loss of freshwater marsh areas having occurred in the Everglades Agricultural Area south of Lake Okeechobee (fig. 1) 

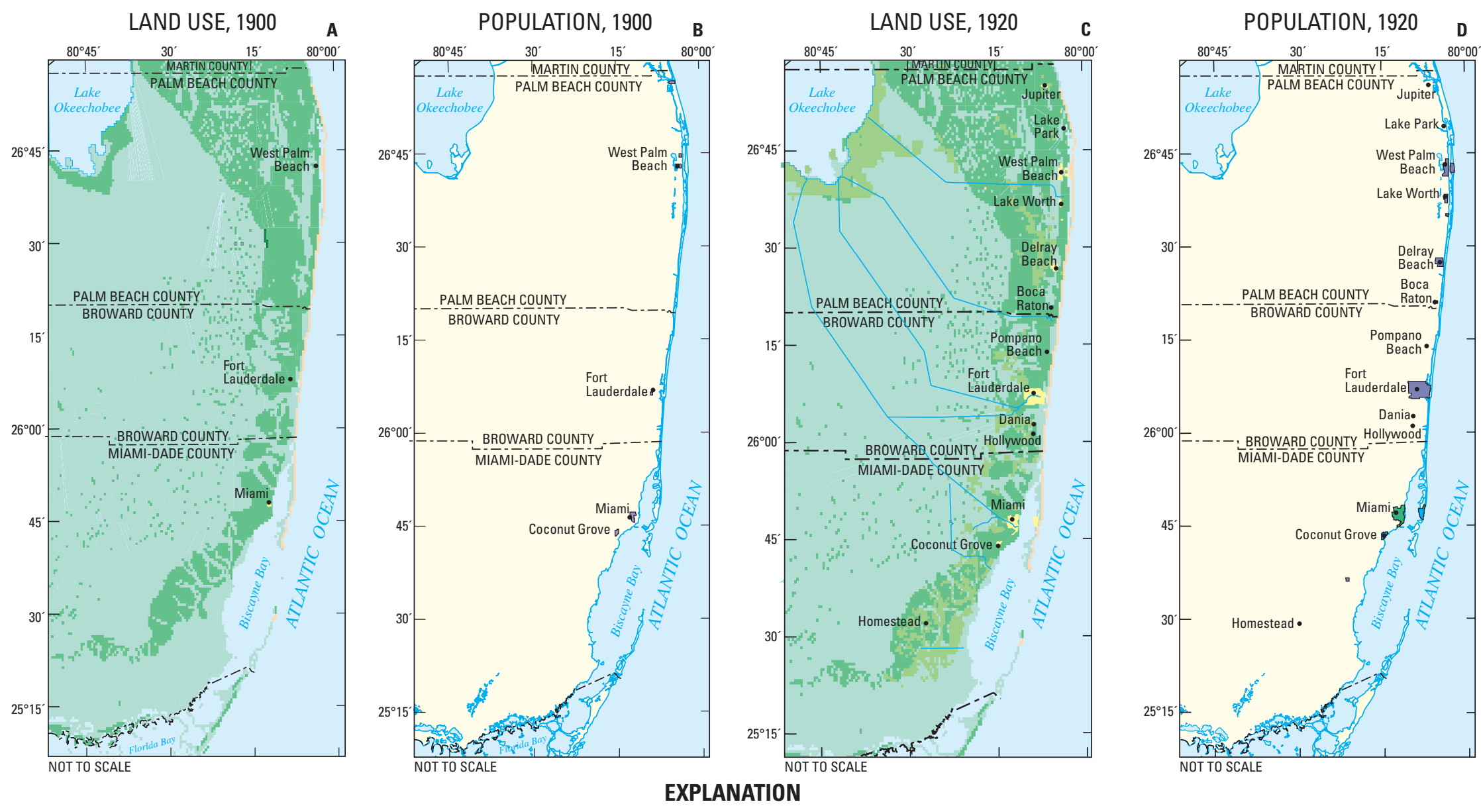

$\begin{array}{lll} & \text { LAND USE } & \text { POPULATION DISTRIBUTION } \\ \square \text { WETLANDS } & \square \text { OPEN WATER } & \square \text { 26,001 to 43,000 } \\ \square \text { BARREN LAND } & \square \text { AGRICULTURAL } & \text { 16,001 to 26,000 } \\ \square \text { UPLAND FOREST } & \square \text { URBAN AND BUILT-UP } & \square \text { 16,000 or Less }\end{array}$

Figure 13. Land-use conditions and population in southeastern Florida during (A, B) 1900 and (C, D) 1920. Compiled from Broward County Department of Land Use; Florida Department of State; Historical Museum of Southern Florida; Miami-Dade Department of Planning and Zoning; Palm Beach County Department of Planning, Zoning and Building; University of Florida; University of Miami; and U.S. Geological Survey topographic map collections. More details are presented in the "Sources of Land-Use and Population Information" section of this report. 

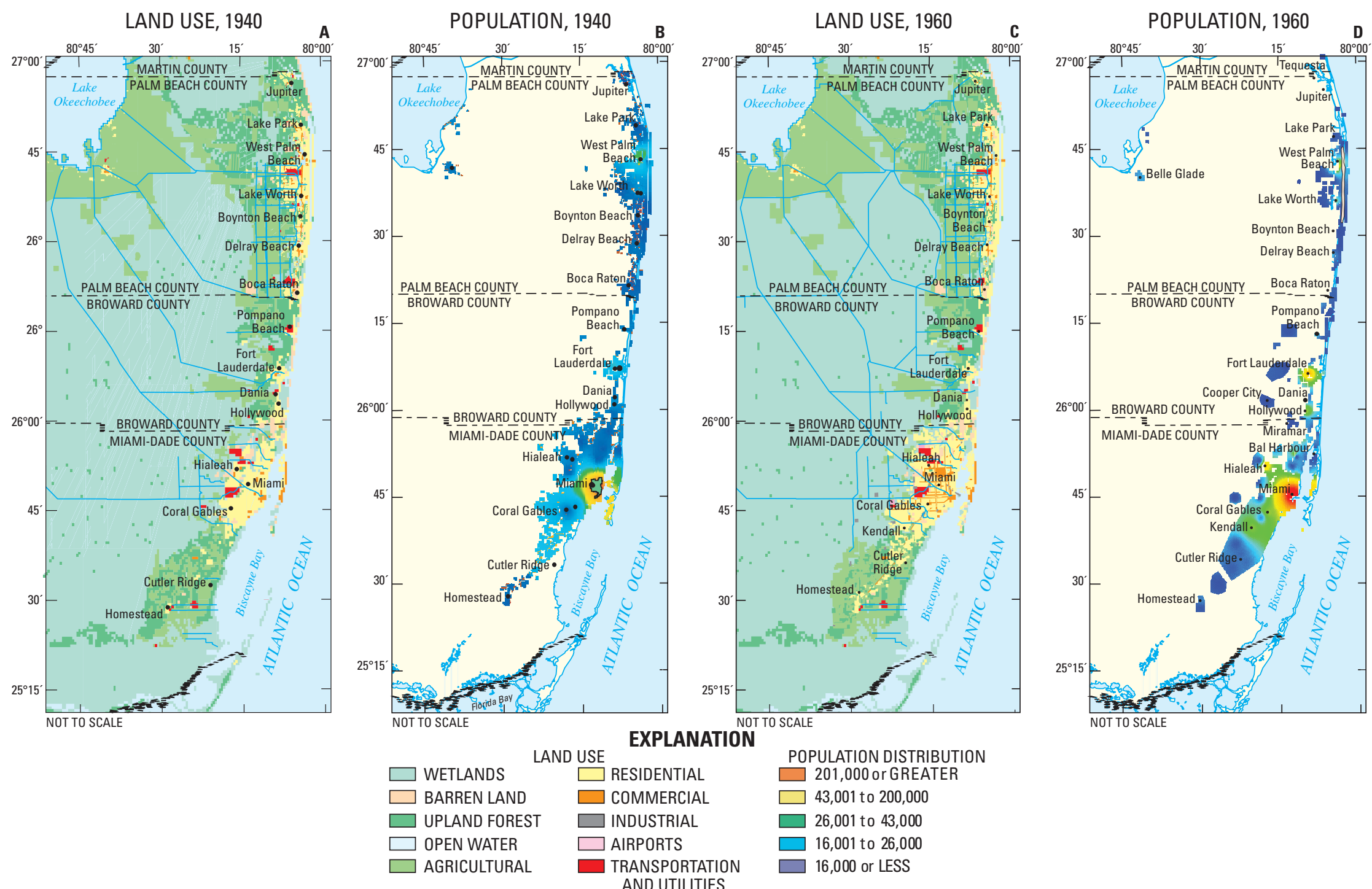

NOT TO SCALE

Figure 14. Land-use conditions and population in southeastern Florida during (A, B) 1940 and (C, D) 1960. The population density distribution for 1940 is partly based on a poorly defined land-use data set that outlines the extent of residential areas. At first glance, its comparison with the 1960 population density falsely implies that the population declined in southern Florida, paralleling an apparent reduction in the extent of residential areas. A closer examination of these maps reveals population density has increased, further substantiated by figure 2. Compiled from Broward County Department of Land Use; Florida Department of State; Historical Museum of Southern Florida; Miami-Dade Department of Planning and Zoning; Palm Beach County Department of Planning, Zoning and Building; University of Florida; University of Miami; and U.S.

Geological Survey topographic map collections. More details are presented in the "Sources of Land-Use and Population Information" section of this report. 

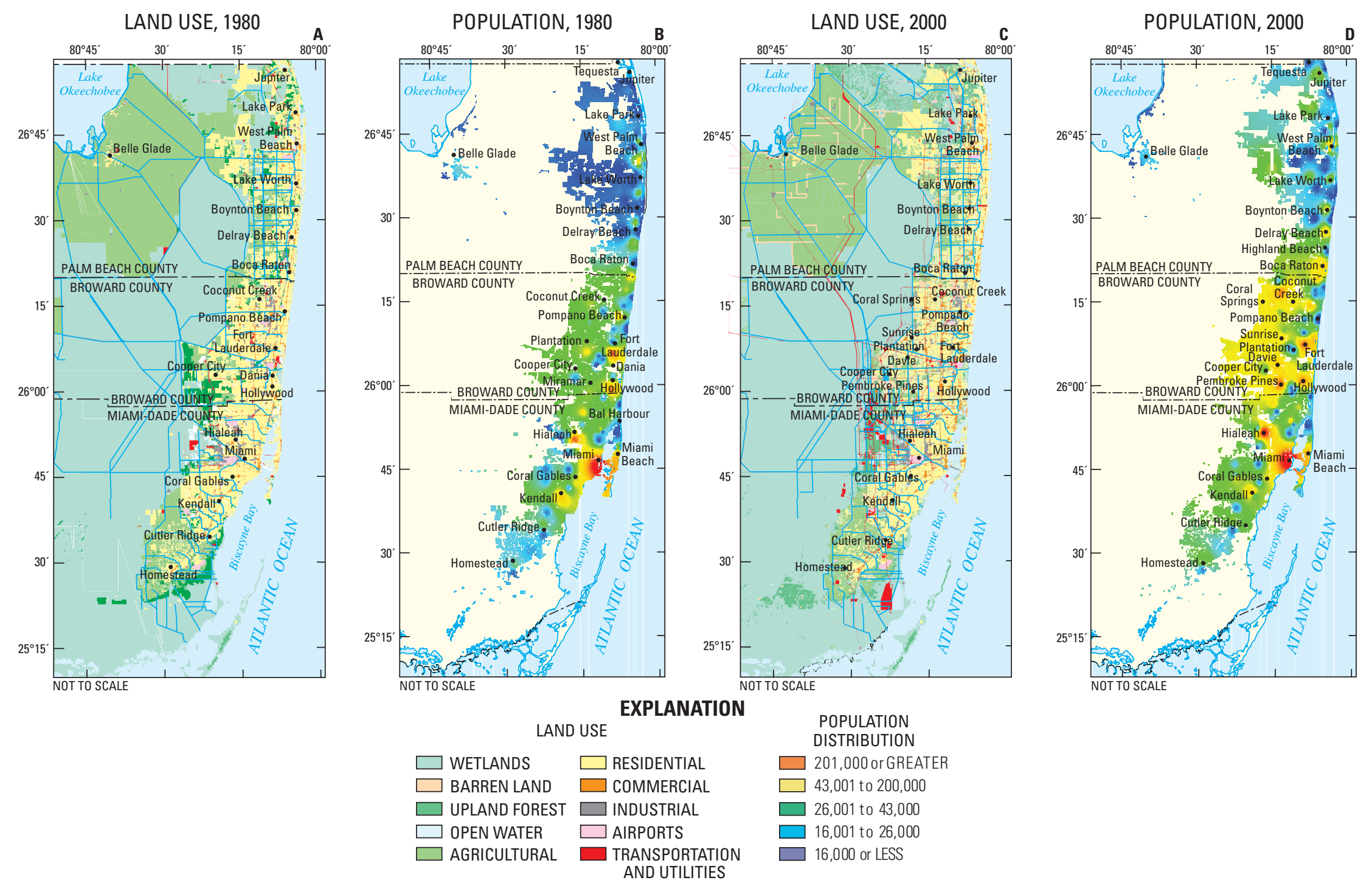

LAND USE

$\begin{array}{lll}\square \text { WETLANDS } & \square \text { RESIDENTIAL } & \square 201,000 \text { or GREATER } \\ \square \text { BARREN LAND } & \square \text { COMMERCIAL } & \square 33,001 \text { to } 200,000 \\ \square \text { UPLAND FOREST } & \square \text { INDUSTRIAL } & \square 26,001 \text { to } 43,000 \\ \square \text { OPEN WATER } & \square \text { ARPPORTS } & \square 16,001 \text { to } 26,000 \\ \square \text { AGRICULTURAL } & \square \text { TRANSPORTATION } & \text { AND UTILITIES }\end{array}$

Figure 15. Land-use conditions and population in southeastern Florida during (A,B) 1980 and (C, D) 2000. Compiled from Broward County Department of Land Use; Florida Department of State; Historical Museum of Southern Florida; Miami-Dade Department of Planning and Zoning; Palm Beach County Department of Planning, Zoning and Building; University of Florida; University of Miami; and U.S. Geological Survey topographic map collections. More details are presented in the "Sources of Land-Use and Population Information" section of this report. 


\section{Water and Land Uses}

Total water use in Miami-Dade, Broward, and Palm Beach Counties increased from 875 to about 2,148 Mgal/d between 1965 and 2000, respectively (fig. 16). As the principal source of freshwater in southeastern Florida, the surficial aquifer system provided about 1,085 Mgal/d in 2000 to meet municipal, agricultural, recreational, industrial, and power-generation needs as shown in figure 17 (U.S. Geological Survey, 2004). Ground water is the principal source for public supply in southeastern Florida, because it is readily available and requires little treatment prior to distribution (Marella, 1992). Surface water also provides a substantial portion of the overall water supply in the tri-county area. In 2000, surface-water use totaled about $1,063 \mathrm{Mgal} / \mathrm{d}$ in the tri-county area, with most of this water used to satisfy agricultural needs in Palm Beach County (Marella, 1999). Public supply and agriculture generally have represented the major water-use categories for ground water in Palm Beach, Broward, and Miami-Dade Counties. The increase in water use for public supply and recreation reflects the growth of urban areas. Total water use for public supply increased about two and three-quarter times (316 to $882 \mathrm{Mgal} / \mathrm{d}$ ) between 1965 and 2000, respectively.

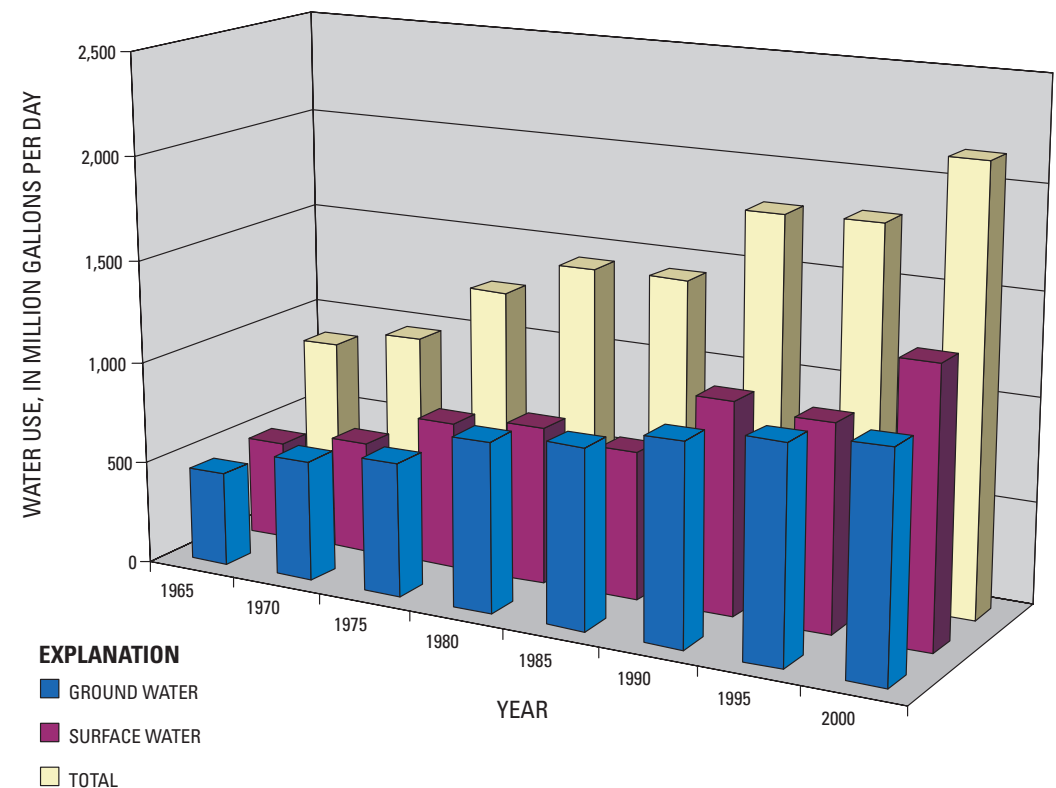

Figure 16. Water use in Miami-Dade, Broward, and Palm Beach Counties, 1965-2000. From U.S. Geological Survey (2004).

\section{Municipal Withdrawals}

Ground water is the principal source of water for municipal supply and the sole source of drinking water for about 3.8 million people in southeastern Florida. West Palm Beach is the only major municipality in southeastern Florida that uses surface water (obtained from nearby lakes) as its principal supply. In West Palm Beach, surface-water use increased from about $4 \mathrm{Mgal} / \mathrm{d}$ in 1930 to about $25 \mathrm{Mgal} / \mathrm{d}$ in 1995. Near Lake Okeechobee, several small rural communities use surface water for municipal supply.

Municipal withdrawals in Broward, Miami-Dade, and Palm Beach Counties have increased more than 11 fold over 65 years (figs. 18-20), from about $70 \mathrm{Mgal} / \mathrm{d}$ in 1930 to about $790 \mathrm{Mgal} / \mathrm{d}$ in 1995 (table 1). Increased withdrawals from the surficial aquifer system have combined with substantial land-use changes to affect the balance between freshwater and saltwater in the ground-water flow system. In 1930, only three municipal well fields operated in southeastern Florida, withdrawing about $66 \mathrm{Mgal} / \mathrm{d}$ (fig. 18); surface water supplied about $4 \mathrm{Mgal} / \mathrm{d}$ to West Palm Beach. By 1965, withdrawals from 41 well fields in the tri-county area exceeded $348 \mathrm{Mgal} / \mathrm{d}$ (fig. 19). Thirty years later (1995), 68 well fields withdrew about $790 \mathrm{Mgal} / \mathrm{d}$ (fig. 20). By 2020, municipal water demands are projected to reach 1,200 Mgal/d and serve 6 million people (South Florida Water Management District, 2000, p. 3).

The expansion of existing well fields and development of new municipal supply well fields have paralleled urban development. Temporal and spatial analyses of well-field locations and withdrawals during the $20^{\text {th }}$ century illustrate a westward shift in construction away from the coast in an effort to mitigate saltwater intrusion (figs. 18-20 and table 1). Recommendations are outlined in the Comprehensive Everglades Restoration Plan (U.S. Army Corps of Engineers and South Florida Water Management District, 1999) to further shift large well-field withdrawals from the coastal areas to western facilities. The relocation of existing or construction of new municipal well fields in western urban areas, however, is tempered by concern that they may adversely affect Everglades and water-conservation area ecosystems.

Centralized and decentralized well-field infrastructure development is evident in figures 18 to 20. In Miami-Dade County, a few large-capacity well fields withdraw the bulk of the municipal supply. Although 1995 ground-water withdrawals in Miami-Dade County were estimated to be about $394 \mathrm{Mgal} / \mathrm{d}$, only 14 well fields were operational (table 1). Five of these well fields withdrew more than $344 \mathrm{Mgal} / \mathrm{d}$ in 1995, which accounted for about 87 percent of all county withdrawals.

Municipalities of eastern Broward and Palm Beach Counties employ a decentralized system, illustrated by a wide distribution and numerous well fields withdrawing less than $10 \mathrm{Mgal} / \mathrm{d}$ (figs. 18-20). To help meet local supply needs, most of these municipalities developed their own water utilities and well fields. As municipalities became established and local populations grew, new well fields were constructed. In 


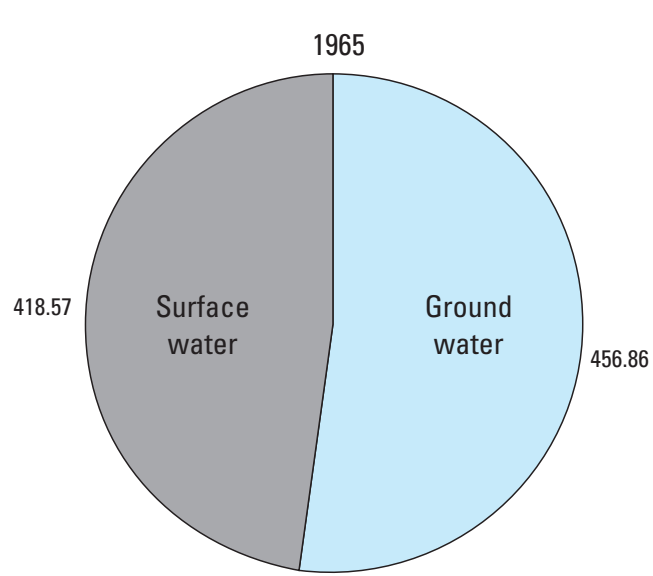

TOTAL WATER USE

TOTAL $=875.43$

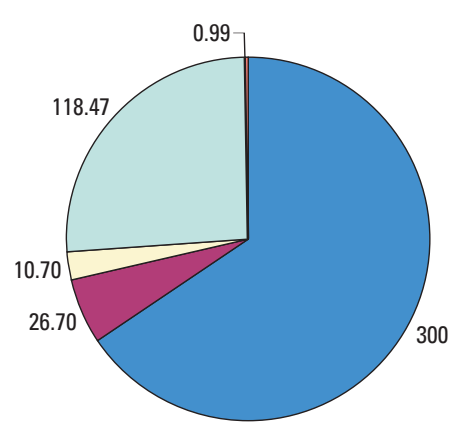

TOTAL $=456.86$

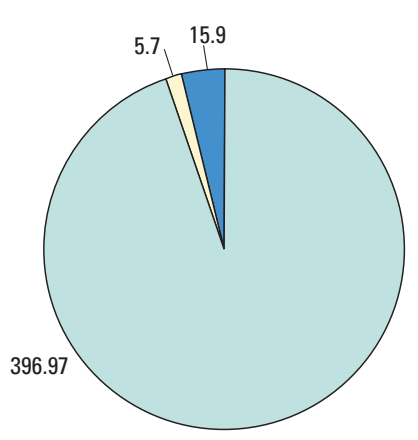

TOTAL $=418.57$

GROUND-WATER USE

\section{SURFACE-WATER USE}

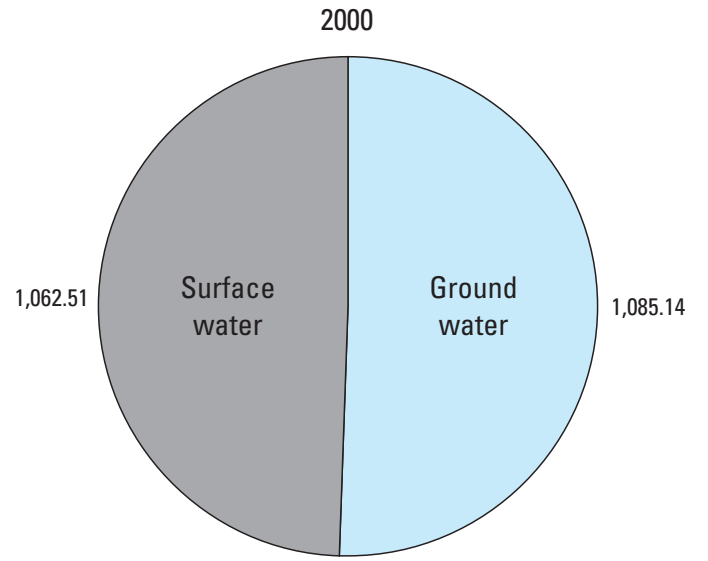

TOTAL $=2,147.65$
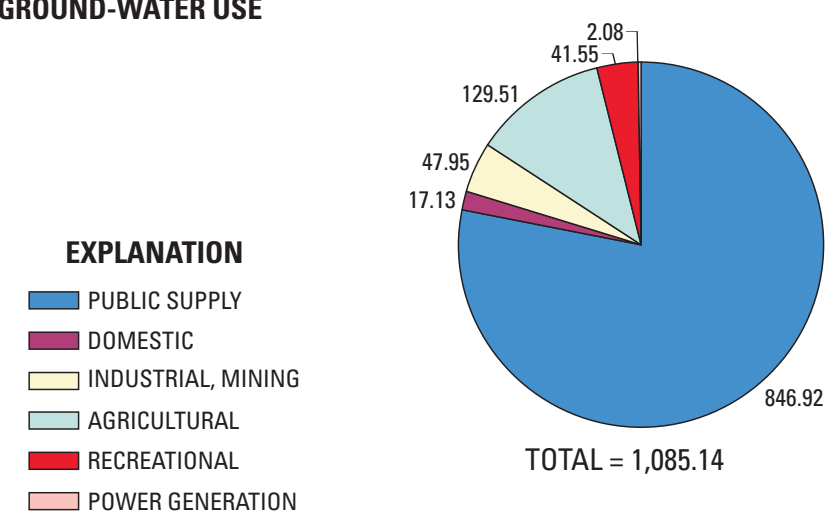

TOTAL $=1,085.14$

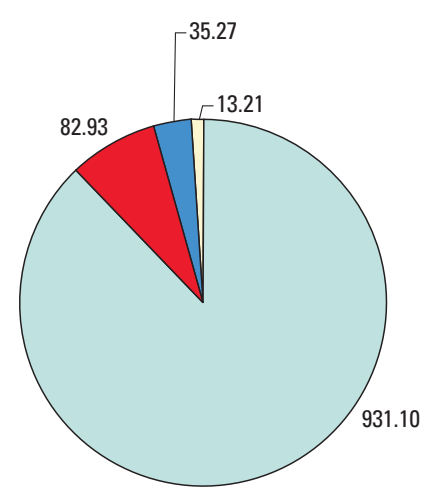

TOTAL $=1,062.51$
Figure 17. Ground- and surface-water uses in Miami-Dade, Broward, and Palm Beach Counties by category, 1965 and 1995. Values shown in million gallons per day. Derived from water-use data in the files of the U.S. Geological Survey. 


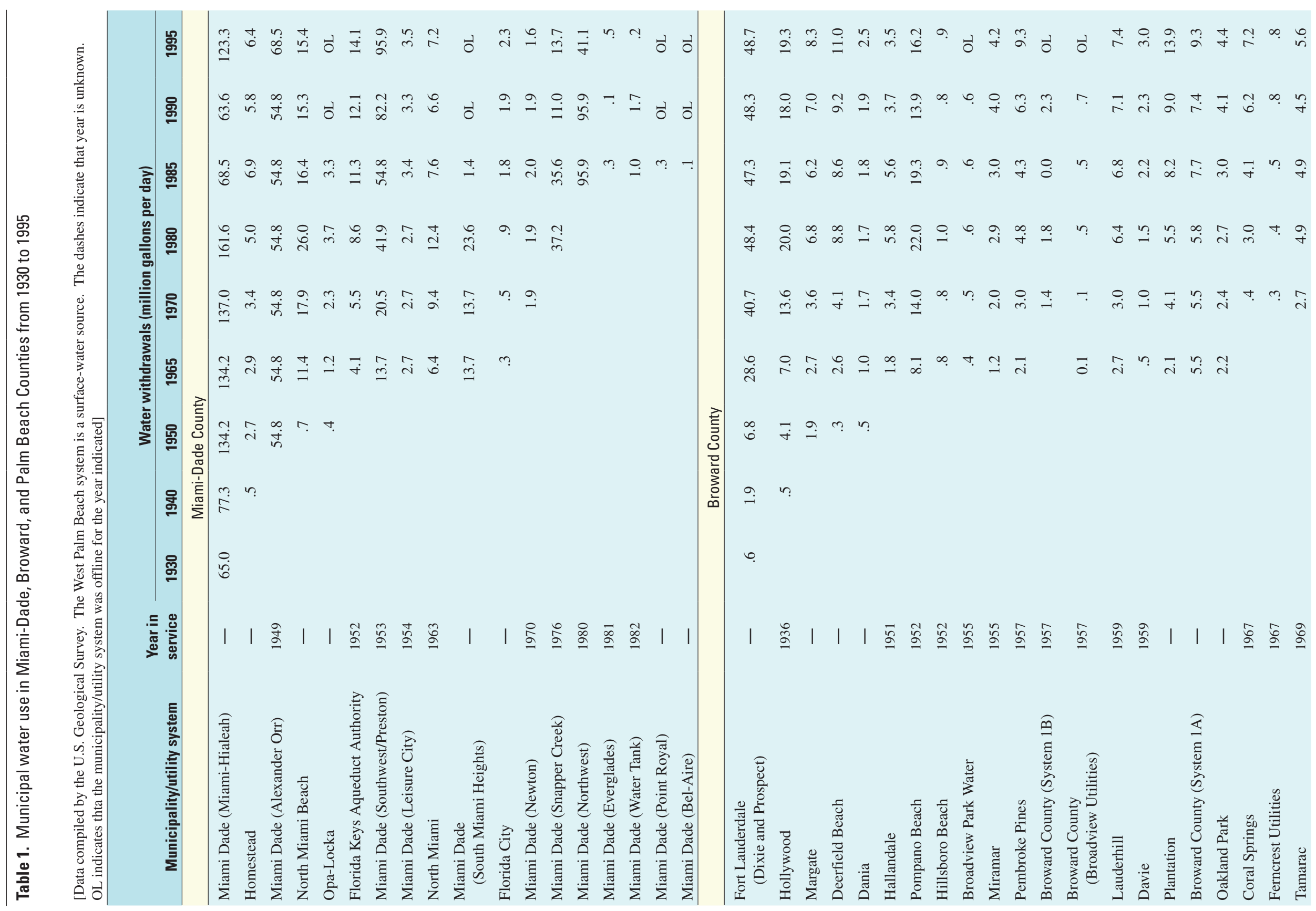




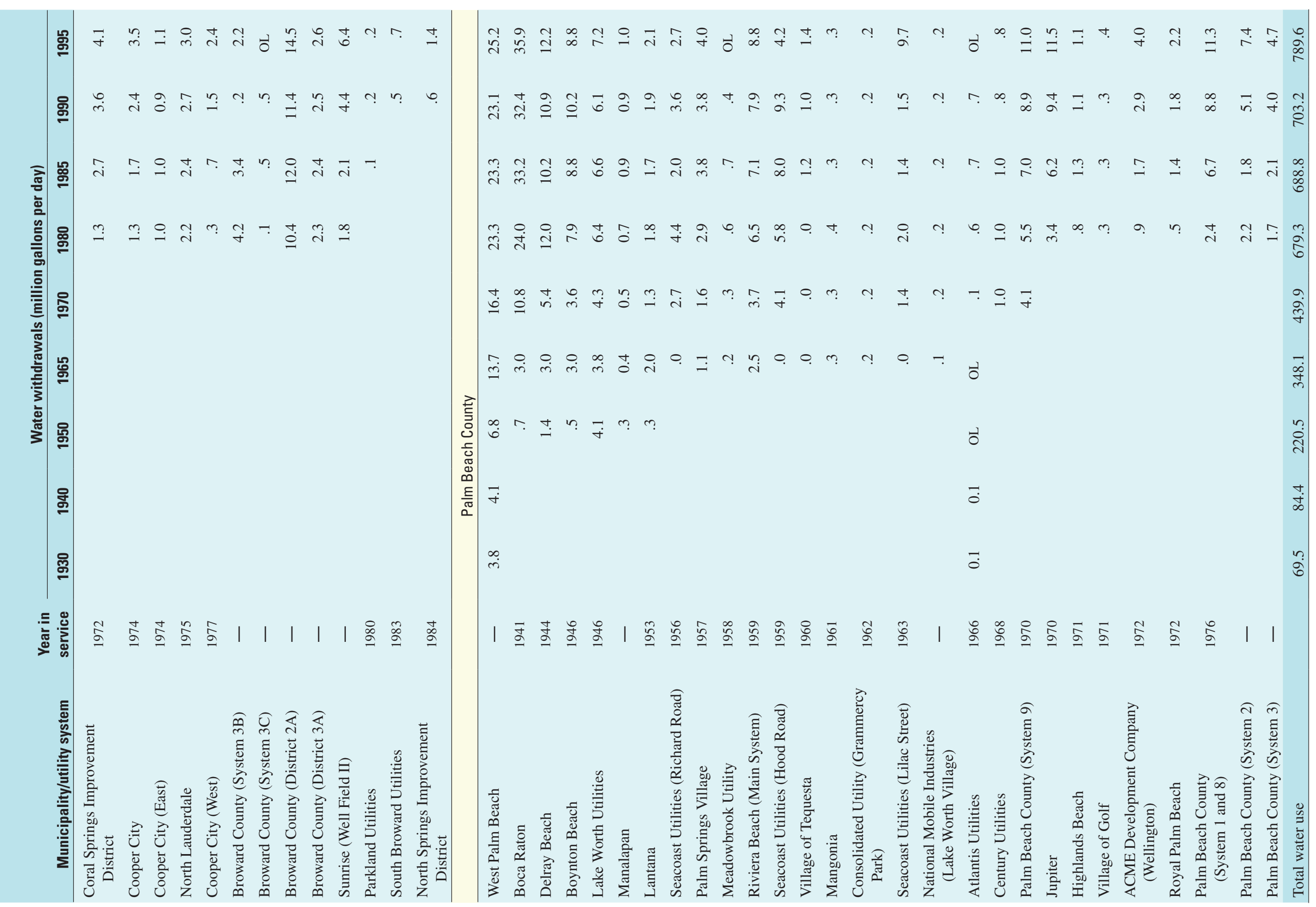



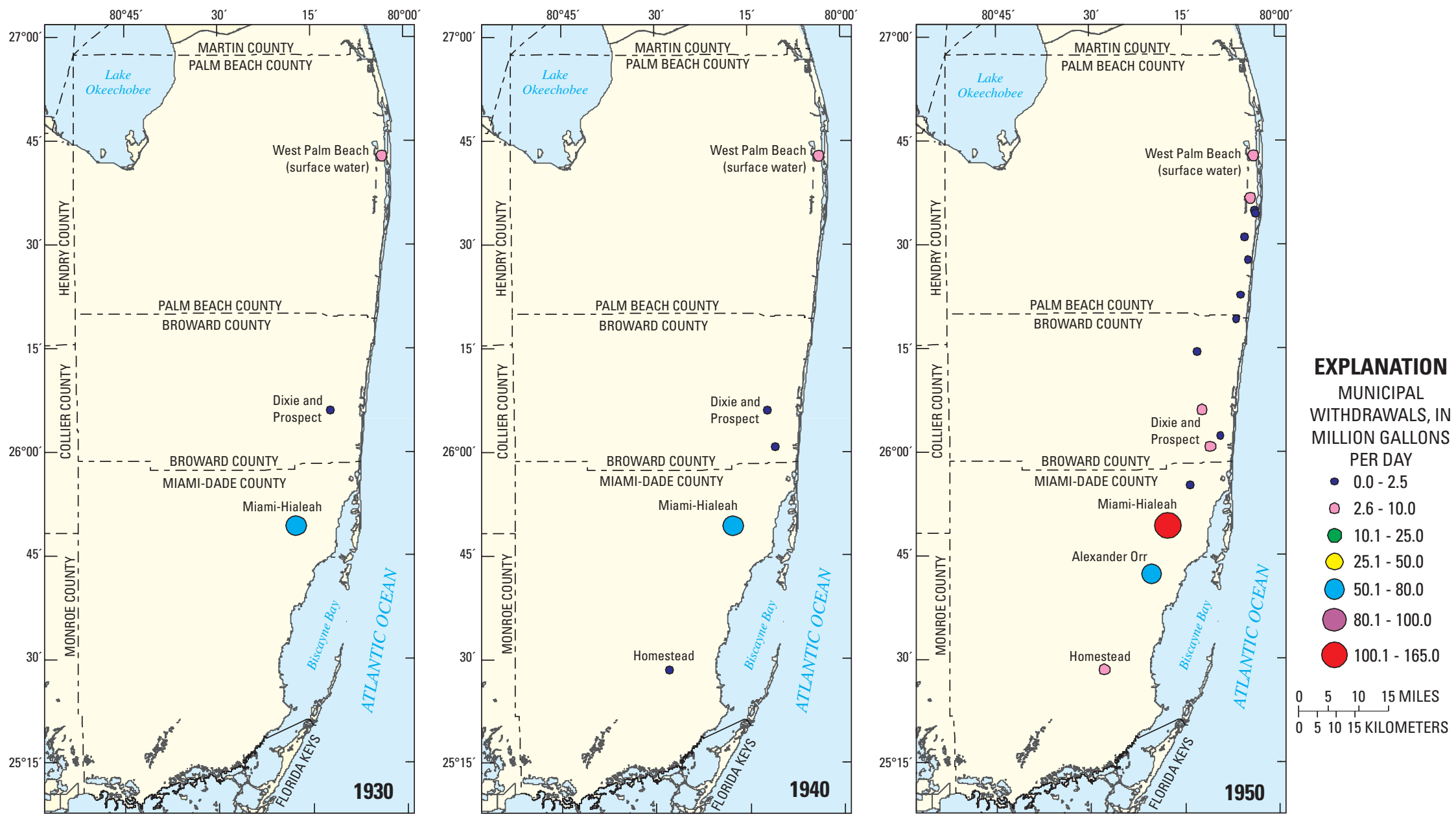

Figure 18. Municipal ground-water withdrawals in Miami-Dade, Broward, and Palm Beach Counties in 1930, 1940, and 1950. Derived from the files of the U.S. Geological Survey. 

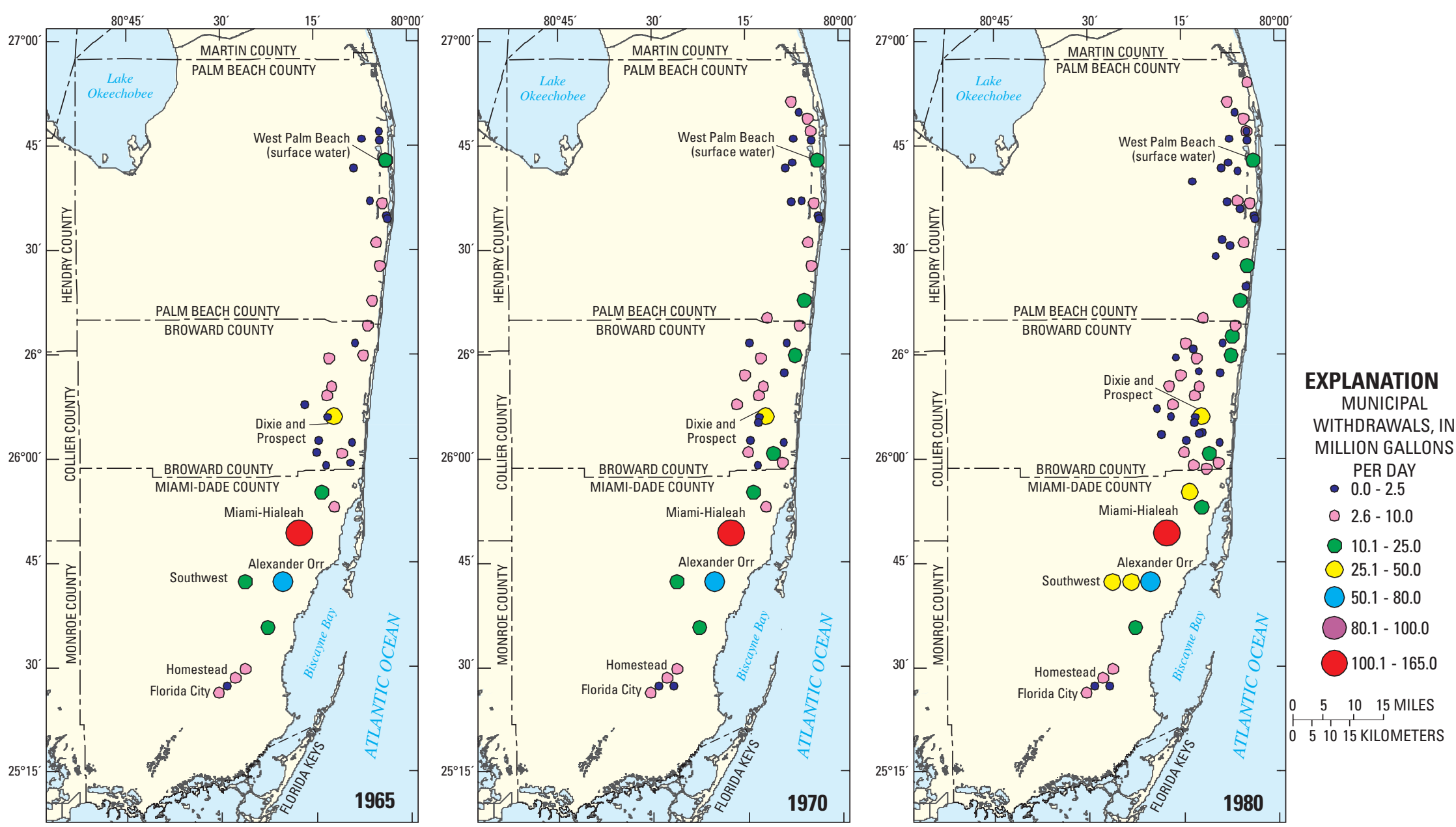

Figure 19. Municipal ground-water withdrawals in Miami-Dade, Broward, and Palm Beach Counties in 1965, 1970, and 1980. Derived from the files of the U.S. Geological Survey. 

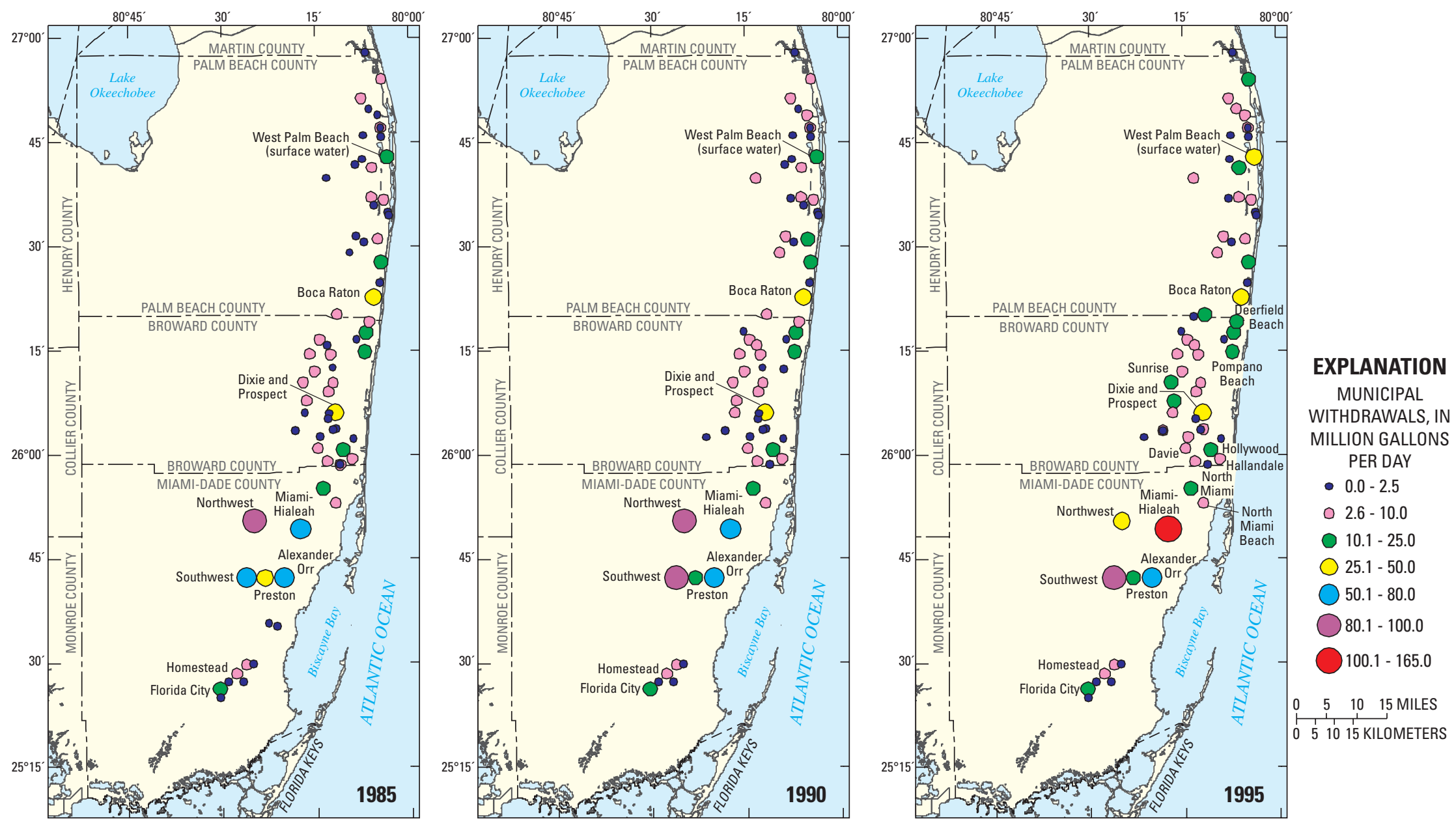

Figure 20. Municipal ground-water withdrawals in Miami-Dade, Broward, and Palm Beach Counties in 1985, 1990, and 1995. Derived from files of the U.S. Geological Survey. 
1995, 30 and 26 well fields were operational in Broward and Palm Beach Counties, respectively (table 1). Only the Fort Lauderdale Well Field (combination of the Dixie and Prospect Well Fields) in Broward County withdrew more than $20 \mathrm{Mgal} / \mathrm{d}$ of ground water. The Boca Raton Well Field in Palm Beach County withdrew more than $35 \mathrm{Mgal} / \mathrm{d}$ of ground water; however, the remaining well fields in the county withdrew less than $13 \mathrm{Mgal} / \mathrm{d}$ of ground water.

The Miami-Hialeah (Hialeah-Miami Springs), Northwest, and Alexander Orr, Southwest, and Preston (Snapper Creek) Well Fields in northeastern and east-central Miami-Dade County (fig. 20) are among the largest and most productive well fields in Florida. In 1995, these five well fields withdrew more than 125,000 Mgal (about $343 \mathrm{Mgal} / \mathrm{d}$ ) of ground water from the surficial aquifer system, accounting for about 87 percent of all the county well withdrawals. Despite historic problems associated with saltwater intrusion (Klein and Ratzlaff, 1989), the Miami-Hialeah Well Field has consistently served as a major source of water in southern Florida since its construction. About $162 \mathrm{Mgal} / \mathrm{d}$ of ground water were withdrawn from the HialeahMiami Springs Well Field in 1980. Well-field withdrawals diminished considerably (about $69 \mathrm{Mgal} / \mathrm{d}$ ) in 1985 due to low-grade toxic contamination reported in some supply wells; consequently, production was increased from the Northwest Well Field. In 1995, withdrawal rates from the Miami-Hialeah Well Field subsequently increased to about $123 \mathrm{Mgal} / \mathrm{d}$ (table 1). Smaller well fields located in southern Miami-Dade County serve the needs of Homestead, Florida City, and the Everglades. MiamiDade County also has exported ground-water supplies to the Florida Keys in Monroe County (Marella, 1999).

Saltwater intrusion has been a concern or has been detected near coastal well fields in Broward County, including Deerfield Beach, Hallandale, Pompano Beach, and the Davie Well Fields and has resulted in some local reduction or curtailment of production in selective wells. Additionally, saltwater contamination incidents have been of concern due their proximity to a number of well fields in Broward County including Fort Lauderdale (Dixie and Prospect), Broward County 2A and 3A, Plantation, and Sunrise.

Saltwater intrusion has been a concern near the Boca Raton Well Field in coastal southern Palm Beach County. Well fields have been constructed inland, and production along the coast has been reduced.

\section{Agricultural Water and Land Uses}

Surface and ground water are used to meet the needs of agricultural producers in Miami-Dade, Broward, and Palm Beach Counties. In Palm Beach County, agricultural users rely on surface water from Lake Okeechobee and canals for the cultivation of sugar cane and other field and row crops in the Everglades Agricultural Area (fig. 1). In this region, the underlying surficial aquifer system contains ground water that is highly mineralized, and the yield to wells is low (Miller, 1988). Regulatory release of surface water from Lake Okeechobee is made to major conveyance canals and agricultural canals including the L-10 borrow canal, Miami Canal, North New River Canal, and Hillsboro Canal. (fig. 3). In the Everglades Agricultural Area, growers have developed local canal systems to complement the regional conveyance systems; subirrigation systems are used to maintain desired water levels in fields used for sugar cane and vegetable crops. The same fields are used in rotation with rice crops, which are flooded with surface water during the summer.

In Miami-Dade County, ground water is the principal source of water for irrigation. Water is withdrawn from shallow uncased wells and conveyed using truckmounted pump and spray irrigation systems. Ground-water levels generally are maintained by closing control structures on the eastern edge of the Everglades Agricultural Area in Miami-Dade County. Most agricultural land in southern Miami-Dade County is used for field and row crops (truck crops), primarily tomatoes and small vegetables.

Once considered the Nation's principal source of winter bean, tomato, and pepper crops during the1920s and 1940s, the agricultural industry of Broward County has been largely displaced by residential and urban development (fig. 21). Broward County agricultural producers relied mostly on surface-water supplies between 1945 and 1960, subsequently converting to ground water as a primary source of water for irrigation.

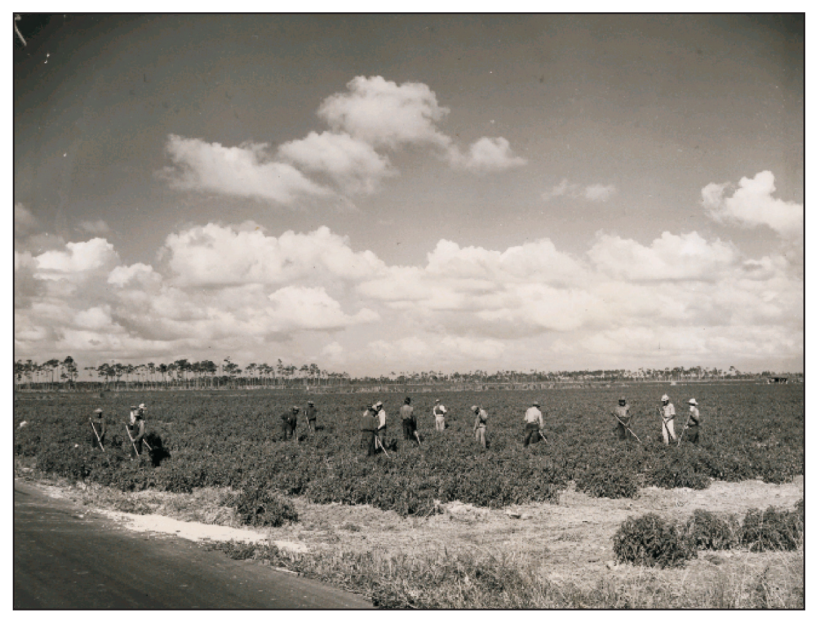

Figure 21. Workmen cultivating a field of tomatoes near Pompano Beach. Photo courtesy of the Historical Museum of Southern Florida, January 1942. 


\section{Land-Use Classification}

To better understand agricultural water use, the hierarchical Anderson land-use classification system (Anderson and others, 1976) was used in this study to categorize 1953, 1977, 1988, and 1995 agricultural land types from general to specificuse characterizations. Different land-use databases were developed separately with different classification schemes and contain inherent inconsistencies. For example, the 1953 land-use data (Costanza, 1975) were developed as part of an analysis of vegetative changes in the Everglades. Acquired from the USGS Geographic Information Retrieval and Analysis System (GIRAS), 1977 land-cover spatial data were compiled and redefined using aerial photography. The 1988 and 1995 land-use spatial data sets, prepared by the SFWMD, employ different classification schemes, use digital data obtained from county land-use planning maps, and include field and aerial photographic verification. The 1988 and 1995 data sets were classified by SFWMD using its own land-use coding system, patterned after the Florida Land Use and Cover Classification System used by the Florida Department of Transportation (1985).

As part of this analysis, agricultural land-use data were reassembled using Anderson categories in separate spatial data layers and redefined using a standard classification scheme. Where possible, crop types were grouped in the following major categories: improved pasture, sugar cane, citrus groves, grass, container ornamentals, tomatoes, and small vegetables.

\section{Methods Used to Estimate Water Use}

Agricultural consumptive water use can be estimated using direct or indirect methods. A direct method requires use of metering devices to accurately assess the amount of water applied to a cultivated field (R.L Marella and V.D. Singleton, U.S. Geological Survey, written commun., 1988). However, most agricultural areas in southeastern Florida are not metered. Therefore, the water-management districts in Florida indirectly estimate agricultural water use on the basis of crop acreage, a use coefficient, and crop irrigation model (Marella, 1999, p. 4). This indirect methodology was applied for 1953, 1977, 1988, and 1995 and used to develop multicounty spatial and temporal agricultural water-use maps (figs. $22 A$ and 22B). Agricultural water-use estimates in this report may not directly correspond to previous estimates (Marella, 1999) due to the assignment of variables weighed differently herein by the USGS or those by the SFWMD. For purposes of this analysis, agricultural withdrawals were limited to irrigation withdrawals; nonirrigation withdrawals (mostly for livestock purposes) were not estimated.

A modified Blaney-Criddle formulation with crop coefficients is used by three State of Florida water-management districts, including the SFWMD (Jacobs and Satti, 2001), to estimate consumptive crop water use. Consumptive water use includes both losses mostly associated with evapotranspiration but also the small amount of water consumed by incorporation in the plant tissue. For purposes of this report, the modified Blaney-Criddle equation (Blaney and others, 1952) was used to estimate evaporative losses (Jensen and others, 1990). The empirical equation relates rates of evapotranspiration with mean air temperature and mean percentage daytime hours. The original procedure was developed for estimating seasonal evapotranspiration, but later modified to estimate short-period use. Modifications include the use of climatic coefficients directly related to the mean air temperature for consecutive short growing seasons and coefficients that reflect the influence of the crop growth stage on consumptive use rate. Consumptive use rates may vary with temperature, length of day, and available moisture. Additionally, an allocation program was used to calculate a maximum monthly supplemental crop requirement and an average annual supplemental crop requirement using the modified Blaney-Criddle program.

Input data for the modified Blaney-Criddle program include mean rainfall, evapotranspiration, crop type, the number of plantings and plant growth duration (dependent on the crop type), an allocation coefficient, soil type, and the method of irrigation. Rainfall estimates were determined by averaging information from selected cities in Miami-Dade, Broward, and Palm Beach Counties. For example, Belle Glade, Jupiter, and West Palm Beach (fig. 15) were used to estimate precipitation in Palm Beach County. The period of record for mean rainfall in Palm Beach County was 35 years; Broward County (fig. 15, Pompano Beach and Fort Lauderdale) estimates are based on 41 years of record, whereas Miami-Dade County (fig. 15, Hialeah, Miami, and Homestead) includes 46.5 years of rainfall data. Consumptive water use was determined for crop types that include sugar cane, tomato, small vegetable, grass, citrus, and pasture. Tomatoes and small vegetable plants were assumed to be cultivated three times annually, whereas other crop types were considered to have been under cultivation for the entire year. An allocation coefficient was applied to different crop types, and a soil type factor of 0.8 was applied for all crops, except container ornamentals in which a factor of 1.5 was used. In this analysis, it is assumed that a sprinkler irrigation system is used for all crop types. Consumptive water use for specific crop types was estimated by county and used to determine evaporative losses for selected years.

\section{Findings on Agricultural Water Use}

Agricultural acreage in Miami-Dade, Broward, and Palm Beach Counties expanded dramatically during the latter half of the $20^{\text {th }}$ century. Areas under cultivation increased from more than 223,000 acres in 1953 to more than 535,000 acres in 1995 (fig. 22B). Completion of the West Palm Beach, Hillsboro, North New River, and Miami Canals by 1921 and construction of a levee along the southern 
rim of Lake Okeechobee provided opportunities for expansion of cultivated land near the lake, along major canals, and near some coastal areas. Areas under cultivation expanded nearly continuously in both Miami-Dade and Palm Beach Counties between 1953 and 1988 (fig. 22A). Southeastern Florida has experienced a decline in cultivated land since 1988 (fig. 22B); reduction in the agricultural economy of Broward County began in the 1950s largely due to encroachment by urban and residential areas. By the late 1980s, urban and residential development reduced Broward County agriculture to a minor factor in the county economy (Knetsch and Ethridge, 1992). In 1992, powerful winds from Hurricane Andrew swept across the southern Miami-Dade agricultural area, causing widespread damage and a financial loss to the agriculture industry that exceeded \$1 billion (Hebert and others, 1992; 1993) and contributed further to the regional decline in cultivated lands.

Estimated agricultural water use in the tri-county area increased from about 355 to $979 \mathrm{Mgal} / \mathrm{d}$ between 1953 and 1988, respectively, but decreased to about 632 $\mathrm{Mgal} / \mathrm{d}$ in 1995 (tables 2-5). The greatest increase in consumptive water use occurred in Palm Beach County, paralleling construction of the Everglades Agricultural Area during the latter half of the 1950s and an increase in sugar production in the United States during the 1960s.

\section{Mining}

Limestone and sand and gravel have been mined in southeastern Florida for construction and road material since the early 1920s (Gunter, 1927). Limestone extraction has played an important role in the westward expansion of urban areas, representing an inexpensive source of building material. The Venetian Pool, listed on the National Register for Historic Places and located in residential Coral Gables (fig. 15) was built in 1924. The public pool is the site of a former quarry used for construction materials during the early development of Coral Gables. By 1953, five companies extracted about 5.9 million tons of limestone in Broward, Miami-Dade, and Palm Beach Counties (Calver, 1957), increasing to 21.3 million tons by 1971.

As early as 1974, the U.S. Bureau of Mines recognized that limited land availability and mineral resource statutory restrictions place mining activities in conflict with urban development. Urban sprawl merely increased demand for crushed rock and construction aggregate at the same time as residential developers for the same land resource (Edgerton, 1974). The $89-\mathrm{mi}^{2}$ Lake Belt area in Miami-Dade County has become an area of intense resource competition (figs. 23A and 23B). Located on the eastern margin of the Everglades Shark River Slough historic flowway, the underlying limestone bedrock is characterized by high transmissivity and location of the largest well field in Florida - the Northwest Well Field (fig. 20). The same area represents the largest source of high-quality construction aggregate used for cement, building, and road material in Florida (Dade County Lake Belt Plan
Table 2. Estimated agricultural water use in Miami-Dade, Broward, and Palm Beach Counties in 1953

[Dashes indicates no data]

\begin{tabular}{lccccc}
\hline & \multicolumn{5}{c}{$\begin{array}{c}\text { Irrigation } \\
\text { requirement } \\
\text { (million }\end{array}$} \\
\hline $\begin{array}{c}\text { Estimated } \\
\text { land use } \\
\text { (acres) }\end{array}$ & $\begin{array}{c}\text { Adjusted } \\
\text { land use } \\
\text { (acres) }\end{array}$ & $\begin{array}{c}\text { gallons } \\
\text { per acre) }\end{array}$ & $\begin{array}{c}\text { Allocation } \\
\text { coefficient }\end{array}$ & $\begin{array}{c}\text { Estimated } \\
\text { total water use } \\
\text { (million gallons } \\
\text { per day) }\end{array}$ \\
\hline $\begin{array}{l}\text { Improved pasture } \\
\text { Vegetable crops } \\
\text { (row and field) }\end{array}$ & 8,192 & - & - & - & - \\
$\begin{array}{l}\text { Tree Crops } \\
\text { (citrus and fruit) }\end{array}$ & 75,135 & 41,324 & 13.69 & 1.30 & 54.71 \\
$\begin{array}{l}\text { Sugar cane } \\
\text { County total }\end{array}$ & 12,416 & 6,829 & 20.91 & 1.30 & 13.81 \\
\hline
\end{tabular}

\begin{tabular}{|c|c|c|c|c|c|}
\hline \multicolumn{6}{|c|}{ Broward County } \\
\hline Improved pasture & - & - & - & - & - \\
\hline $\begin{array}{l}\text { Vegetable crops } \\
\text { (row and field) }\end{array}$ & 55,886 & 50,297 & 16.04 & 1.30 & 78.03 \\
\hline $\begin{array}{l}\text { Tree crops } \\
\text { (citrus and fruit) }\end{array}$ & 2,048 & 1,843 & 22.94 & 1.30 & 4.09 \\
\hline Sugar cane & - & - & - & - & - \\
\hline County total & 57,934 & 52,141 & & & 82.11 \\
\hline \multicolumn{6}{|c|}{ Palm Beach County } \\
\hline Improved pasture & 16,640 & - & - & - & - \\
\hline $\begin{array}{l}\text { Vegetable crops } \\
\text { (row and field) }\end{array}$ & 62,512 & 56,261 & 14.07 & 1.30 & 76.56 \\
\hline $\begin{array}{l}\text { Tree crops } \\
\text { (citrus and fruit) }\end{array}$ & 128 & 115 & 21.15 & 1.30 & .24 \\
\hline Sugar cane & 143,950 & 129,555 & 20.59 & 1.40 & 277.83 \\
\hline County total & 223,230 & 185,931 & & & 354.62 \\
\hline
\end{tabular}


Table 3. Estimated agricultural water use in Miami-Dade, Broward, and Palm Beach Counties in 1977

[Dashes indicate no data]

\begin{tabular}{|c|c|c|c|c|c|}
\hline Category & $\begin{array}{c}\text { Estimated } \\
\text { land use } \\
\text { (acres) }\end{array}$ & $\begin{array}{l}\text { Adjusted } \\
\text { land use } \\
\text { (acres) }\end{array}$ & $\begin{array}{l}\text { Irrigation } \\
\text { requirement } \\
\text { (million } \\
\text { gallons } \\
\text { per acre) }\end{array}$ & $\begin{array}{l}\text { Allocation } \\
\text { coefficient }\end{array}$ & $\begin{array}{c}\text { Estimated } \\
\text { total water use } \\
\text { (million gallons } \\
\text { per day) }\end{array}$ \\
\hline \multicolumn{6}{|c|}{ Miami-Dade County } \\
\hline $\begin{array}{l}\text { Cropland and } \\
\text { pasture }\end{array}$ & 39,620 & 39,620 & 13.69 & 1.30 & 52.46 \\
\hline $\begin{array}{l}\text { Orchards, groves, } \\
\text { and nurseries }\end{array}$ & 13,098 & 13,098 & 20.91 & 1.30 & 26.49 \\
\hline $\begin{array}{l}\text { Other agricultural } \\
\text { land }\end{array}$ & 37 & 37 & 26.66 & 1.30 & .09 \\
\hline County Total & 52,754 & 52,754 & & 1.40 & 79.04 \\
\hline \multicolumn{6}{|c|}{ Broward County } \\
\hline $\begin{array}{l}\text { Cropland and } \\
\text { pasture }\end{array}$ & 60,340 & 45,255 & 16.04 & 1.30 & 70.20 \\
\hline $\begin{array}{l}\text { Orchards, groves, } \\
\text { and nurseries }\end{array}$ & 6,219 & 4,664 & 22.94 & 1.30 & 10.35 \\
\hline $\begin{array}{l}\text { Other agricultural } \\
\text { land }\end{array}$ & 117 & 88 & 22.15 & 1.30 & .19 \\
\hline County total & 66,677 & 50,007 & & & 80.74 \\
\hline \multicolumn{6}{|c|}{ Palm Beach County } \\
\hline $\begin{array}{l}\text { Cropland and } \\
\text { pasture }\end{array}$ & 577,615 & 288,807 & 17.33 & 1.30 & 484.05 \\
\hline $\begin{array}{l}\text { Orchards, groves, } \\
\text { and nurseries }\end{array}$ & 20,744 & 10,372 & 21.15 & 1.30 & 21.22 \\
\hline $\begin{array}{l}\text { Other agricultural } \\
\text { land }\end{array}$ & 455 & 228 & 26.74 & 1.30 & .59 \\
\hline County total & 598,814 & 299,407 & & & 505.86 \\
\hline
\end{tabular}

Table 4. Estimated agricultural water use in Miami-Dade, Broward, and Palm Beach Counties in 1988

[Dashes indicate no data]

\begin{tabular}{|c|c|c|c|c|c|}
\hline Category & $\begin{array}{c}\text { Estimated } \\
\text { land use } \\
\text { (acres) }\end{array}$ & $\begin{array}{c}\text { Adjusted } \\
\text { land use } \\
\text { (acres) }\end{array}$ & $\begin{array}{l}\text { Irrigation } \\
\text { requirement } \\
\text { (million } \\
\text { gallons } \\
\text { per acre) } \\
\end{array}$ & $\begin{array}{l}\text { Allocation } \\
\text { coefficient }\end{array}$ & $\begin{array}{c}\text { Estimated } \\
\text { total water use } \\
\text { (million gallons } \\
\text { per day) }\end{array}$ \\
\hline \multicolumn{6}{|c|}{ Miami-Dade County } \\
\hline Improved pasture & 6,934 & - & - & - & - \\
\hline Sugar cane & - & - & - & - & - \\
\hline Citrus groves & 8,238 & 6,305 & 20.51 & 1.30 & 12.51 \\
\hline Fruit orchards & 12,692 & 14,630 & 20.51 & 1.30 & 29.02 \\
\hline Sod farms & - & - & 27 & 1 & .00 \\
\hline Container ornamentals & 3,126 & 6,403 & 21.31 & 1.30 & 13.20 \\
\hline Golf courses & 5,229 & 3,888 & 26.66 & 1.30 & 10.02 \\
\hline Truck crops (row and field) & 59,935 & 51,808 & 13.69 & 1.30 & 68.59 \\
\hline County total & 96,154 & 83,034 & & & 133.34 \\
\hline \multicolumn{6}{|c|}{ Broward County } \\
\hline Improved pasture & 26,045 & - & - & - & - \\
\hline Sugar cane & - & - & - & - & - \\
\hline Citrus groves & 3,060 & 589 & 22.15 & 1.30 & 1.26 \\
\hline Fruit orchards & - & - & - & - & - \\
\hline Sod farms & - & - & - & - & - \\
\hline Container ornamentals & 766 & 2,453 & 23.73 & 1.30 & 5.63 \\
\hline Golf courses & 8,378 & 6,662 & 29.09 & 1.30 & 18.74 \\
\hline $\begin{array}{l}\text { Truck crops } \\
\text { (row and field) }\end{array}$ & 3,325 & 5,793 & 16.04 & 1.30 & 8.99 \\
\hline County total & 41,573 & 15,497 & & & 34.62 \\
\hline \multicolumn{6}{|c|}{ Palm Beach County } \\
\hline Improved pasture & 23,003 & 445 & 13.34 & 1.30 & .57 \\
\hline Sugar cane & 478,242 & 323,433 & 20.59 & 1.40 & 693.60 \\
\hline Citrus groves & 23,735 & 15,545 & 20.51 & 1.30 & 30.83 \\
\hline Fruit orchards & 37 & - & - & - & - \\
\hline Sod farms & 13,137 & 21,429 & 26.74 & 1.40 & 59.68 \\
\hline Container ornamentals & 5,480 & 1,349 & 21.80 & 1.30 & 2.84 \\
\hline Golf courses & 14,304 & 17,457 & 26.74 & 1.30 & 45.15 \\
\hline Truck crops (row and field) & 33,476 & 107,205 & 14.07 & 1.30 & 145.88 \\
\hline County total & 591,414 & 486,863 & & & 978.56 \\
\hline
\end{tabular}


Table 5. Estimated agricultural water use in Miami-Dade, Broward, and Palm Beach Counties in 1995

[Dashes indicate no data]

\begin{tabular}{|c|c|c|c|c|c|}
\hline Category & $\begin{array}{c}\text { Estimated } \\
\text { land use } \\
\text { (acres) }\end{array}$ & $\begin{array}{c}\text { Adjusted } \\
\text { land use } \\
\text { (acres) }\end{array}$ & $\begin{array}{l}\text { Irrigation } \\
\text { requirement } \\
\text { (million } \\
\text { gallons } \\
\text { per acre) }\end{array}$ & $\begin{array}{l}\text { Allocation } \\
\text { coefficient }\end{array}$ & $\begin{array}{c}\text { Estimated } \\
\text { total water use } \\
\text { (million gallons } \\
\text { per day) }\end{array}$ \\
\hline \multicolumn{6}{|c|}{ Miami-Dade County } \\
\hline Improved pasture & 4,462 & - & - & - & - \\
\hline Sugar cane & - & - & - & - & - \\
\hline Citrus groves & 3,884 & 1,668 & 20.51 & 1.30 & 3.31 \\
\hline Fruit orchards & 59 & 10,400 & 20.51 & 1.30 & 20.63 \\
\hline Sod farms & 60 & - & - & - & - \\
\hline $\begin{array}{l}\text { Container ornamen- } \\
\text { tals }\end{array}$ & 7,066 & 8,403 & 21.31 & 1.30 & 17.32 \\
\hline Golf courses & 5,237 & 4,223 & 26.66 & 1.30 & 10.89 \\
\hline Row crops & 43,760 & 42,760 & 13.14 & 1.30 & 54.34 \\
\hline Field crops & 17,874 & - & - & - & - \\
\hline Tree nurseries & 79 & - & - & - & - \\
\hline County total & 82,480 & 67,454 & & & 106.48 \\
\hline \multicolumn{6}{|c|}{ Broward County } \\
\hline Improved pasture & 13,961 & - & - & - & - \\
\hline Sugar cane & - & - & - & - & - \\
\hline Citrus groves & - & - & - & - & - \\
\hline Fruit orchards & - & - & - & - & - \\
\hline Sod farms & - & - & - & - & - \\
\hline $\begin{array}{l}\text { Container ornamen- } \\
\text { tals }\end{array}$ & 827 & 2,668 & 23.73 & 1.30 & 6.12 \\
\hline Golf courses & 8,105 & 7,360 & 29.09 & 1.30 & 20.71 \\
\hline Row crops & 2,123 & 350 & 18.52 & 1.30 & 0.63 \\
\hline Field crops & 51 & - & - & - & - \\
\hline Tree nurseries & 898 & - & - & - & - \\
\hline County total & 25,965 & 10,378 & & & 27.46 \\
\hline
\end{tabular}

\begin{tabular}{|c|c|c|c|c|c|}
\hline Category & $\begin{array}{c}\text { Estimated } \\
\text { land use } \\
\text { (acres) }\end{array}$ & $\begin{array}{l}\text { Adjusted } \\
\text { land use } \\
\text { (acres) }\end{array}$ & $\begin{array}{l}\text { Irrigation } \\
\text { requirement } \\
\text { (million } \\
\text { gallons } \\
\text { per acre) }\end{array}$ & $\begin{array}{l}\text { Allocation } \\
\text { coefficient }\end{array}$ & $\begin{array}{c}\text { Estimated } \\
\text { total water use } \\
\text { (million gallons } \\
\text { per day) }\end{array}$ \\
\hline \multicolumn{6}{|c|}{ Palm Beach County } \\
\hline Improved pasture & 3,171 & - & - & - & - \\
\hline Sugar cane & 464,165 & 334,837 & 10.50 & 1.40 & 366.18 \\
\hline Citrus groves & 20,042 & 12,885 & 20.51 & 1.30 & 25.56 \\
\hline Fruit orchards & 165 & - & - & - & - \\
\hline Sod farms & 399 & 20,000 & 26.74 & 1.40 & 55.70 \\
\hline $\begin{array}{l}\text { Container ornamen- } \\
\text { tals }\end{array}$ & 4,327 & 4,807 & 21.80 & 1.30 & 10.13 \\
\hline Golf courses & 17,862 & 16,210 & 26.74 & 1.30 & 41.92 \\
\hline Row crops & 21,961 & 63,295 & 18.97 & 1.30 & 116.12 \\
\hline Field crops & 1,506 & 18,364 & 9.17 & 1.30 & 16.29 \\
\hline Tree nurseries & 1,158 & - & - & - & - \\
\hline County total & 534,756 & 470,398 & & & 631.90 \\
\hline
\end{tabular}



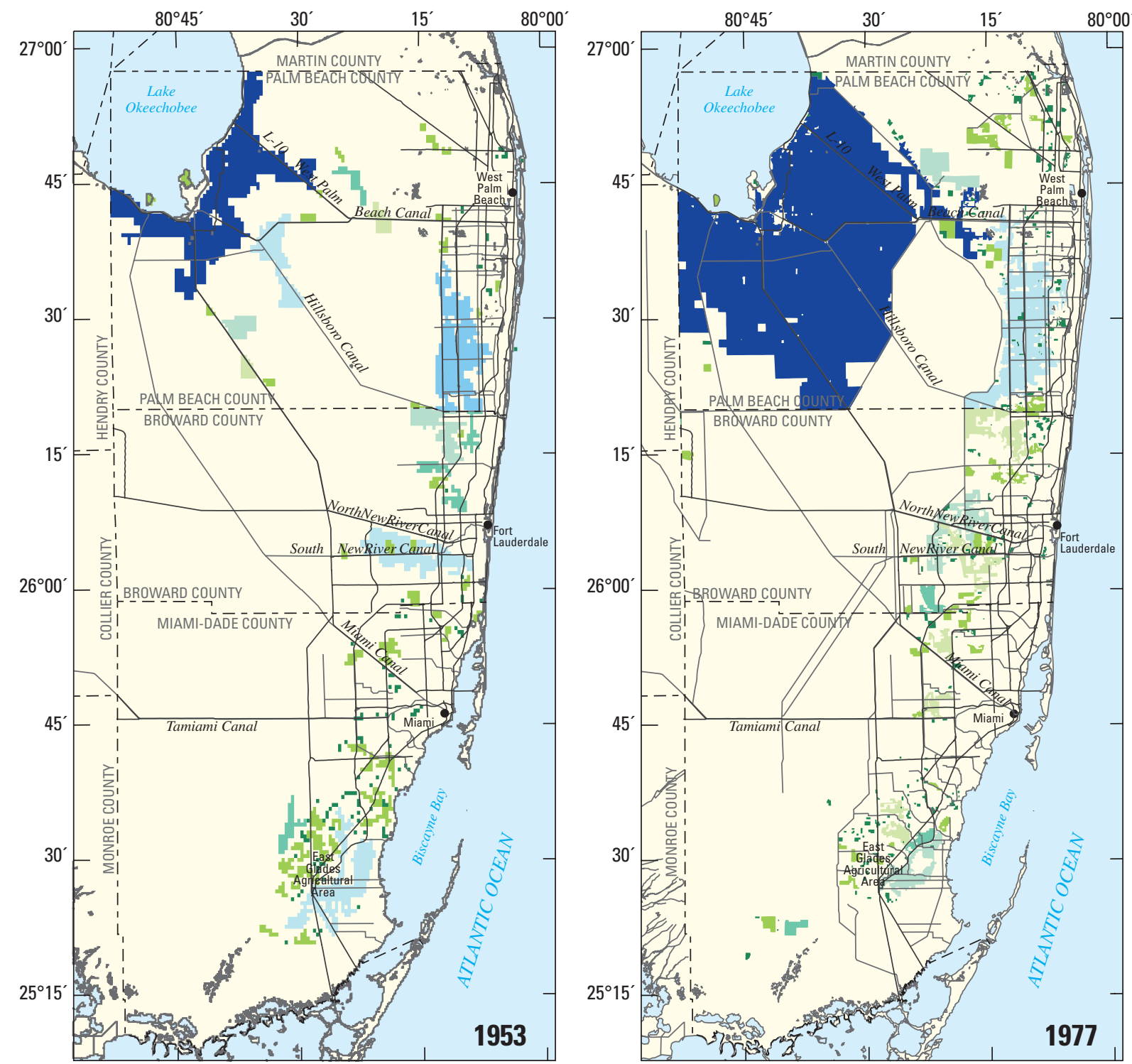

\section{EXPLANATION}

AGRICULTURAL WATER USE, IN MILLION GALLONS PER DAY

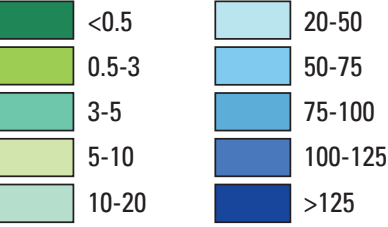

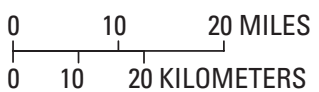

Figure 22A. Estimated agricultural water use in Miami-Dade, Broward, and Palm Beach Counties during 1953 and 1977. 

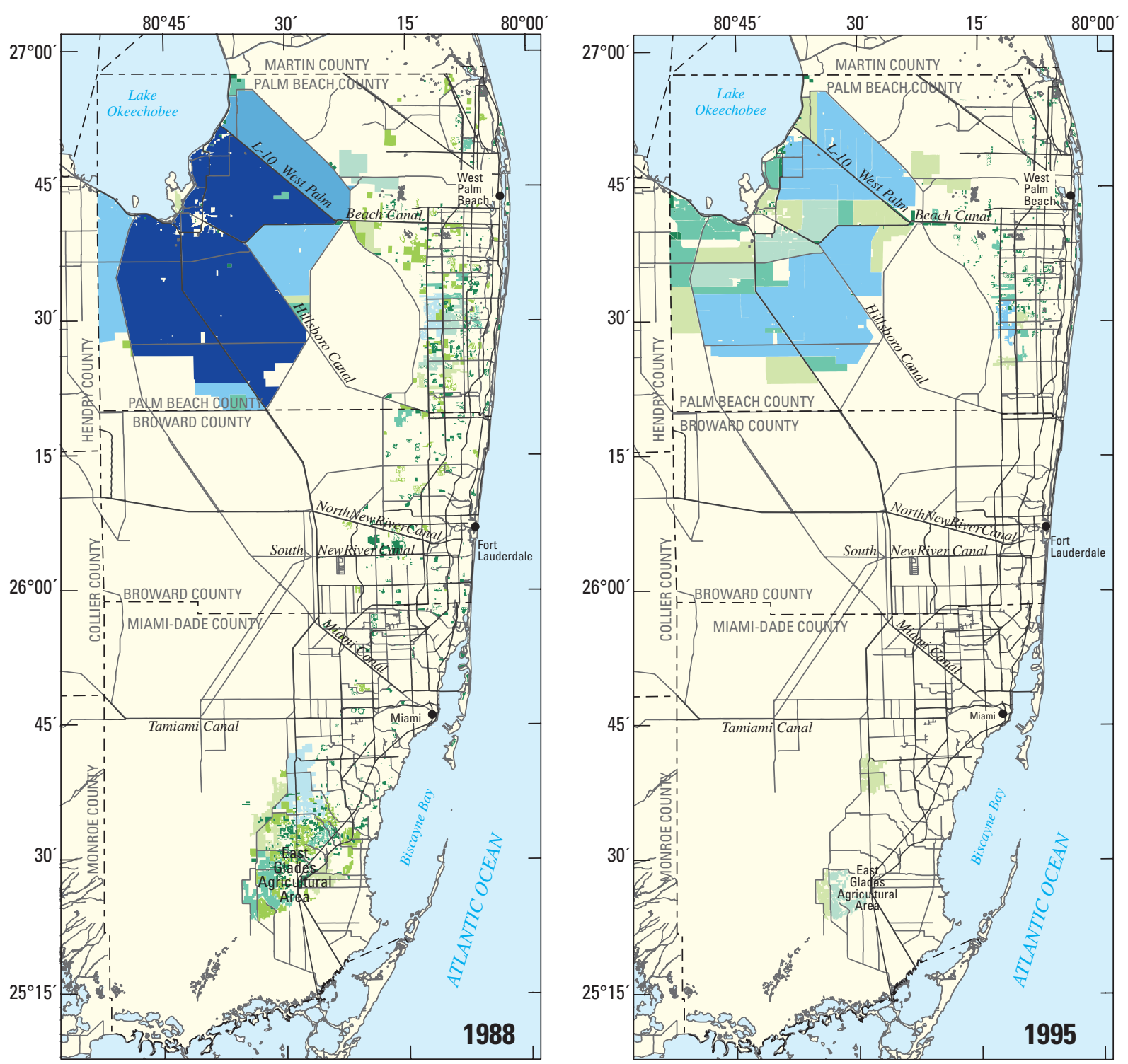

\section{EXPLANATION}

AGRICULTURAL WATER USE, IN

MILLION GALLONS PER DAY
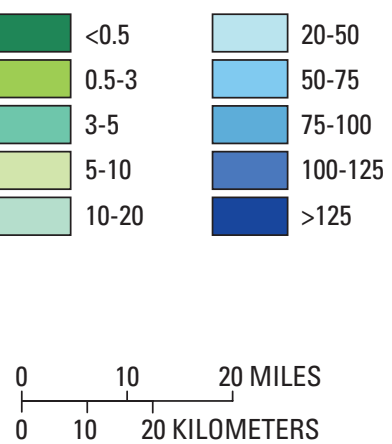

\section{$\begin{array}{lll}0 & 10 & 20 \text { KILOMETERS }\end{array}$}

Figure 22B. Estimated agricultural water use in Miami-Dade, Broward, and Palm Beach Counties during 1988 and 1995. 


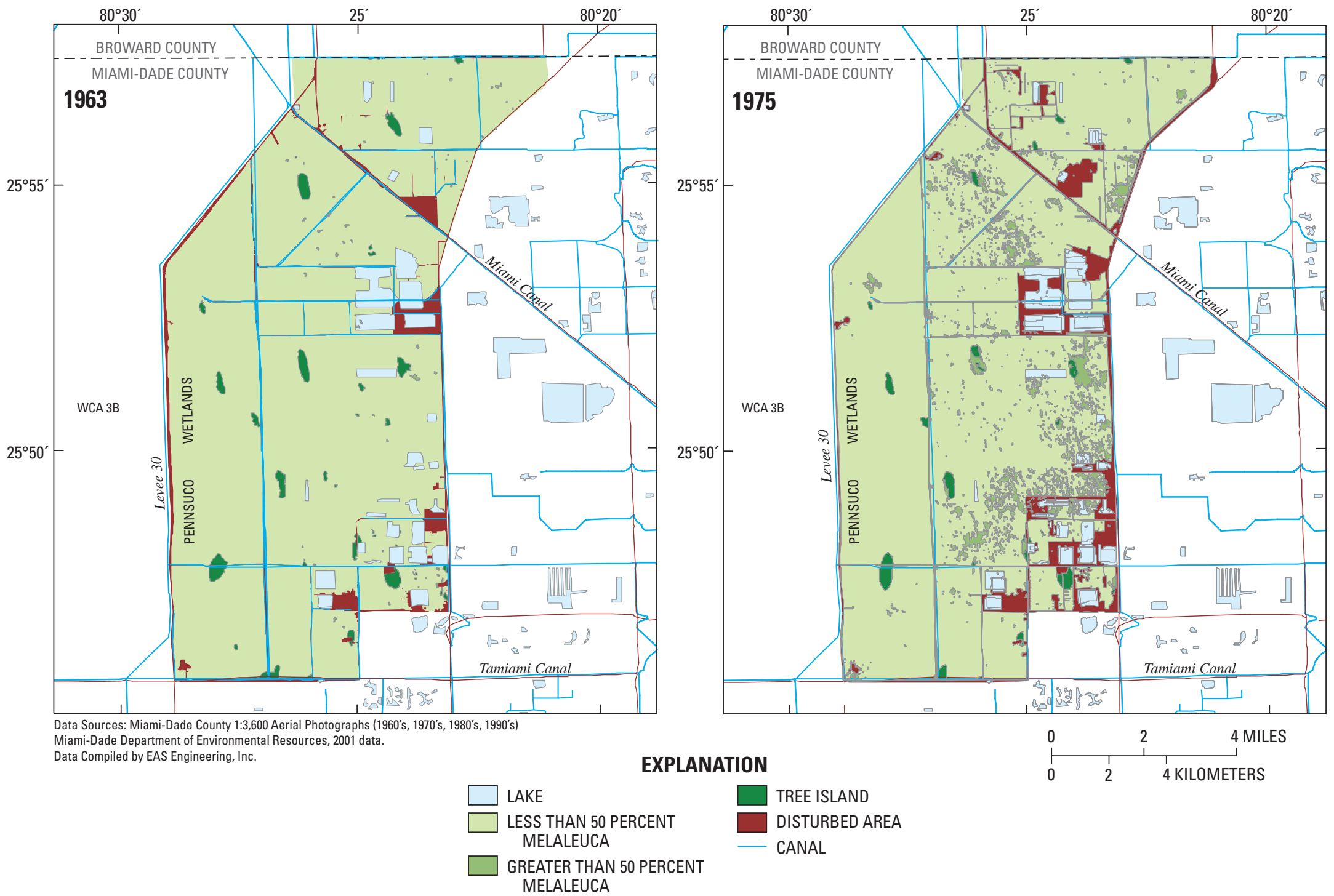

Figure 23A. Extent of limestone borrow pit mines in the Lake Belt area in 1963 and 1975. Courtesy of E.A. Swayon, EAS Enginnering, Inc. (written commun., 2003). 


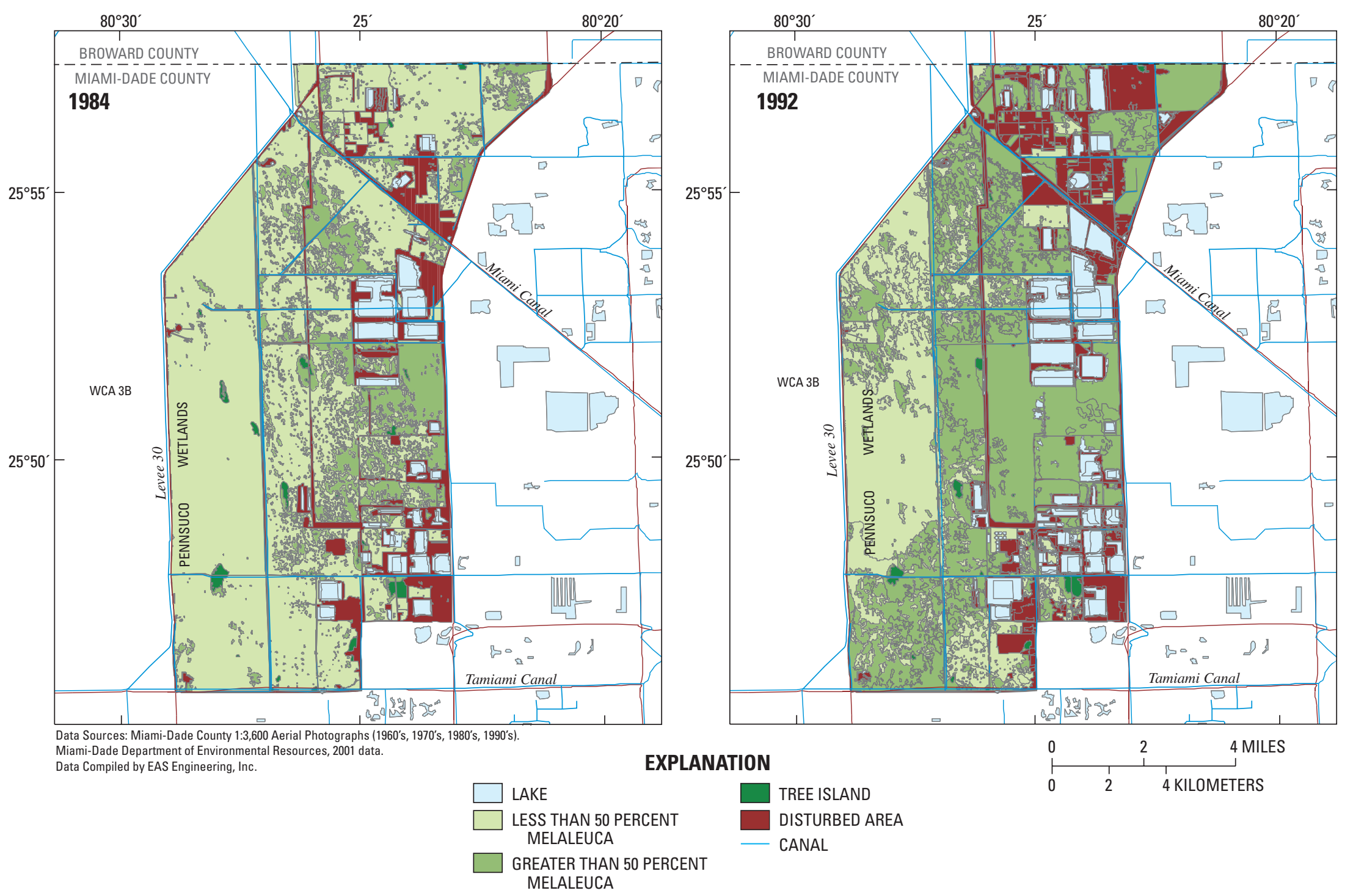

Figure 23B. Extent of limestone borrow pit mines in the lake Belt area in 1984 and 1992. Courtesy of E.A. Swayon, EAS Enginnering, Inc. (written commun., 2003). 
Implementation Committee, 1997). By the close of the $20^{\text {th }}$ century, 35 to 40 million tons of limestone were extracted in northwestern Miami-Dade County on an annual basis (Northwest Dade County Freshwater Lake Plan Implementation Committee, 1997).

Mining operations in northwestern Miami-Dade County have been active since the 1950s but their size and extent were comparatively limited until the 1980s (figs. 23A, 23B, and 24). Florida's 1984 Henderson Wetlands Act recognized that there was substantial economic value in the limestone mineral reserves in MiamiDade County; although this legislative act was designed to mitigate wetland destruction, it exempted mining in wetland areas bordering Everglades National Park heavily infested with exotic melaleuca trees. Borrow-pit mining is transforming wetland areas into deep quarry lakes, 30 to $80 \mathrm{ft}$ in depth. Proposed expansion of mining operations and the conversion of abandoned quarries to in-ground reservoirs as part of the Everglades restoration have created unresolved public health concerns regarding increased well-field vulnerability to surface-water pathogen contamination, and environmental concerns associated with the potential increase in seepage from water-conservation areas and the nearby Pennsuco wetlands area (figs. 23A and 23B).

During the 1980s and 1990s, limestone extraction methods increased the available urban residential waterfront property through excavation of artificial lakes in western and central Palm Beach and Broward Counties (fig. 25). Residential artificial lakes are largely multipurpose in nature, having served to: (1) provide construction fill for roads, (2) elevate low-lying lands for development in former marginal wetland areas, (3) reduce urban flooding, and (4) help increase land values due to their aesthetic appearance (Frederick and others, 1997). In Palm Beach County, water is pumped from the Hillsboro Canal into Lake Worth Drainage District canals near Boca Raton, in part, to maintain water levels within local community artificial lakes.

\section{Use of Alternative Aquifers for Supply and Wastewater Management}

As previously mentioned, increased withdrawals and substantial land-use changes have adversely affected the balance between freshwater and saltwater in the surficial aquifer system in southeastern Florida. Mitigation of an aquifer contaminated with saltwater is costly, difficult, and achieved only after a lengthy period of time. Some well fields have been consolidated, some coastal well fields have been abandoned, and others have been constructed farther inland accompanied by the adoption and enforcement of wellhead protection plans. Construction of additional municipal well fields in the western part of the urban corridor, however, is ultimately limited by competing supply needs of agriculture, the Everglades ecosystem and
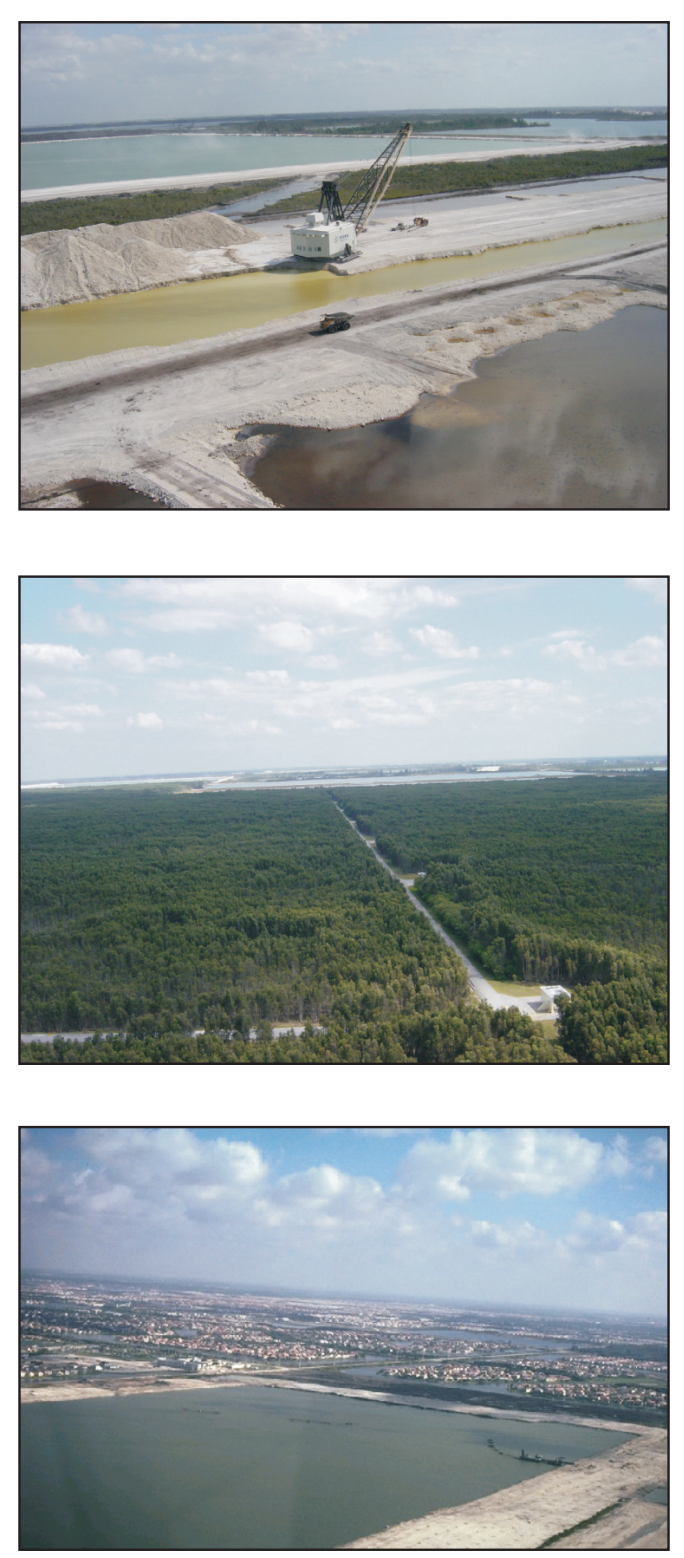

Figure 24. Lake Belt limestone borrow-pit mine in Miami-Dade County. Photographs courtesy of the South Florida Water Management District archives. 

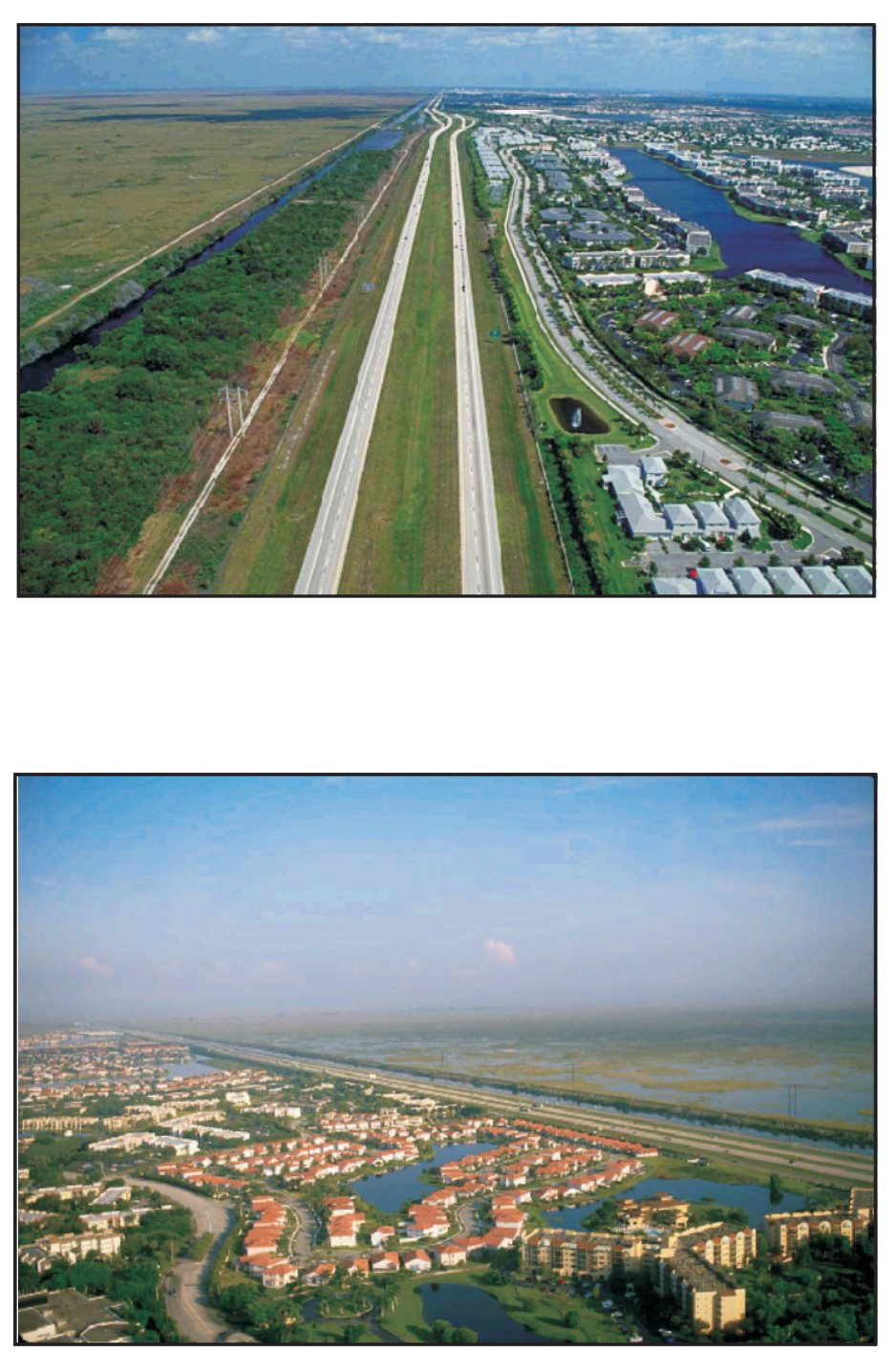

Figure 25. Artificial lakes along the Sawgrass Expressway in reclaimed wetland areas adjoining water-conservation areas in Broward County. These artificial lakes have served as a source of artificial fill for residential construction and to capture stormwater runoff. Photographs courtesy of the South Florida Water Management District archives. water-conservation areas, and expanding mining interests. Alternate sources of water and effective means of storage have been of critical interest to resource managers.

Experimental freshwater aquifer storage and recovery (ASR) systems were first constructed in Miami-Dade and Palm Beach Counties during the 1970s; the Boynton Beach ASR facility represents the first operational system (1992). Most existing southern Florida ASR wells are completed in the Upper Floridan aquifer, the upper of two regional aquifers that form the extensive carbonate Floridan aquifer system that underlies the intermediate confining unit (fig. 6). By the end of the $20^{\text {th }}$ century, ASR was being evaluated to meet growing urban, agricultural, and ecosystem supply demands (Fies and others, 2002; Reese, 2002). Five new systems were under operational testing by 2000, and a network of 330 large-capacity ASR wells for restoration purposes was being evaluated as part of the Comprehensive Everglades Restoration Plan (CERP) (U.S. Corps of Engineers and South Florida Water Management District, 1999; National Research Council, 2001; 2002). Considerable scientific, engineering, and cost-related feasibility issues must be resolved, however, and it is uncertain whether an ASR infrastructure of unprecedented scale can meet ecosystem restoration, agricultural and urban needs. Pilot and regional studies have been initiated to characterize the regional hydrology and geologic framework, assess the potential impact on the regional ground-water flow system (fig. 26), characterize biogeochemical reactions, and examine ecosystem sensitivity to recovered water (Fies and others, 2002; U.S. Army Corps of Engineers and South Florida Water Management District, 2002; Ward and others, 2003).

Utilization of water withdrawn from the Upper Floridan aquifer for publicsupply purposes is limited by salinity that exceeds U.S. Environmental Protection Agency (1999) secondary drinking-water standards. Reverse-osmosis treatment of Upper Floridan aquifer water for municipal use represents a growing watersupply trend, particularly in Palm Beach County, which has been projected to have a public-supply demand of 338 million gallons by 2020 (Marella, 1992). Palm Beach reverse-osmosis production wells that obtain water from the Upper Floridan aquifer have been constructed in Highland Beach, Jupiter, and Tequesta (fig 15D). Reverse osmosis also is used in Broward County to treat Upper Floridan aquifer water for the city of Hollywood.

Historically, the cost of treating wastewater effluent in southeastern Florida was accompanied by concern that an expanded system of ocean outfalls would degrade coastal beach areas. Such concern in the 1970s contributed to public acceptance that deep well injection represented the preferred wastewater management alternative (Garcia-Benochea and others, 1973). First applied in Broward County in 1959 (Hickey and Vecchioli, 1986), the disposal of liquid wastewater into saline carbonate rocks by deep well injection has been used increasingly during the latter half of the $20^{\text {th }}$ century for municipal and industrial wastewater and for disposal of reverseosmosis concentrate. More than 20 Class I injection municipal and industrial 


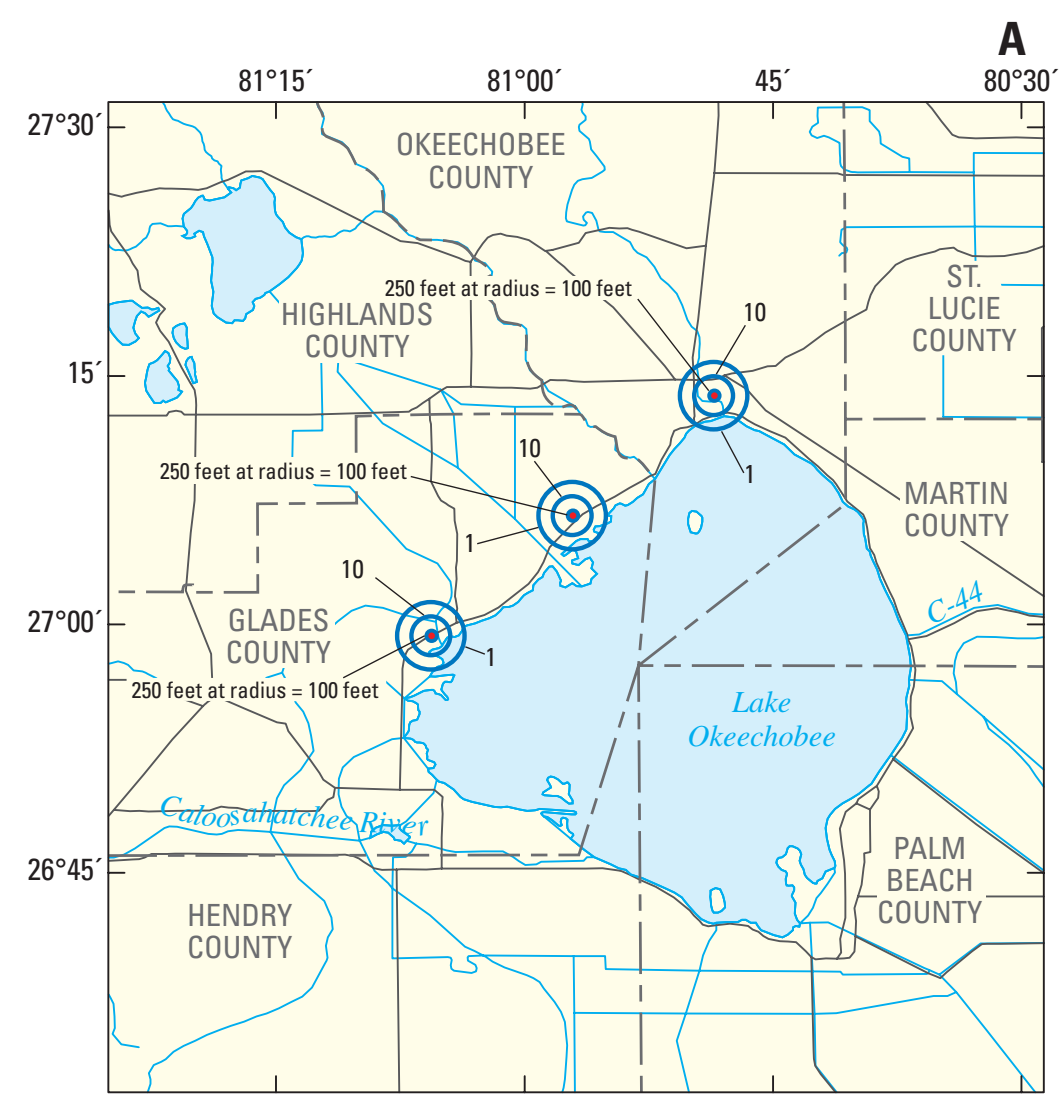

EXPLANATION

- 10 - LINE OF HYPOTHETICAL INCREASE IN WATER LEVEL-In feet

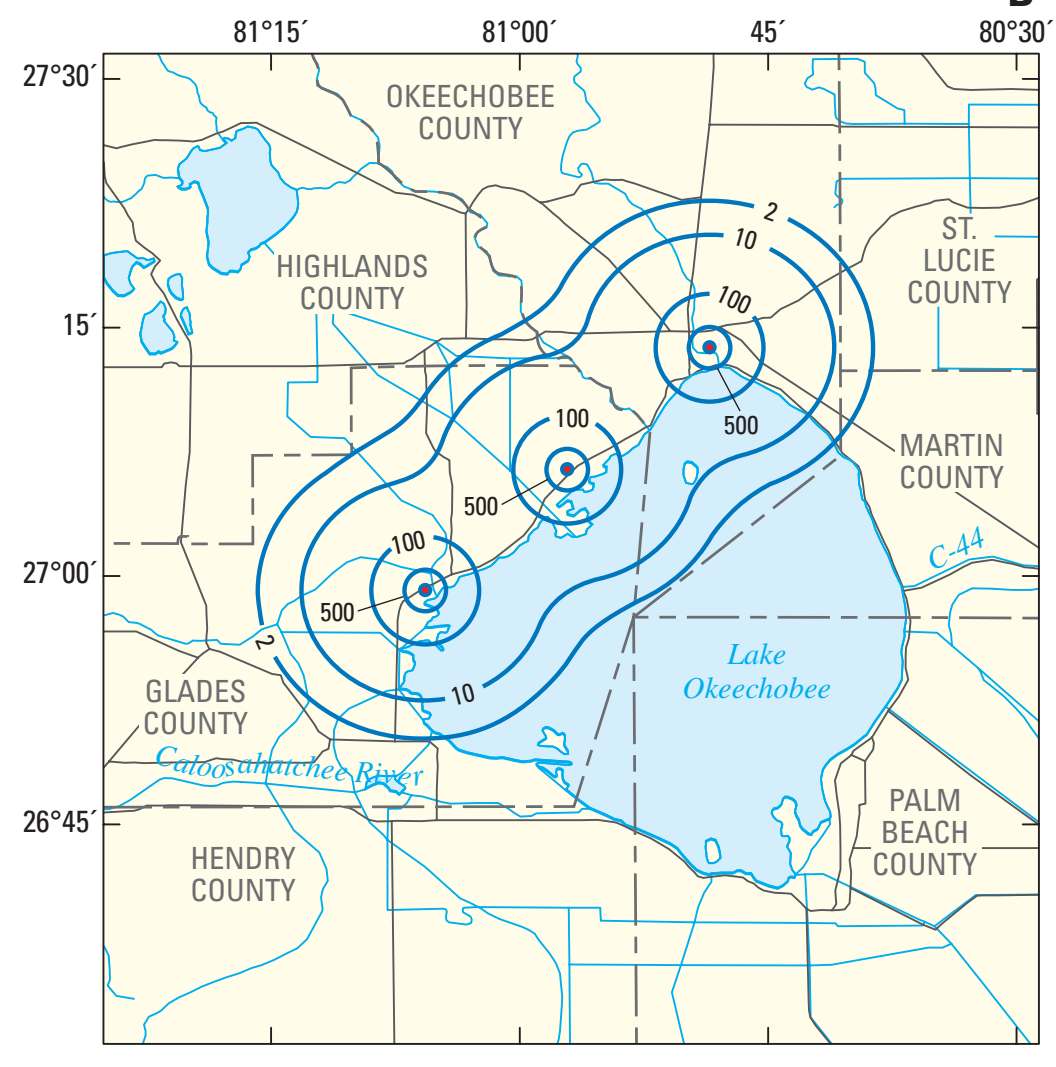

$$
\underbrace{0}_{0} \underbrace{10}_{20} \underbrace{10}_{20 \text { KILOMETERS }} \stackrel{20 \text { MILES }}{\perp}
$$

Figure 26. Hypothetical aquifer storage and recovery (ASR) pressure buildup in the Upper Floridan aquifer using the Hantush-Jacob (1955) analytical model, assuming $(A)$ relatively high transmissivity and confining bed leakance or $(B)$ relatively low transmissivity and confining bed leakance. This analytical model can be used to bracket uncertainty associated with large-scale head buildup using a known range of Upper Floridan aquifer hydraulic parameters. Although not mechanically possible, it was assumed that 1 billion gallons of water could be injected into three wells located about 12 miles apart for a time period of 180 days and one for a period of 2.5 years. Steady-state conditions were achieved in 180 days. The Hantush-Jacob analytical model greatly simplifies potential hydraulic responses within the Upper Floridan aquifer; however, the model can be used to assess the relative impact of likely range aquifer and confining unit hydraulic parameters including transmissivity $\left(T=100,000\right.$ square feet per day), time $(t=0.5$ and 2.5 years $)$, storage $(S=0.005)$, underlying confining unit leakance $\left(K^{\prime} / b^{\prime}=0.01\right.$ day $\left.{ }^{-1}\right)$, and discharge $\left(0=3.33 \times 10^{8}\right.$ gallons per day per well). This example illustrates sensitivity to water-level changes in terms of uncertainty is ASR storage zone hydraulic parameters. From L.C. Murray, U.S. Geological Survey (written commun., 2002) and Fies and others (2002). 
facilities were operating in Palm Beach, Broward, and Miami-Dade Counties by 2000, injecting treated wastewater into the highly permeable Boulder Zone of the Lower Floridan aquifer at depths of 2,000 to 3,000 ft below NGVD 1929. In recent years, however, deep well injection has received considerable scrutiny because of the uncertain efficacy of overlying confining units and the reported upward leakage of effluent that has been observed in some monitoring wells.
Okeechobee (fig. 26) helped to lower lake levels and created downstream drainage issues. Disston's reclamation efforts were ultimately hampered financially because of poor investment return on reclaimed land and the nationwide economic Panic of 1893. Pro-reclamation proponents, however, supporting drainage of the Everglades held strong convictions that drainage efforts would ultimately transform wetland muck into fertile farmland soil. The extension of the railroad to Miami in 1896 by industrialist Henry Flagler was combined with development of small cities and

"Our swamps are the greatest single menace that remains to public health. As a people we cannot feel that our full duty has been performed until we have made these swamp land centers of prosperity and comfort for ourselves and those who shall come after....

They are not unproductive; they can be made sources of great national wealth."

\author{
M.O. Leighton \\ Chief Hydrographer \\ U.S. Geological Survey, 1912
}

\section{Development of Water-Management System and Impact on the Hydrology of Southeastern Florida}

During the $19^{\text {th }}$ and throughout most of the $20^{\text {th }}$ century, the American freshwater wetland (swamps) and coastal estuary paradigm differed considerably from scientific and environmental perspectives expressed in the 1990s. Swamps were considered to be vast wastelands that could better serve the Nation if drained into productive agricultural lands. For many Americans, the Nation's wetlands represented a potential source of disease and pestilence. In speeches presented to the National Irrigation Congress (Chicago) and National Drainage Congress (New Orleans) in 1912, the Chief Hydrographer of the USGS, Marshall O. Leighton, declared the reclamation of America's swamps to be a "matter of National necessity." Furthermore, Leighton (1912) stated that wetlands were "the greatest single menace that now remains to public health," describing them as "a source of weakness in our National economy."

During the latter part of the 1800s and early 1900s, the ceding of Federal land to the State of Florida was accompanied by reclamation activities to develop a tropical-based agriculture. Drainage efforts by entrepreneur Hamilton Disston provided modest success within wetland areas of the Kissimmee River Basin in central Florida. Canals built by Disston linked the Caloosahatchee River south with Lake resorts along southeastern Florida coast that, in part, were designed to attract the Nation's most wealthy vacationers (George, 1996).

Reclamation continued south of the lake with completion of the West Palm Beach (1907), Hillsboro (1907), North New River (1913), and Miami (1913) Canals by the Everglades Drainage District (fig. 27A). Construction of a low levee that rimmed the southern side of Lake Okeechobee (1924) increased the amount of land available for agricultural development, especially along the major canals and tracts of land south of the lake (fig. 28). The canals served to increase the rate of flow from the Everglades, which reduced the extent of inundated land and lowered groundwater levels near drainage canals and along the western edge of the Atlantic Coastal Ridge (fig. 5). Early drainage construction efforts (figs. 29 and 30) proved only modestly successful as the principal canals generally failed to transport the imposed flood load (Parker and others, 1955). Additional improvements were made during the late 1920s to the Caloosahatchee River and C-44 Canal (fig. 26) to more effectively drain Lake Okeechobee.

The Tamiami Canal, a major component of the Everglades drainage system, extends westward from its terminus at the Miami Canal to the southwestern coast of Florida discharging near Naples (west of the study area). The Tamiami Canal, completed in 1928, was not designed for drainage purposes, but was used to provide fill to build a road (fig. 1, Tamiami Trail) along its length, linking Miami with Naples. The central and western reaches of the canal collect water as sheetflow and funnel 

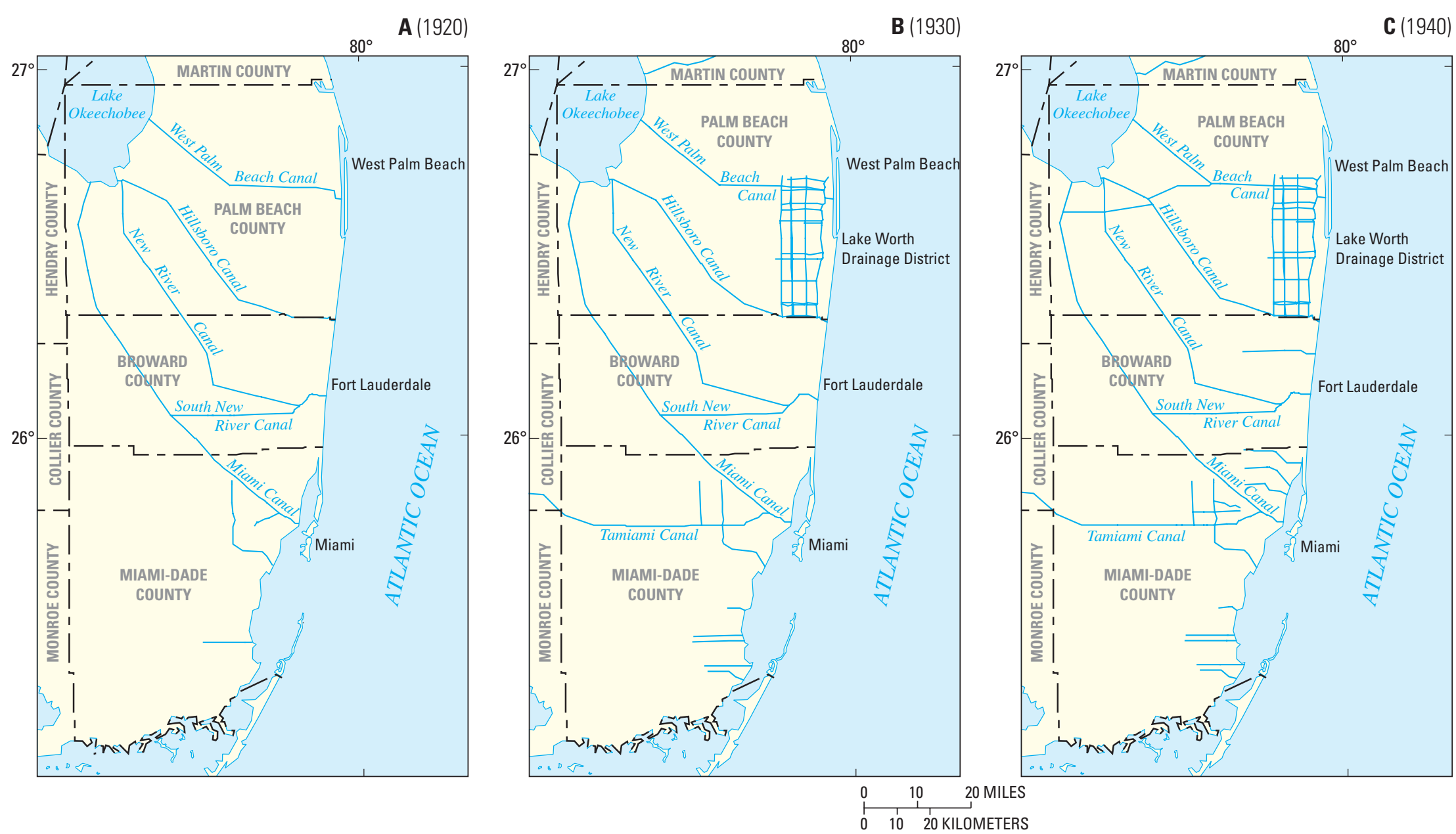

Figure 27. Surface-water conveyance features in Miami-Dade, Broward, and Palm Beach Counties in $(A)$ 1920, $(B)$ 1930, and $(C)$ 1940. Modified from data and files of the South Florida Water Management District, U.S. Army Corps of Engineers, and the U.S. Geological Survey. 


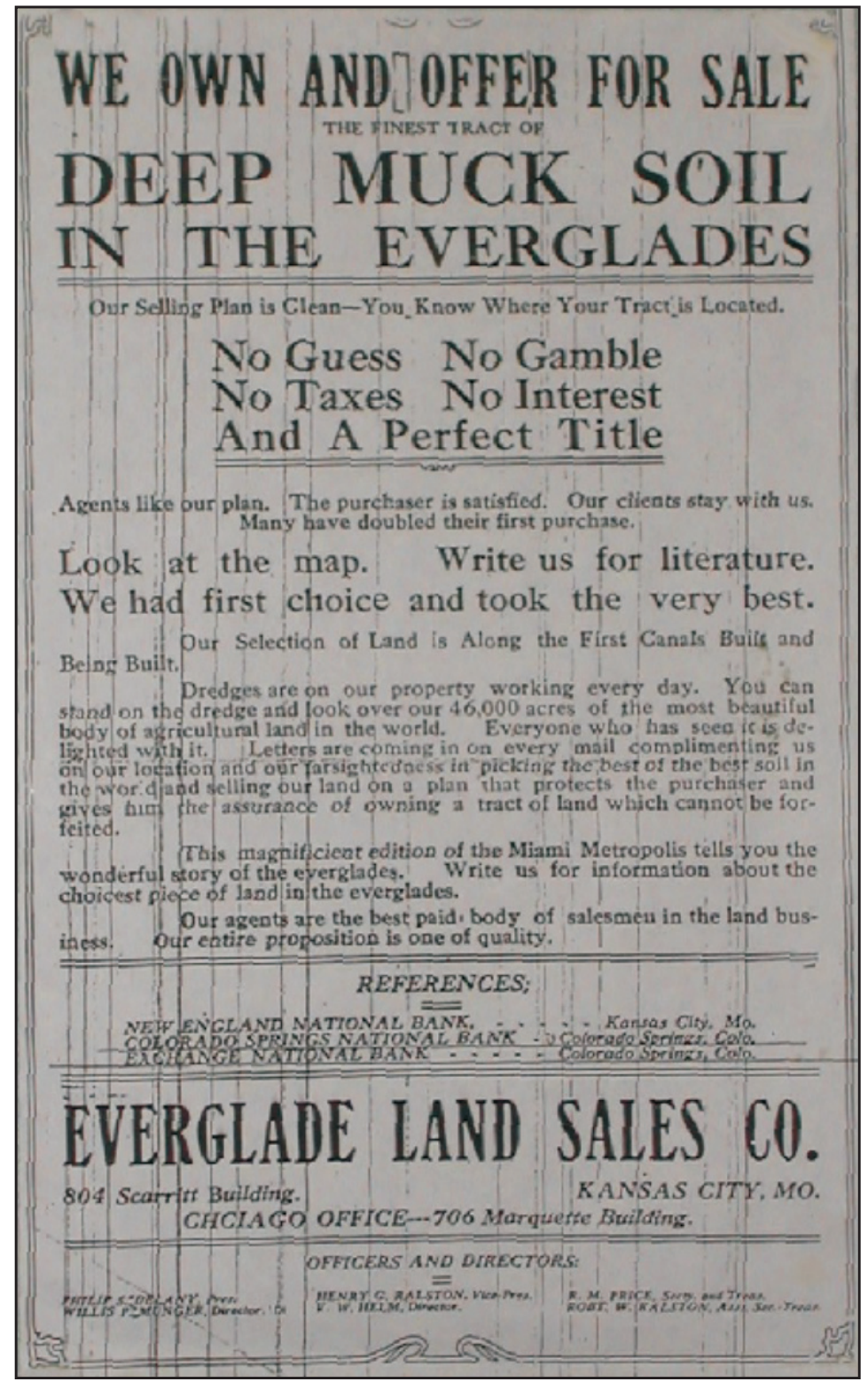

Figure 28. Poster (circa 1910) used to attract buyers of newly drained agricultural lands. courtesy of the Davie, Florida Historical Society.

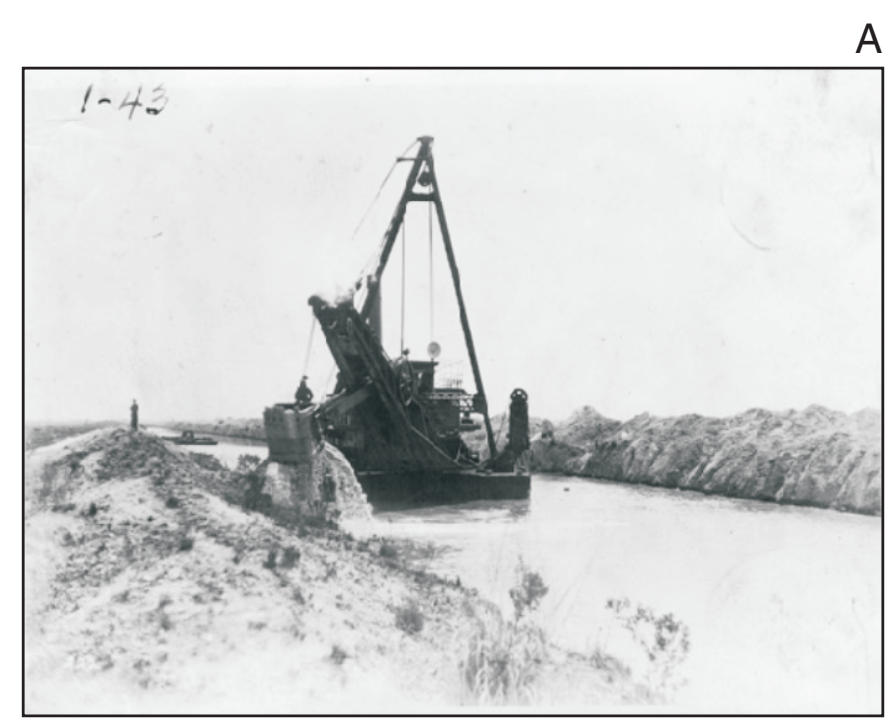

A

B

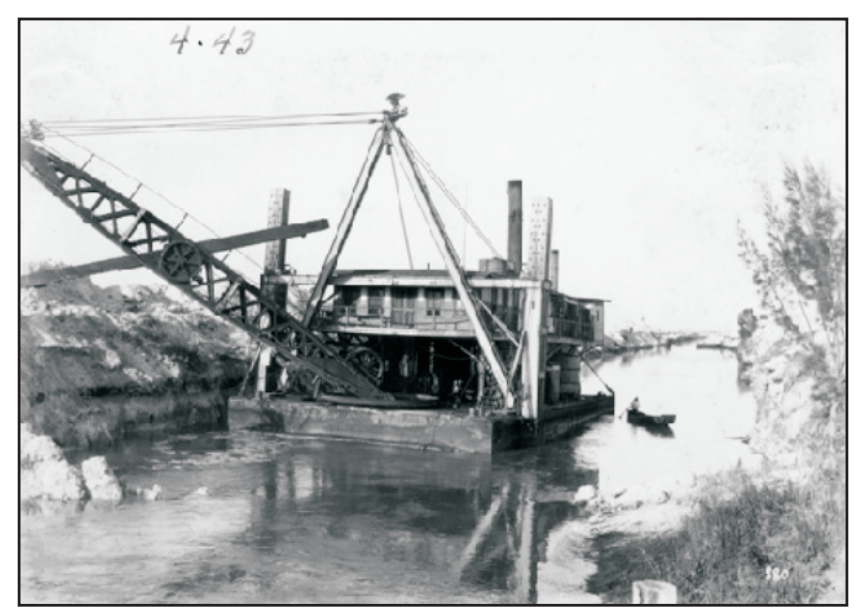

Figure 29. Dredging of the (A) Miami Canal at Hialeah in 1919 and $(B)$ the South New River Canal at Davie in 1920. Digitized photographs held by the Historical Museum of Southern Florida, Miami, Florida. From the C.C. Matlack Collection. 

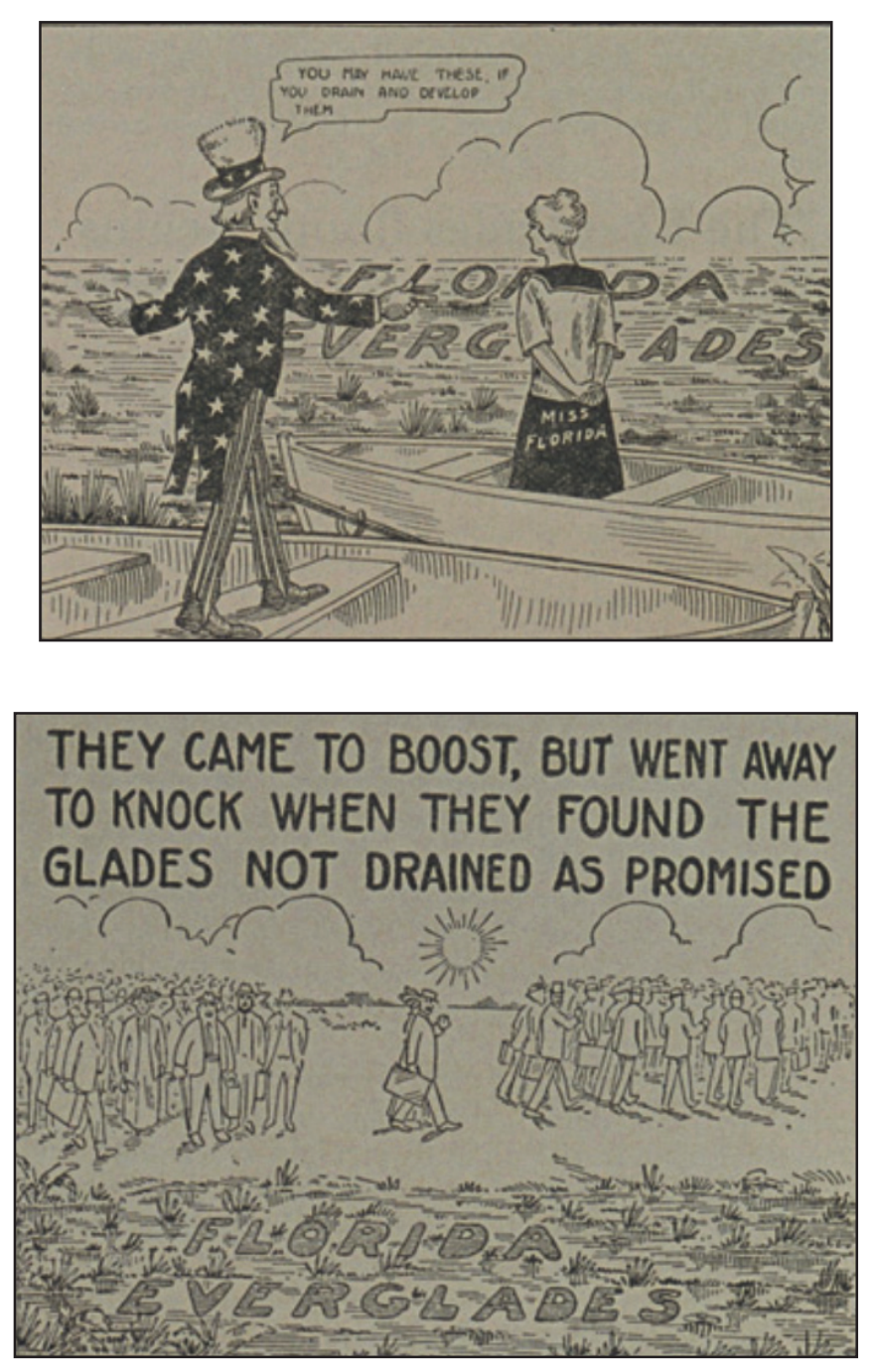

Figure 30. Political cartoons published for the "Back to Broward League" (Carson, 1916). The Back to Broward League was formed by a group of Fort Lauderdale residents actively promoting efforts to drain the Everglades, and had criticized the State government for its failure to adequately finance ongoing drainage efforts. Courtesy of Florida International University digital library and Historical Museum of Southern Florida. it through culverts southward into Everglades National Park and the Big Cypress Basin (Swamp). Landfilling construction activities associated with development of Flagler's Florida Keys railroad helped to alter Florida Bay circulation patterns, and water-management practices reduced surface flow to the bay and ultimately modified its salinity and ecology (McIvor and others, 1994; Halley and Roulier, 1999; Halley, 2002). The impact of the Tamiami Trail on surface-water flows to Florida Bay was less certain (Light and Dineen, 1994, p. 55).

The Lake Worth Drainage District (LWDD) was developed during the late 1920s (fig. 27B). This major early water-management feature was constructed to reclaim and improve land within its boundaries, and to offer water control and water supply for urban settlement and agriculture. The LWDD occupies about $200 \mathrm{mi}^{2}$ in Palm Beach County and extends from West Palm Beach to the Broward County line. Management of water resources in the LWDD is achieved by use of 50 east-west lateral canals and 4 north-south equalizing canals. Whereas drainage of the Everglades wetland areas affected coastal ground-water levels, the LWDD is designed to maintain higher coastal ground-water levels, withdrawing water from the Hillsboro and West Palm Beach Canals.

By 1930, the network of mostly uncontrolled canals (fig. 27B) drained large quantities of freshwater from the Everglades into the Atlantic Ocean, lowering water levels in the Everglades as much as $6 \mathrm{ft}$ (Kohout, 1964). In response to the hurricanerelated flooding and mortality in agricultural lands south of Lake Okeechobee in 1926 and 1928, a larger elevated dike (Hoover Dike) was completed on the southern and northern parts of Lake Okeechobee in 1938 (figs. 27C and 31).

The drought of 1943-46 and hurricanes of 1947 and 1948 (fig. 32) served as an impetus to the development and formation of the Central and South Florida Flood Control Project and District, established in 1949. Known as the "Comprehensive Plan," the U.S. Army Corps of Engineers initiated a major construction project in an effort to harness the "erratic" nature of the southern Florida Everglades (fig. 33). The project was designed to remove flood waters rapidly, provide surface-water storage for regional water supply, prevent canal overdrainage and saltwater intrusion, protect developed land, supply water to Everglades National Park, help preserve fish and wildlife, and serve recreational and navigational needs. The Central and South Florida Flood Control District was the predecessor of the South Florida Water Management District, which formed in 1972 when the State of Florida established five water-management districts to manage regional water resources and protect the environment.

Canal and levee construction expanded greatly during the 1950s and 1960s. (fig. 34). Major canals were enlarged and an eastern protective levee was built during the 1950 s to protect urban and eastern agricultural lands. Prior to the 1950s, U.S.

Highway 27 served as a north-south protective levee system; however, it proved to be ineffective during the 1947 flood (Merritt, 1996a, p. 19). 


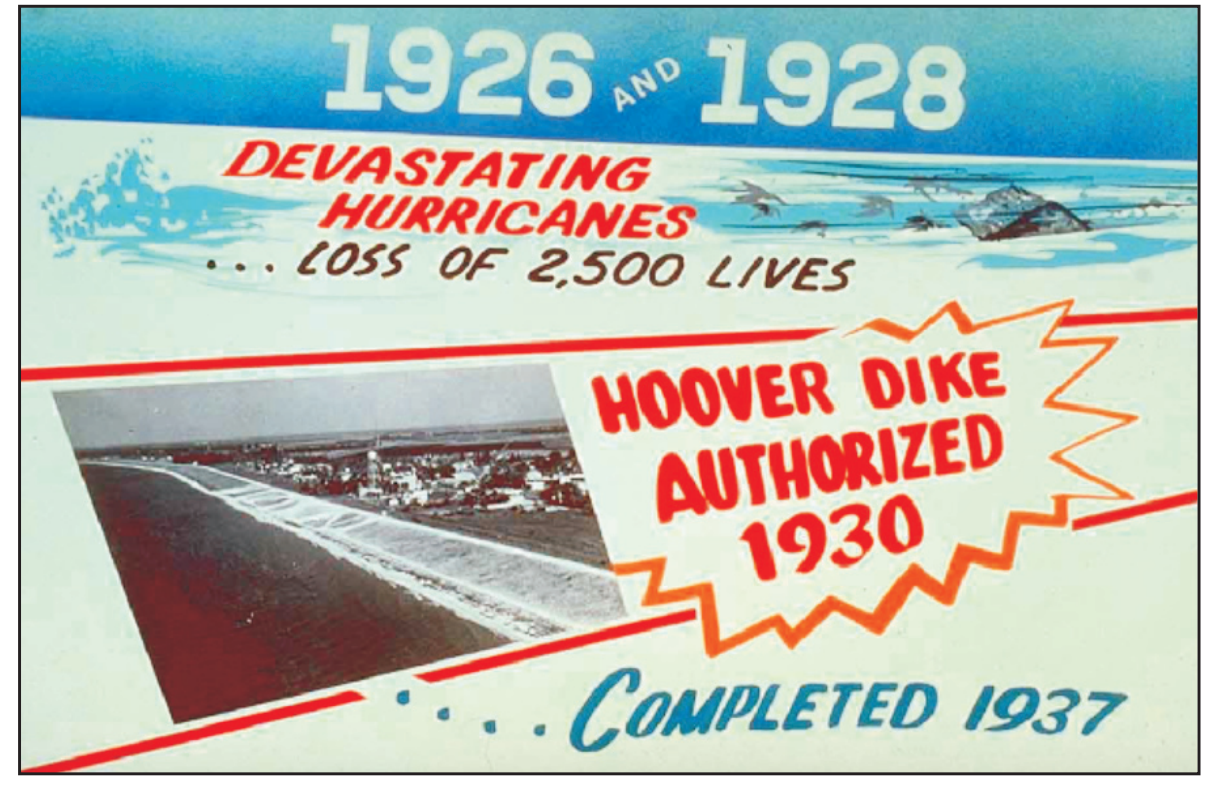

Figure 31. Poster announcing the historic completion of Hoover Dike at Lake Okeechobee. Courtesy of the South Florida Water Management District photographic archives.

During the latter half of the 1950s, canals, levees and control structures were constructed on the southern side of Lake Okeechobee to form the Everglades Agricultural Area (fig. 34B). The storage of surface water was accomplished by developing water-conservation areas during the 1960s (fig. 34B) in which water was held within sawgrass prairie areas. These conservation areas were designed to: (1) help delay runoff and prevent the overland flow of flood waters into urbanized areas; (2) control seepage to the surficial aquifer system; (3) supply recharge to well fields; (4) maintain stage levels within canals and water levels in the surficial aquifer system; (5) limit saltwater intrusion during drought periods; and (6) control the southward flow of water to Everglades National Park.

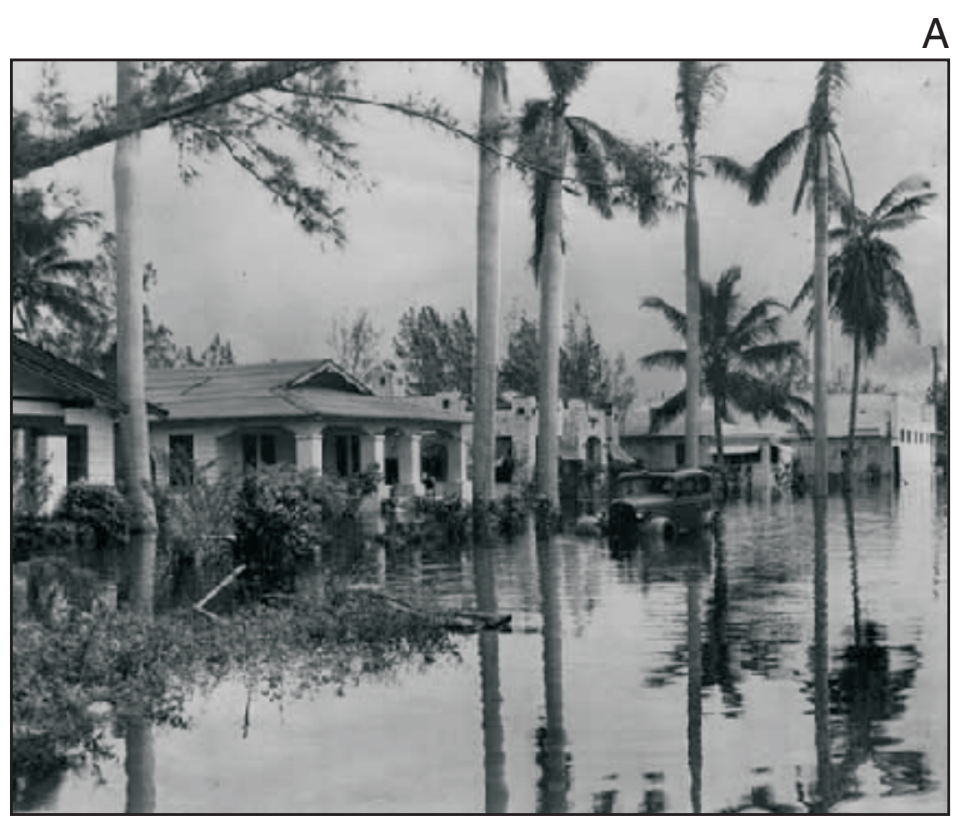

B

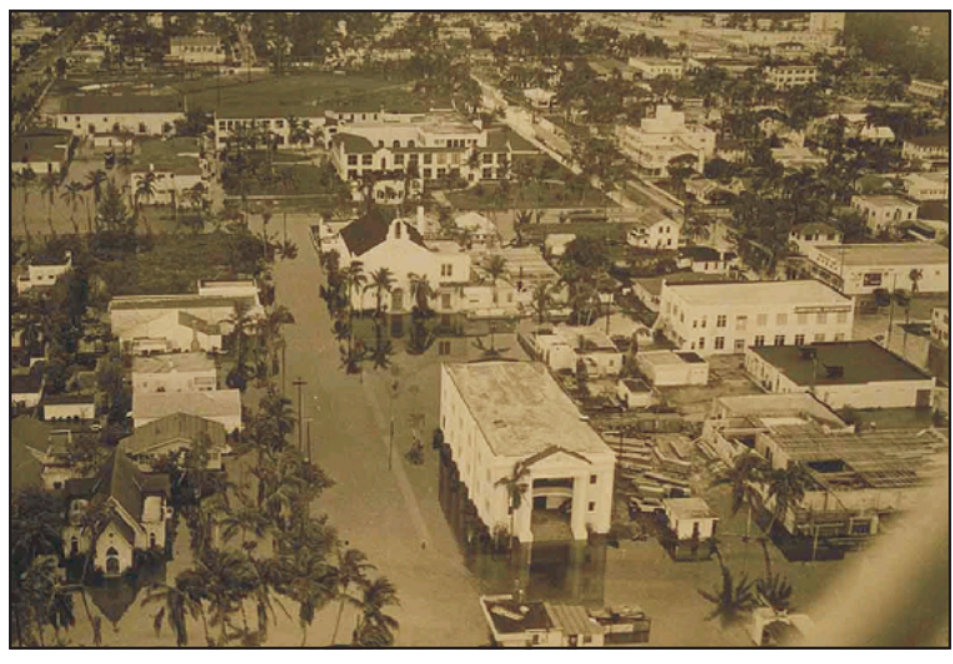

Figure 32. Photographs showing extensive flooding in $(A)$ Hialeah and $(B)$ Fort Lauderdale caused by major hurricanes that hit southeastern Florida in 1947 and 1948, respectively. 


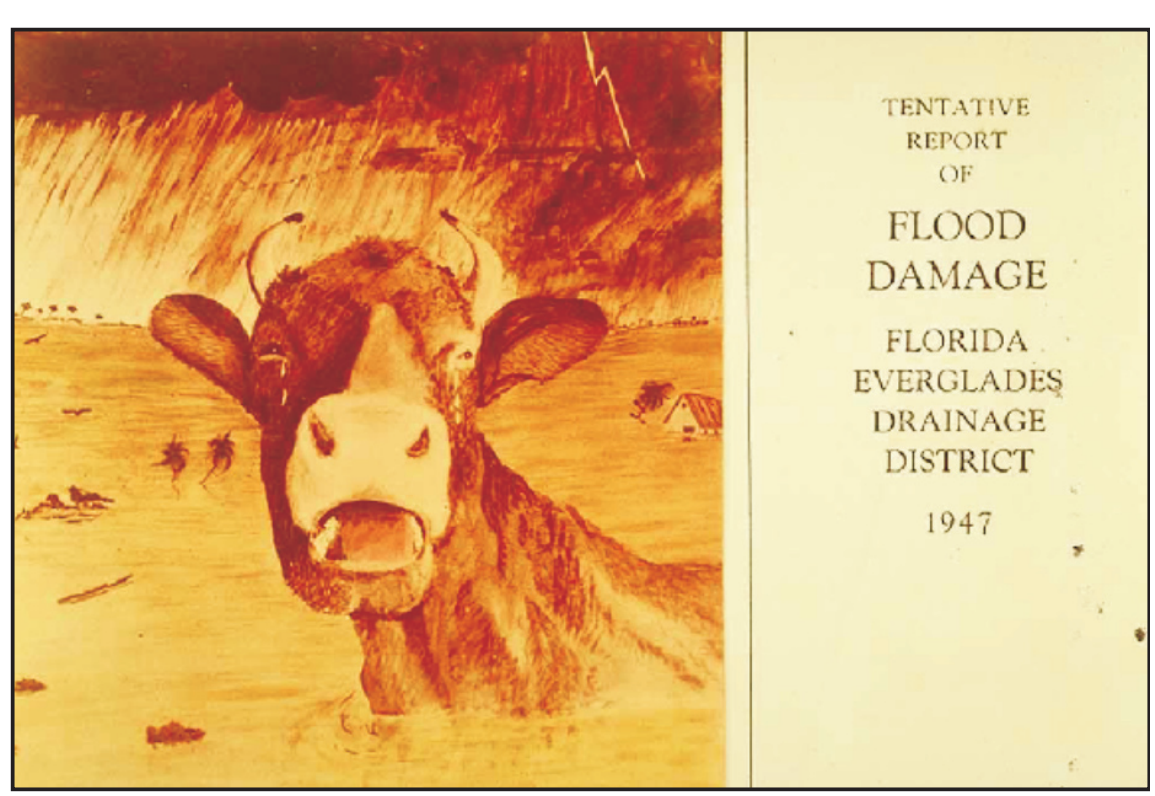

Figure 33. Photograph showing the "weeping cow." The illustration was used to dramatize the severity of flood conditions and to emphasize the need to develop a comprehensive water-management plan for southern Florida. Courtesy of the South Florida Water Management District digital photographic archives.

Additional changes in the surface-water conveyance system were made in the 1970s (fig. 35A) to meet the hydrologic needs of the park. By the 1970s, gated control structures were installed at the coastal end of the primary canals to discharge excess water during the wet season, and retard the landward movement of saltwater during the dry season (fig. 36). Secondary controls on the inland reaches of canals were installed to regulate flow eastward, control inland and agricultural flooding, and maintain higher water levels in the surficial aquifer system where appropriate. Surface-water pump stations in the Everglades Agricultural Area were added to regulate water levels for agricultural purposes, and new municipal well fields were either constructed or expanded. Canal system development reached its final phase in the 1980s (fig. 35B) with completion of the Everglades-South Dade conveyance system, which was constructed to meet agricultural water-supply needs, control flooding, and mitigate saltwater intrusion.

\section{Water-Table Fluctuations of the Surficial Aquifer System}

The surficial aquifer system generally is considered to contain water under unconfined or water-table conditions. Discharge occurs by seepage to canals, the Atlantic Ocean, and evapotranspiration. Canal seepage has a major effect on water levels due to the highly transmissive nature of the surficial aquifer system in southeastern Florida. Canals display both gaining or losing flow characteristics depending on whether ground water is discharged from the surficial aquifer system to canals or surface water in canals seeps into the aquifer system (fig. 37). Ground-water levels are highest near the impounded water-conservation areas and lowest near the coast; consequently, the hydraulic gradient in southeastern Florida is seaward and discharge to the Atlantic Ocean occurs near the coast, except under extreme drought conditions in Miami-Dade County (Schroeder and others, 1958; Sherwood and Klein, 1963).

For this study, a comparative analysis of average water-table conditions was used to evaluate temporal and spatial changes in the flow system resulting from drainage of the former wetland areas by a surface-water conveyance system. "Average-condition" maps were prepared to illustrate the evolution of the watermanagement system and its impact on the configuration of the water table in southeastern Florida. The major features of the flow system in the surficial aquifer system, illustrated in a series of potentiometric surface maps showing average conditions between 1940-44, 1970-74, and 1990-94 (figs. 38-40), were prepared using groundwater level and stage data from the files of the USGS, SFWMD, and the LWDD. In southeastern Florida, water levels are highest in September or October (end of wet season) and lowest during April or May (end of dry season). Instead of portraying synoptic conditions, a 5-year interval of time was used to dampen or smooth the effect of unusually wet or dry months.

\section{Predevelopment Water-Table Conditions and Ground-Water Flow}

Few data are available to evaluate the configuration of the predevelopment water table at the beginning of the $20^{\text {th }}$ century, and only limited data document conditions prior to 1939. The water table probably formed a subtle reflection of Atlantic Coastal Ridge topography, with stage levels in the adjoining Everglades of sufficient height to discharge surface water through the intervening transverse glades. In Miami-Dade County, Everglades wetland areas were reported to lie within 3 mi of the coastal community of Coconut Grove (fig. 15B) in 1887 (Shaler, 1890), with a reported surface-water stage of $10 \mathrm{ft}$ above NGVD 29 (Parker and others, 1955, p. 580). In Palm Beach County, historic surface-water outflows from marsh areas exited along the Loxahatchee-Hungryland Sloughs or from an outlet of the Hillsboro Marsh (Land and others, 1973). Fresh ground water discharged along the Atlantic Coastal Ridge 


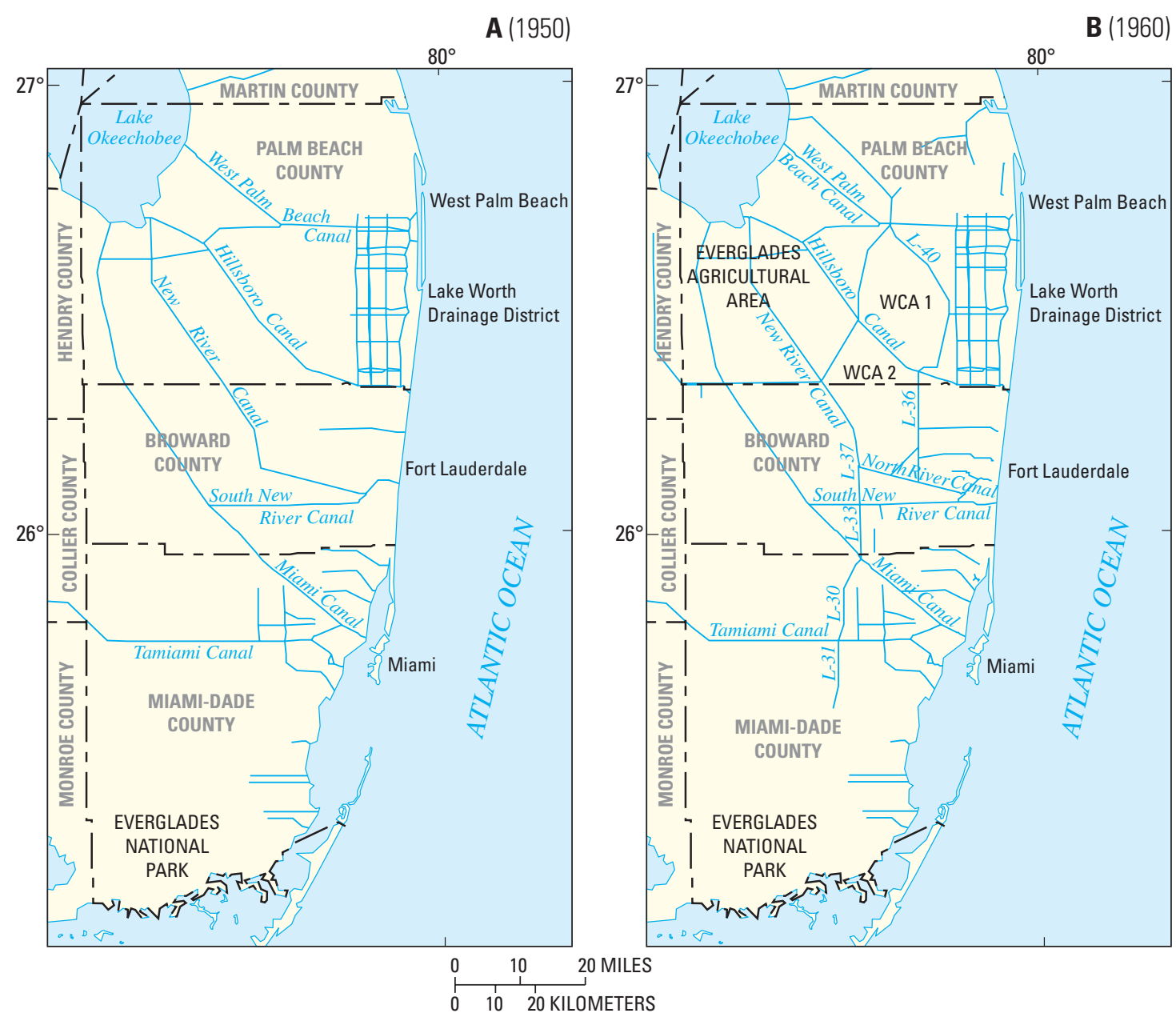

Figure 34. Surface-water conveyance system in Miami-Dade, Broward, and Palm Beach Counties in (A) 1950 and (B) 1960. Modified from data and files of the South Florida Water Management District, U.S. Army Corps of Engineers, and U.S. Geological Survey. 


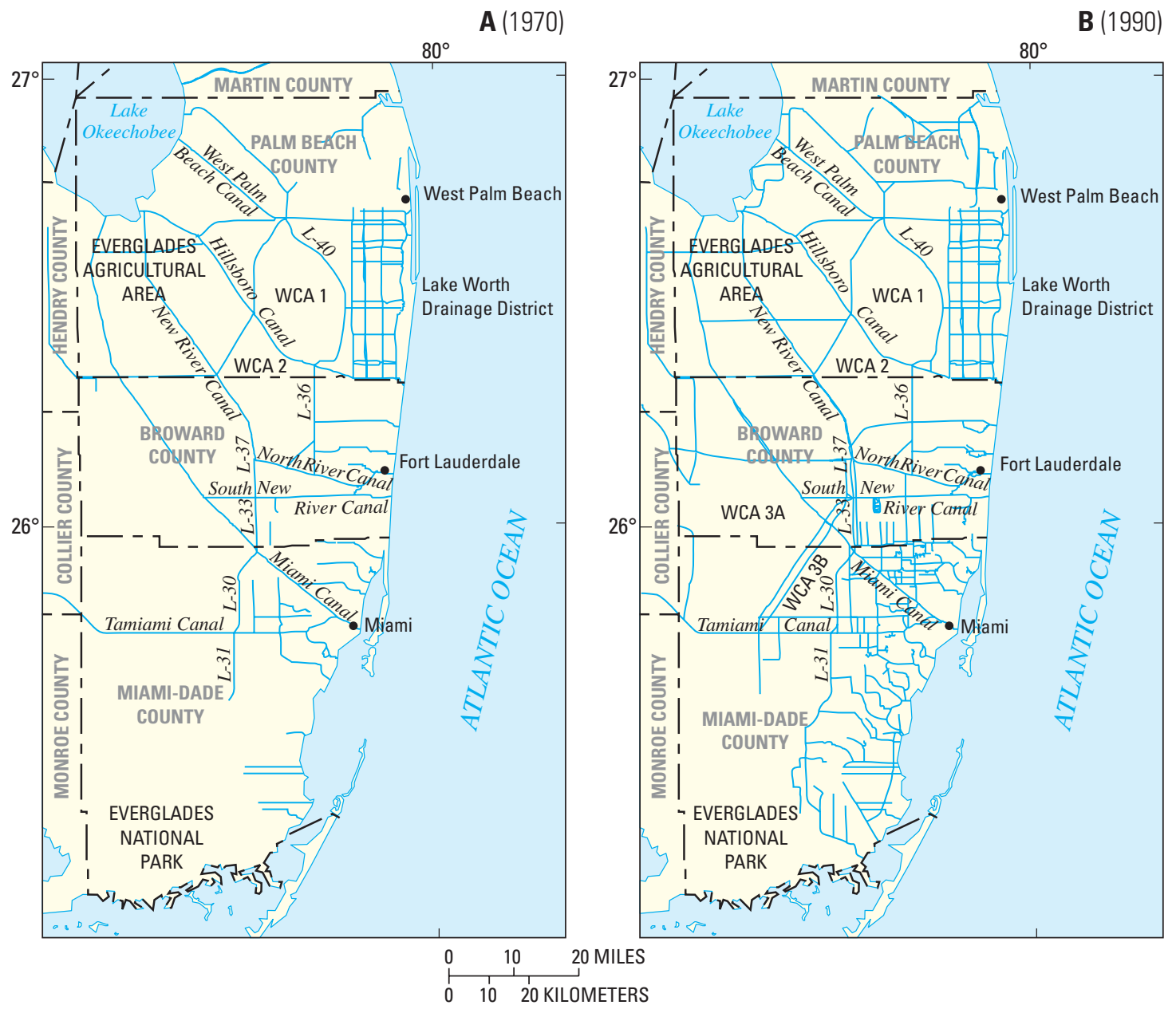

Figure 35. Surface-water conveyance system in Miami-Dade, Broward, and Palm Beach Counties in $(A) 1970$ and $(B) 1990$. Modified from data and files of the South Florida Water Management District, U.S. Army Corps of Engineers, and U.S. Geological Survey. 


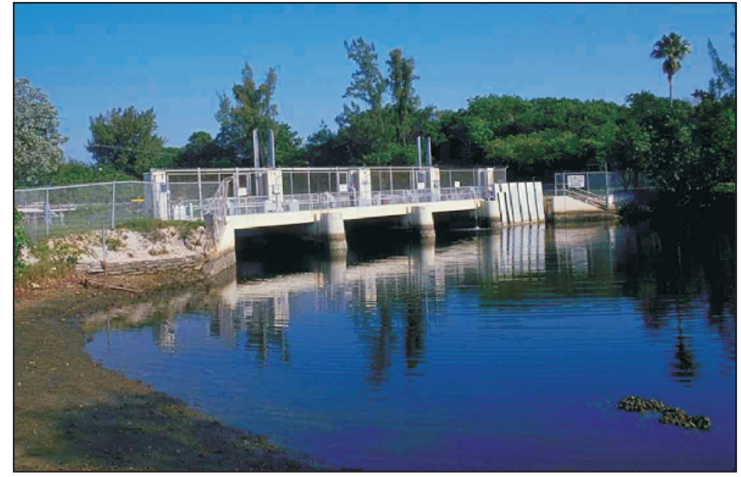

Figure 36. Gated coastal control structure at the eastern end of Snake Creek Canal. Photograph courtesy of the South Florida Water Management District digital photographic archives.

shoreline and offshore as submarine springs. Springs reportedly discharged nearshore as freshwater boils in the shallow waters of Biscayne Bay; freshwater discharge in some areas occurred in sufficient quantities to permit mariners to collect fresh drinking water directly from the bay in a boat (fig. 41B). Discharging freshwater springs were labeled on the U.S. Coast and Geodetic Survey (1896) map of Biscayne Bay (Parker and others, 1955, Kohout and Kolipinski, 1967).

Peat and muck deposits were an extremely important predevelopment component of Everglades surface- and ground-water hydrology. These deposits functioned as a storage reservoir to a water column that extended upward from the underlying aquifer, helping to maintain a higher water table and to prolong the hydroperiod (U.S. Department of the Interior, 1969; Stephens, 1984). Assuming peat deposits were fully saturated during predevelopment conditions, the combined height of the water column contributed largely to coastal ground-water hydrology, thereby restricting movement of a coastal saltwater interface. The SFWMD's Natural Systems Model, a two-dimensional coupled surface- and ground-water flow model designed to simulate predevelopment response of the Everglades system (MacVicar and others, 1984), provides some insight to possible predevelopment ground-water flow conditions. Simulated hydraulic gradients were greatest near the Atlantic

Coastal Ridge with ground water flowing to the coast and to the west (Fennema and others, 1994).

\section{Average 1940-44 Water-Table Conditions}

The April and October 1940-44 maps (fig. 38) show conditions in the surficial aquifer system before the extensive, modern-day drainage and conveyance system was developed as part of the Central and Southern Florida Flood Control Project of the 1950s and 1960s. The five major canals (St. Lucie, West Palm Beach, Hillsboro,
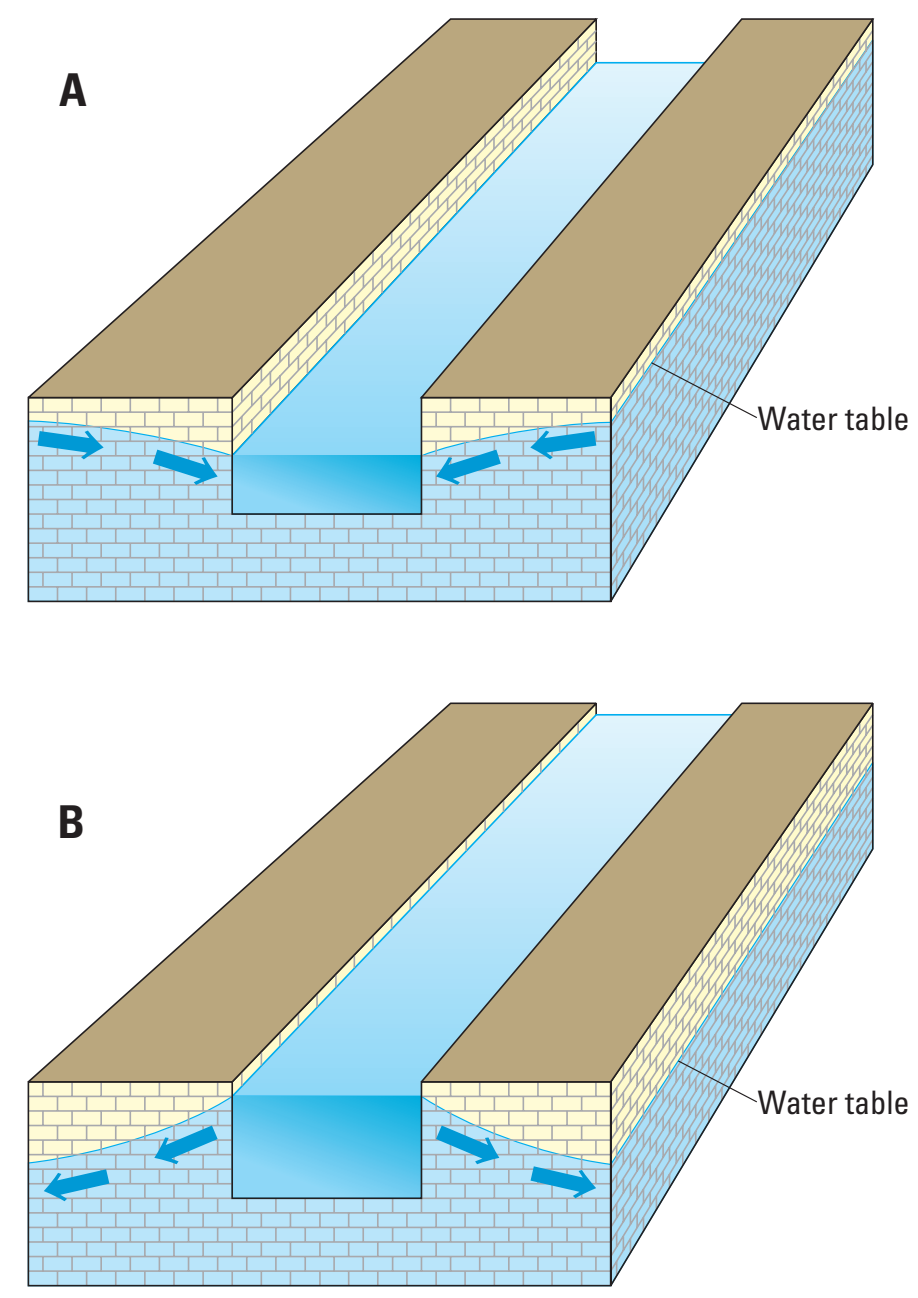

Figure 37. Canals of southern Florida exhibiting both $(A)$ gaining and $(B)$ losing characteristics depending on relative stage level. Modified from Klein and others (1975). 

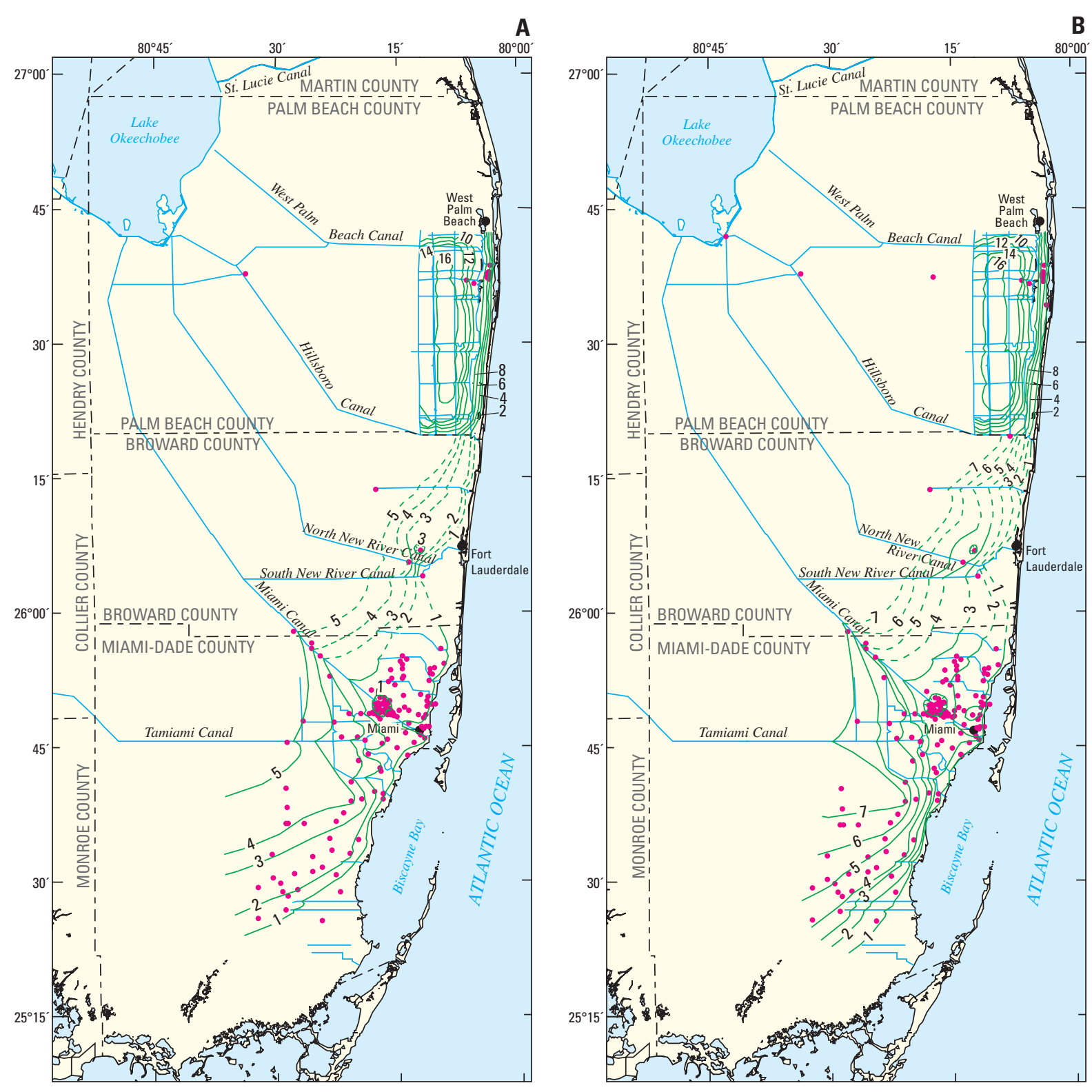

\section{EXPLANATION}

- 3 - UINE OF EOUAL WATER LEVEL-Interval is 1 and 2 feet. Dashed where

approximate. Hachure indicates cone

of depression. Datum is NAD 1927

- WELL CONTROL POINT

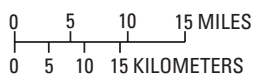

Figure 38. Average water levels in the surficial aquifer system in southeastern Florida during (A) April 1940-44 and (B) October 1940-44. Derived from data and files of the U.S. Geological Survey, South Florida Water Management District, and Lake Worth Drainage District. 
A
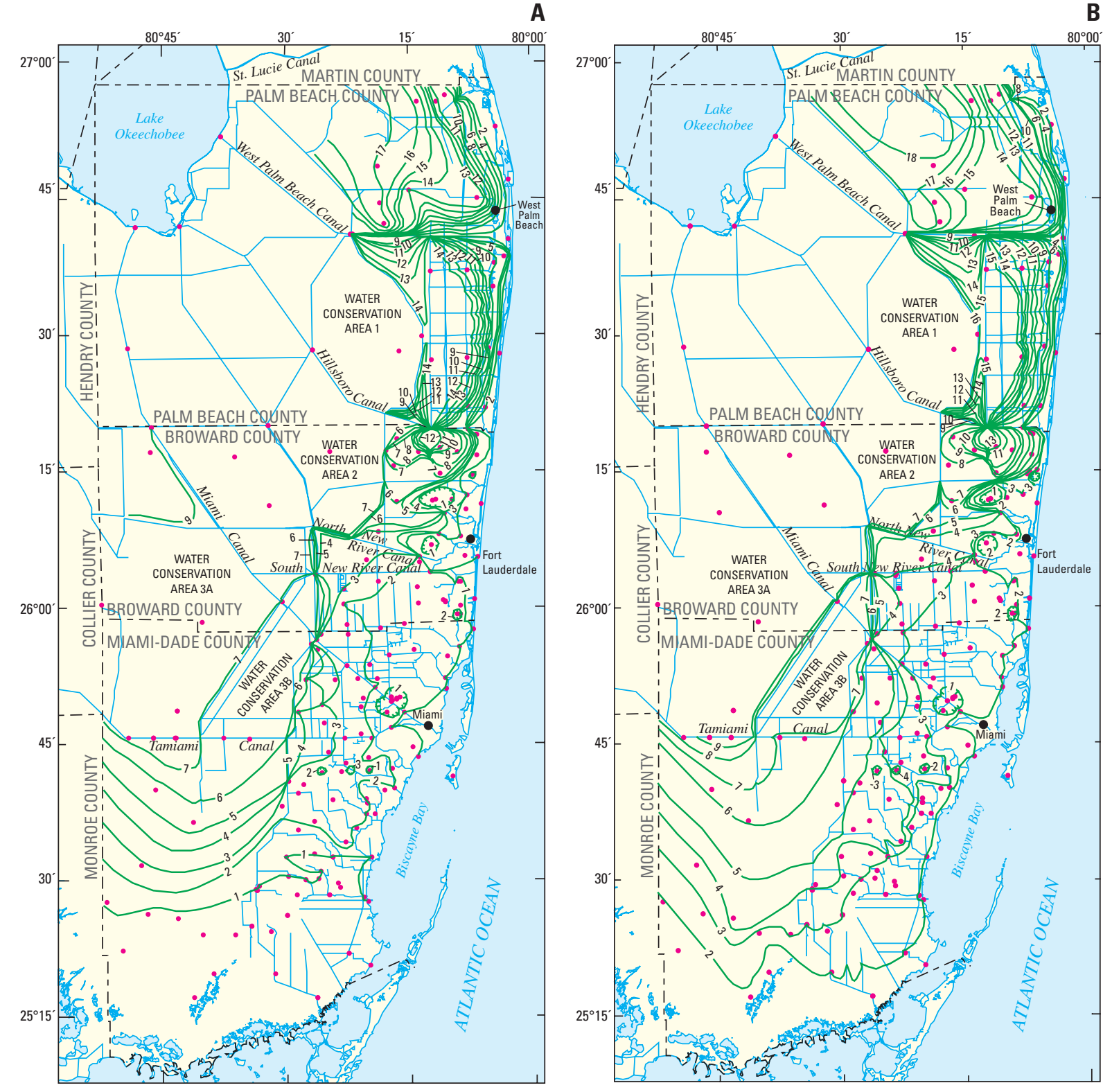

Figure 39. Average water levels in the surficial aquifer system in southeastern Florida during $(A)$ April 1970-74 and (B) October 1970-74. Derived from data and files of the U.S. Geological Survey, South Florida Water Management District, and Lake Worth Drainage District. 

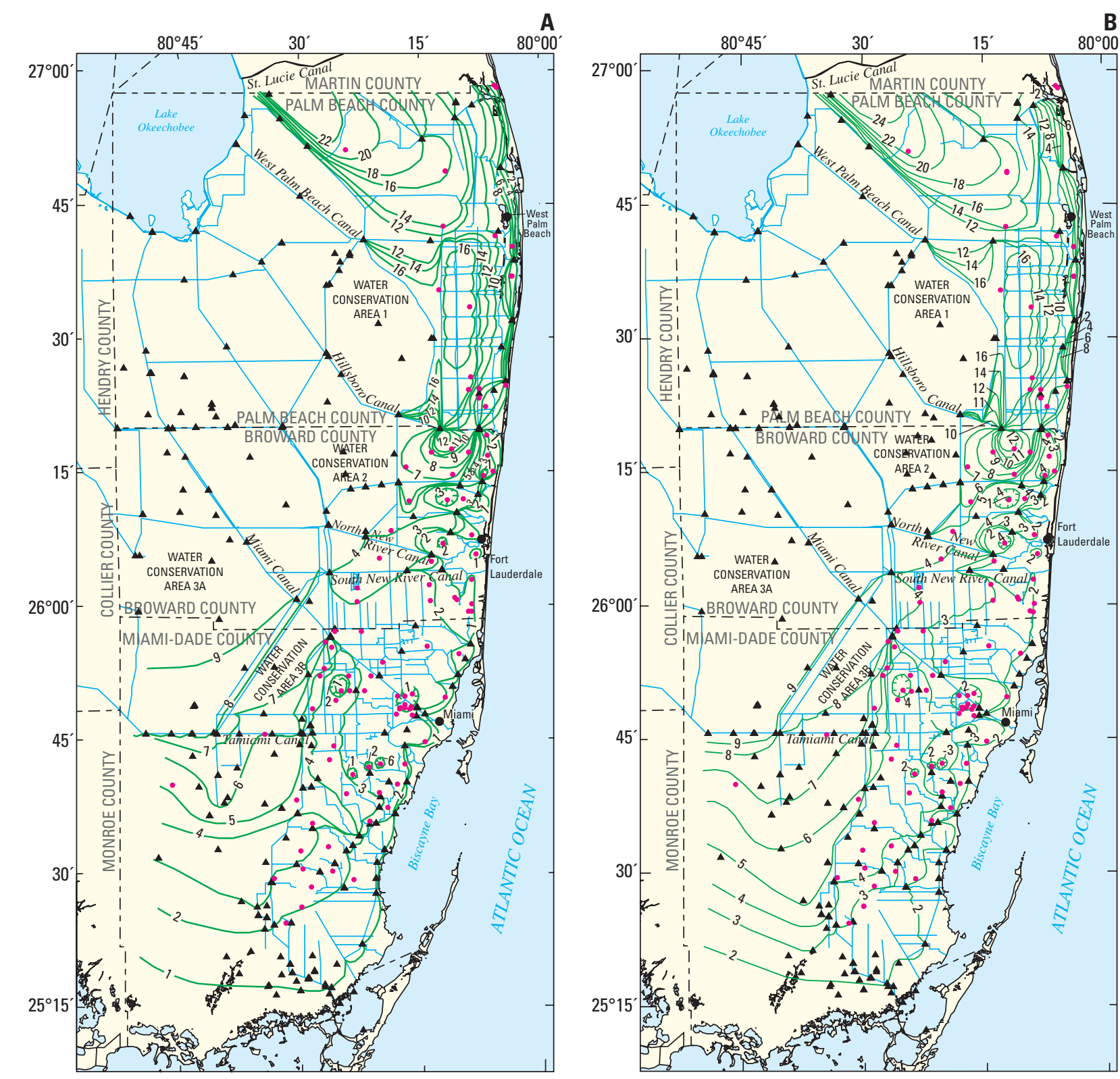

\section{EXPLANATION}

— 3 - LINE OF EQUAL WATER LEVEL-

Interval is 1 and 2 feet

Hachures indicate cone of

depression. Datum is NAD

1927

- SURFACE-WATER CONTROL

POINT

- WELL CONTROL POINT

\section{$\stackrel{0}{0} \quad 5 \quad 10 \quad 15$ MILES

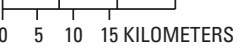

Figure 40. Average water levels in the surficial aquifer system in southeastern Florida during $(A)$ April 1990-94 and

(B) October 1990-94. Derived from data and files of the U.S. Geological Survey, South Florida Water Management District, and Lake Worth Drainage District. 
North New River, and Miami Canals) that extend from Lake Okeechobee to the southeastern coast and the Tamiami Canal were the largest existing man-made hydrologic features. Smaller and less extensive canal systems also were present in Miami-Dade and Palm Beach Counties. An extensive levee system, gated canal structures along the coast to prevent saltwater intrusion, and impoundment structures had not yet been built.

Everglades drainage efforts remained uncontrolled through the early 1940s, causing a lowering of water levels in the surficial aquifer system underlying the Atlantic Coastal Ridge, wetland areas adjoining the ridge, and along major drainage canals. The uncontrolled drainage contributed to movement of saline water into canals and the surficial aquifer system. The lowest water levels in the surficial aquifer system, recorded in 1945, were attributed to the combined effect of long-term uncontrolled canal drainage and an extended drought (Schroeder and others, 1958, fig. 14)

South of the Tamiami Canal in Miami-Dade County, ground water discharged to the east and southeast; an eastward hydraulic gradient characterized the water table between the Tamiami and Miami Canals. The highest reported water levels between 1939 and 1946 were on September 23, 1940, along the Atlantic Coastal Ridge between the Tamiami and Miami Canals (Parker and others, 1955, p. 211). The water table formed a large mound with ground-water movement toward both the Everglades and the coast.

A cone of depression adjoining the Miami Canal surrounded the City of Miami Well Field during the early 1940s. Now referred to as the Hialeah-Miami Springs Well Field (fig. 18, Miami-Hialeah), its primary source of recharge was the Miami Canal. The LWDD in Palm Beach County generally maintained higher water levels than those in Broward and Miami-Dade Counties (Parker and others, 1955, p. 173). Sparse water-level control points limited analysis of conditions during the 1940-44 time frame north of the LWDD.

\section{Average 1970-74 Water-Table Conditions}

The 1970-74 water-table maps (fig. 39) represent average hydrologic conditions in the surficial aquifer system following completion of the Central and Southern Florida Flood Control Project. Engineered features that affected the altitude and configuration of the water table in the surficial aquifer system during this period include coastal gated canal structures, extensive levees and surface-water impoundments (water-conservation areas), pump systems, improved secondary canals, and the construction/expansion of several large well fields. By the 1970s, hydraulic gradients were greatest near landward conservation areas (Fennema and others, 1994), whereas the lower ground-water levels and shallower coastal hydraulic gradients increased potential for saltwater intrusion (Leach and others, 1972).

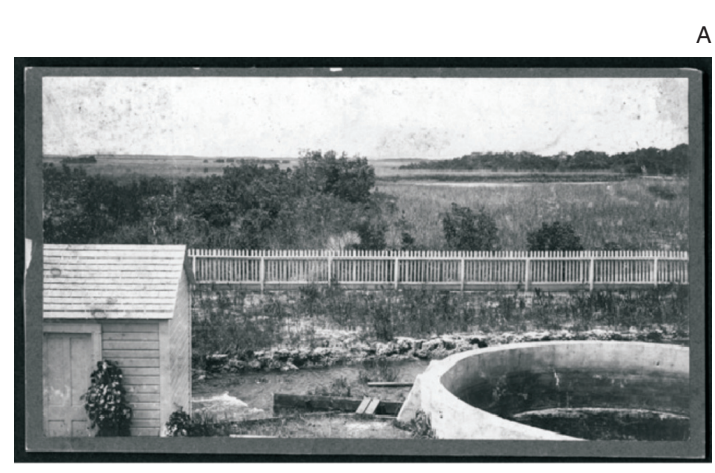

B

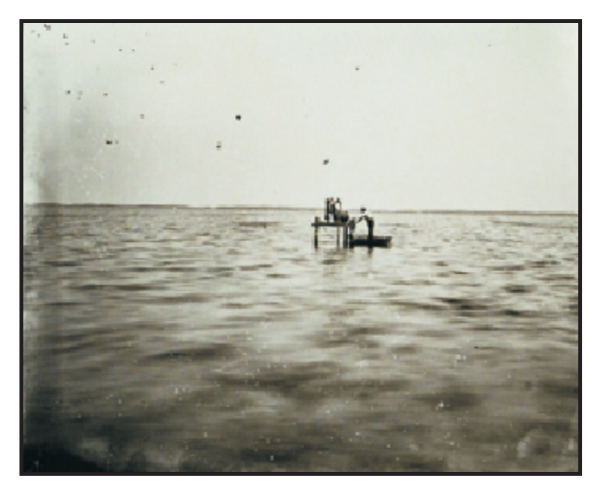

The highest water levels in Miami-Dade County typically occurred in the waterconservation areas. South of the Tamiami Canal, the hydraulic gradient was predominately to the south and southeast, whereas north of the Tamiami Canal, the hydraulic gradient was eastward. In Broward County, water was diverted from major canals by free flow or was pumped into local canals to maintain water levels in the surficial aquifer system, and to artificially recharge local well fields by canal seepage. Water levels were highest in Broward County near the water-conservation areas and also in the northeastern part of the county (fig. 39). In the latter area, surface water was pumped from the Hillsboro Canal into secondary canals, creating an artificial mound (Fish, 1988, p. 68). A steep hydraulic gradient separated this mound from the northwestern edge of the Prospect Well Field (fig. 19).

In Palm Beach County, water levels were highest in Water Conservation Area 1, the LWDD, and the northwestern part of the county (figs. 35 and 39). Gated canals and lateral canals maintained 16-ft-high water levels in the LWDD. These multipurpose canals were used to drain excess surface water during the wet season, maintain water levels in the surficial aquifer system, and minimize saltwater intrusion caused by coastal well withdrawals. 
Closed depressions in the water-table surface evident in the 1970-74 maps (fig. 39) and also the 1990-94 maps (fig. 40), discussed next, are attributable to large water withdrawals from municipal well fields in Miami-Dade and Broward Counties. These cones of depression are associated with withdrawals from the Miami-Hialeah, Alexander Orr, Southwest, Northwest, Dixie, Prospect, and Pompano Beach Well Fields (figs. 19 and 20). Withdrawals from other smaller well fields, including those in Broward and Palm Beach Counties, have resulted in similar but smaller hydrologic features not evident on the water-table maps of this scale.

\section{Average 1990-94 Water-Table Conditions}

By 1990-94, a water-management system had evolved to include hydraulic control structures and a system of levees, impoundments, and gated conveyance canals that collectively affected the altitude and configuration of the water table. The 1990-94 water-table maps (fig. 40) illustrate average conditions during a dryseason month (April) and wet-season month (October). The overall configuration of the water table in the surficial aquifer system is similar to that seen for average conditions during 1970-74 (fig. 39). For example, the highest water levels are maintained in the water-conservation areas, and the movement of ground water is east and southeast toward the coast. In Miami-Dade County, withdrawals from the Northwest Well Field (fig. 20), constructed in the early 1980s, helped to lower water levels. Well-field withdrawals are in evidence by the occurrence of a cone of depression not previously seen. The Northwest Well Field was built as an alternative municipal water supply following contamination concerns associated with Hialeah-Miami Springs supply wells. Withdrawals were curtailed in the Hialeah-Miami Springs Well Field from 1984 to 1992 (Sonenshein and Koszalka, 1996), but reinitiated following the completion of a new treatment facility.

Withdrawals from the Northwest Well Field have been subsequently reduced.

The configuration of the potentiometric surface in Broward County in 199094 (fig. 40) is largely the same as in 1970-74 (fig. 39). Prior to 1985, agricultural users in the Deerfield Beach area relied on water pumped from the Hillsboro Canal to supply irrigation canals, also helping to recharge the surficial aquifer system. In northwestern Palm Beach County, water levels exceeding $20 \mathrm{ft}$ were maintained. Stage levels in Water Conservation Area 1 and the LWDD canals (fig. 35) were both greater than $16 \mathrm{ft}$ during the wet and dry seasons. An increase in municipal and domestic withdrawals, combined with regulatory change in canal stage, have cumulatively affected the altitude and configuration of the water table in Palm Beach County (Miller, 1988, p. 190). The City of Boca Raton withdraws water from the Hillsboro Canal to maintain coastal ground-water levels, prevent saltwater intrusion, and recharge the surficial aquifer system in the vicinity of the city's western well field (McKenzie, 1995).

\section{Ground-Water Level Changes Over Time}

Temporal and spatial water-level changes that have occurred during the last 60 years of the $20^{\text {th }}$ century are depicted in figures 42,43 , and 44 . Specifically, these maps spatially portray "5-year average" temporal water-level differences that occurred between 1940-44 and 1990-94, 1940-44 and 1970-74, and 1970-74 and 1990-94 during April (dry season) and October (wet season).

Average ground-water levels declined in large inland areas in April 1990-94 and October 1990-94 in comparison to those conditions observed in April 1940-44 and October 1940-44 (fig. 42). The water-level declines are attributable to water-management drainage efforts to control urban and agricultural flooding. The departure in monthly mean average dry-season precipitation from normal conditions in April 1940-44 and 1990-94 and the prior months was similar in magnitude (fig. 45). This contrasts considerably with the departure from normal wet-season (October) rainfall that was considerably below average in 1940-44 when compared to 1990-94. On a spatial basis, however, water levels in 1990-94 appear to have been 1 to $3 \mathrm{ft}$ lower over a wide area in Miami-Dade and Broward Counties. This spatial pattern illustrates that management controls had a far greater effect on ground-water levels than temporal rainfall patterns, and is indicative of the permanent change that occurred as part of a highly controlled drainage system infrastructure.

Average ground-water levels along the coast were higher in 1990-94 than in 1940-44, which probably is the result of long-term management efforts to reduce saltwater intrusion in the surficial aquifer system. Comparison of average water levels in 1940-44 and 1970-74 indicates similar distributions in water-level change (fig. 43). Generally, canal management and water levels in the surficial aquifer system had been established during the 1970s. The similarity in the distribution of water-level change between maps (figs. 43) suggests that management controls on water levels in the surficial aquifer system had matured by 1990-94.

A comparison of 1970-74 and 1990-94 average ground-water levels (fig. 44) shows that average dry-season ground-water levels in April 1990-94 remained constant or were only 1 or $2 \mathrm{ft}$ higher than 1970-74 ground-water levels in most of Miami-Dade and southern Broward Counties. In northern Palm Beach County, 1990-94 average wet-season ground-water levels were higher than in 1970-74, except near the coast and along a corridor between the L-8 and L-10 Canals (fig. 44).

Differences in average ground-water level conditions in northern Palm Beach County during the dry season in October 1970-74 and 1990-94 are similar to the wet-season differences observed during the same time period (fig. 44), presumably resulting from modifications that were made in water-management practices. Average dry-season water levels that occurred in the 1990s remained unchanged or were slightly lower in developed areas of Miami-Dade, Broward, and southern Palm Beach Counties. 
A
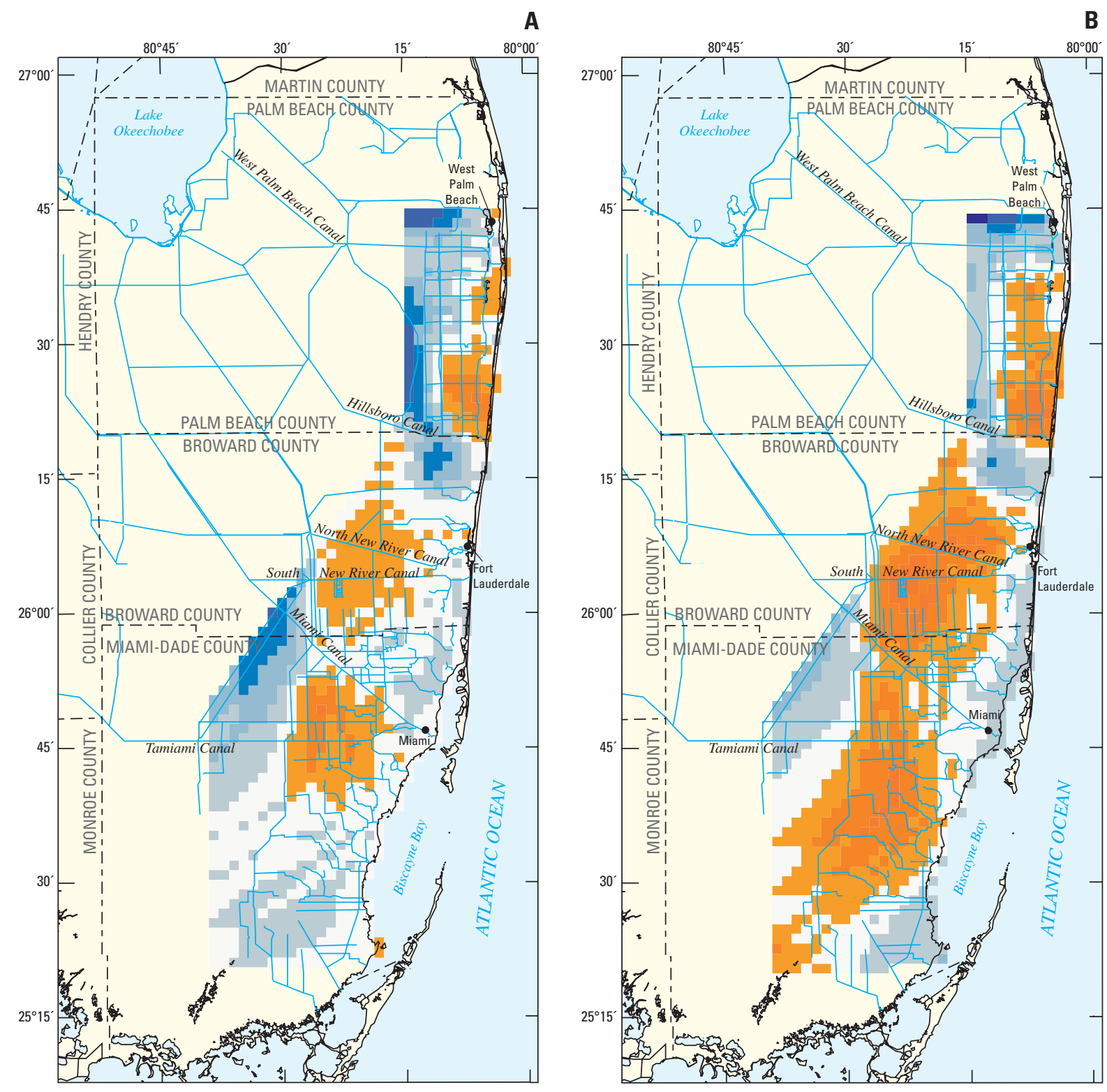

\section{EXPLANATION}

AVERAGE DIFFERENCES IN WATER LEVELS, IN FEET

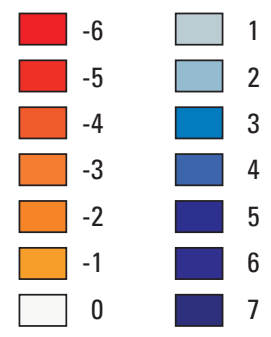

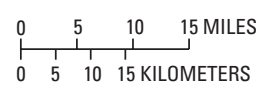

Figure 42. Average difference in water levels between (A) April 1940-44 and April 1990-94 and between $(B)$ October 1940-44 and October 1990-94. Derived from files of the U.S. Geological Survey. 

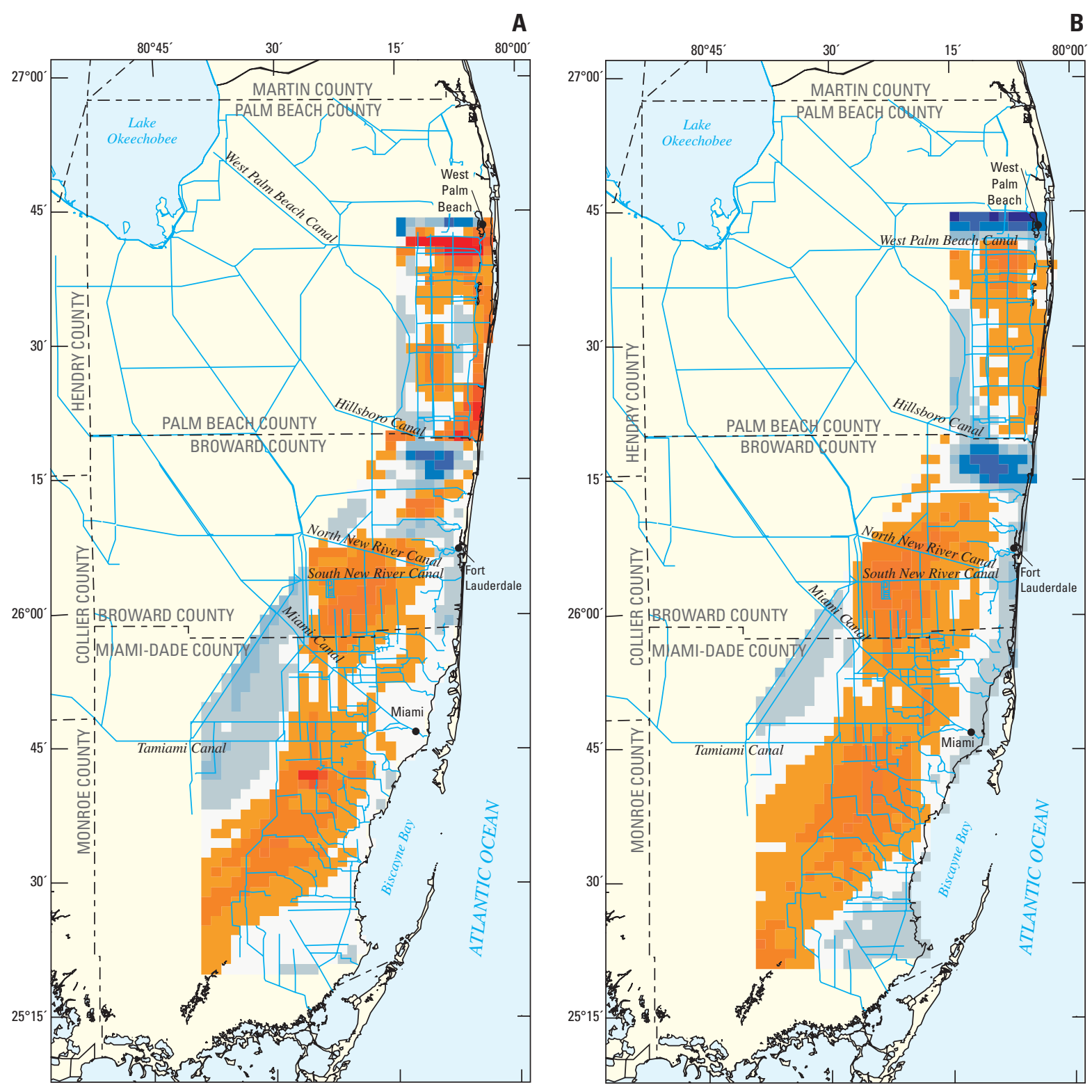

\section{EXPLANATION}

AVERAGE DIFFERENCES IN WATER LEVELS, IN FEET

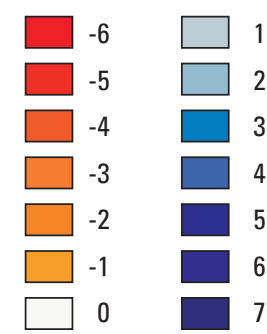

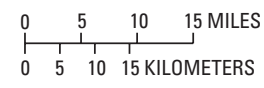

Figure 43. Average difference in water levels between (A) April 1940-44 and April 1970-74 and between $(B)$ October 1940-44 and October 1970-74. Derived from the files of the U.S. Geological Survey. 

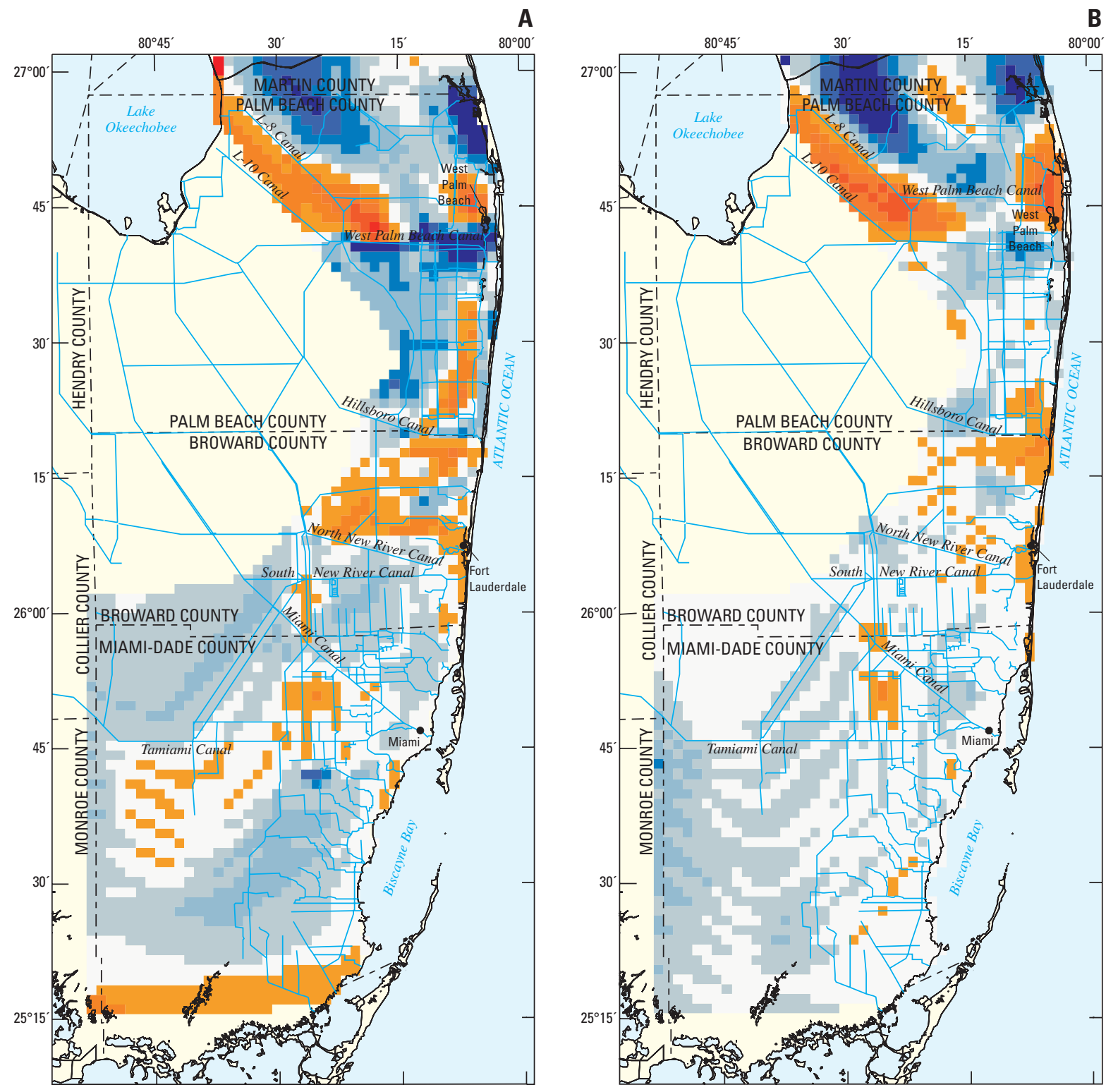

\section{EXPLANATION}

AVERAGE DIFFERENCES

IN WATER LEVELS, IN FEET
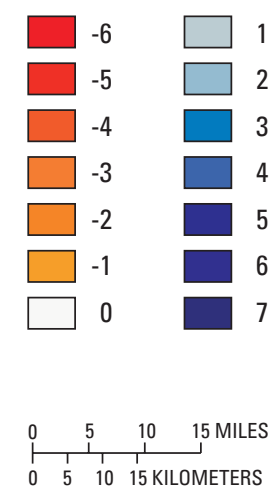

Figure 44. Average difference in water levels

between (A) April 1970-74 and April 1990-94 and between (B) October 1970-74 and October 1990-94. Derived from the files of the U.S. Geological Survey. 


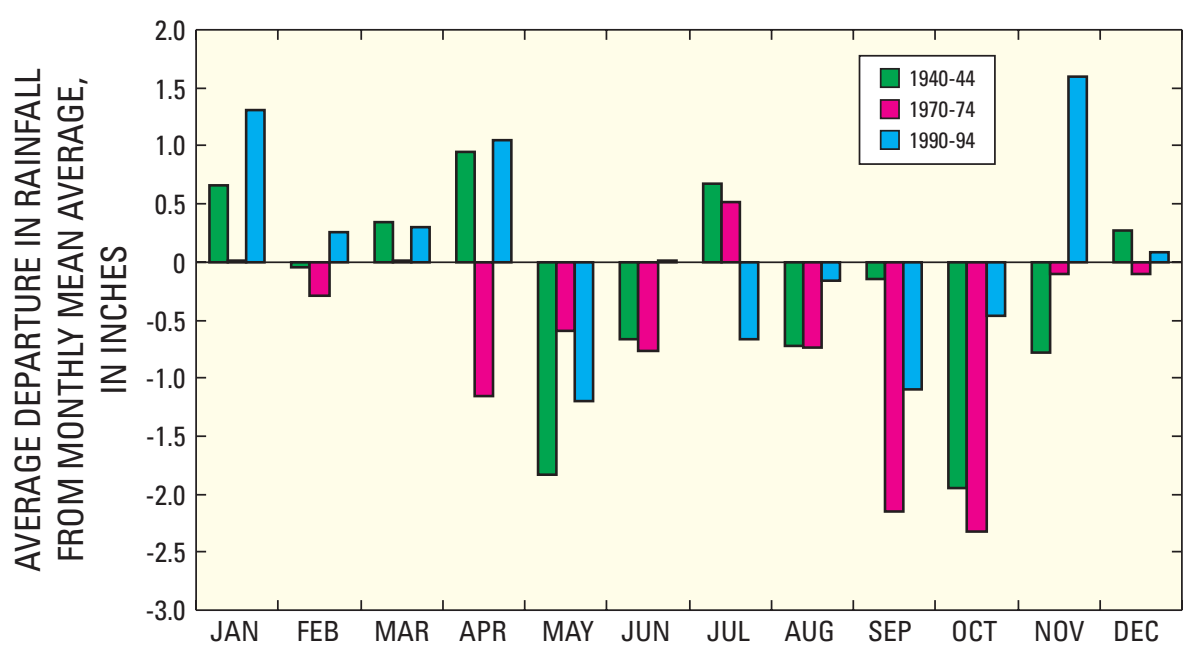

Figure 45. Average departure in rainfall from monthly mean average conditions at 14 sites in southeastern Florida. Data from the National Oceanographic and Atmospheric Administration.

The volume of water lost by long-term drainage of ground water can be estimated by multiplying storativity (specific yield), surface area of the drained aquifer, and the average decline in head (figs. 42 and 43). The specific yield of the Biscayne aquifer has been reported to range from 0.10 to 0.35 in Broward and Miami-Dade Counties (Schroeder and others, 1958), with a similar estimate that has been assumed for near-surface water-bearing rocks in Palm Beach County. About 2 to 9 billion gallons of ground water were lost permanently from the system through aquifer drainage between 1940-44 and 1970-74. A comparison of April 1940-44 and 1990-94 water levels suggests that the Biscayne aquifer lost between 1.6 and 7.4 billion gallons of water between these periods within the area shown in figures 42 and 43. This water loss only includes drainage of the Biscayne aquifer and does not include water loss resulting from reclamation of overlying wetland areas.

Short-term fluctuations in water levels in the surficial aquifer system result from daily to seasonal variations in recharge and discharge in the aquifer system. Generally, the surficial aquifer system is recharged directly by precipitation through a moderately thin soil cover or by seepage from canals that are hydraulically well connected to the aquifer system. The biannual variation in water levels in the surficial aquifer system can range from 2 to $10 \mathrm{ft} / \mathrm{yr}$ in response to seasonal (dry or wet) rainfall patterns. Ground-water levels generally are highest during the latter part of the wet season and the earliest part of the dry season (September-December). Lowest ground-water levels occur during the end of the dry season and the earliest part of the wet season (April-June). Extremely low water levels occur during lengthy periods of below-normal precipitation, or in areas that have been affected by the drawdown of municipal and agricultural wells.

Construction and completion of the Everglades-South Dade Conveyance System served to dampen the seasonal variability of ground-water levels in the 1980s. This conveyance system diminished the seasonal amplitude in ground-water levels, thereby lessening the observed water-level extremes during flood and drought conditions as seen at well S-196A (fig. 46A). Similar relations are observed in nearby well G-789 (fig. 46B).

\section{Surface-Water Discharge}

Since its inception, the canal conveyance system in southeastern Florida has had a major impact on both coastal ground-water hydrology and ecosystem ecology by increasing the flow of water from the Everglades to the Atlantic Ocean (Leach and others, 1972). This is evident in the long-term temporal variations in discharge and canal stage, which were assessed at selected surface-water sites near the coast and along the western edge of the urban-agricultural corridor (figs. 47-49). Mean monthly canal discharge and stage were averaged for the dry (November to April) and wet season (May to October) along the West Palm Beach, Hillsboro, North New River, and Miami Canals.

Observed variability in canal stage and canal flow prior to the 1960s is largely attributable to an incomplete drainage system under construction that responded directly to changes in the hydrologic system. Shallow, pre-1960s Everglades Agricultural Area canals that drained to major canals had limited capacity and were not yet regulated by control structures. Upstream areas tended to be overdrained during the wet season and lacked storage capacity during the dry season. Operational changes were put in place by the 1960 s that helped to dampen or reduce high flow rates during high runoff events and increase low flow rates during droughts. The seasonal dampening of discharge is evident in some hydrographs at coastal structures (figs. $48 B, D, F$ ).

Long-term measured discharge along the coastal reach of major canals largely declined during the latter half of the $20^{\text {th }}$ century (fig. $48 B, D, F, H$ ), whereas stage varied by season. Specifically, coastal canal stage levels (fig. 48A, $C, E, G$ ) were maintained mostly at higher levels during the dry season than during the wet season, presumably to help prevent urban flooding. Long-term wet- and dry-season canal stage along the coastal reach of the Miami River (fig. $48 G$ ) gradually increased between 1960 and 2000, possibly helping to minimize saltwater intrusion; less 

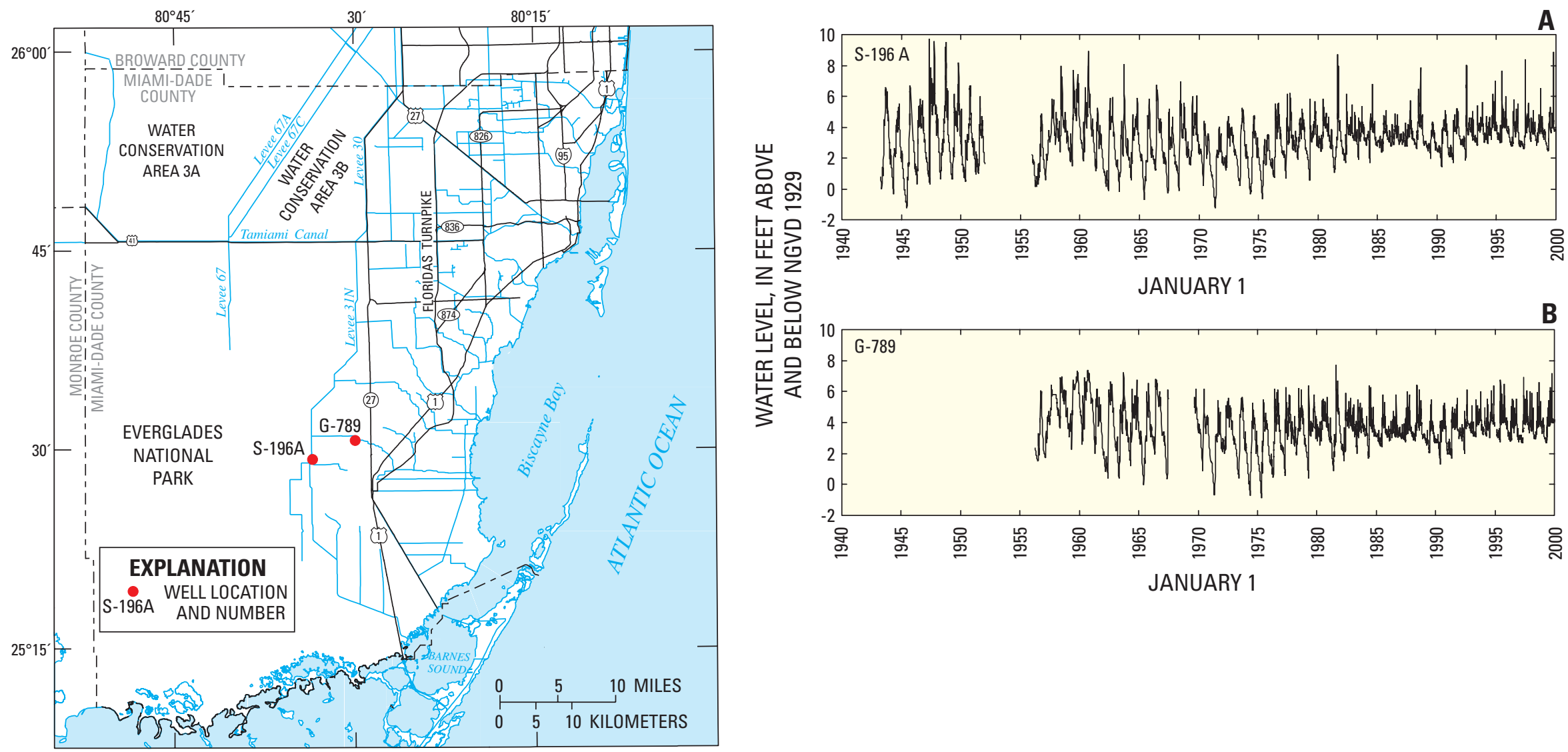

Figure 46. Dampening of variations in ground-water levels following emplacement of the Everglades-South Dade Conveyance System. Derived from the files of the U.S. Geological Survey. 
dramatic, but similar stage relations were exhibited along the coastal reach of the Hillsboro canal (fig. 48C). The long-term stage relations of the West Palm Beach and North New River Canals (fig. 48A, E) is more complex; stage was maintained at wet-season levels that gradually increased (May-October), but remained relatively stable or diminished slightly during the dry season (November-April).

Long-term flow and stage relations along the western margin and urban reach of major canals (fig. 49) are more difficult to explain than stage-discharge relations observed near the coast. Long-term flow into the urban area declined along the West Palm Beach and Miami Canals (fig. 49B, $H$ ), whereas Hillsboro and North New River Canal inflows (figs. $49 D, F$ ) were relatively consistent following emplacement of water-management controls. Conversely, long-term canal stage levels increased along the western urban reach of the Hillsboro and North New River Canals (figs. 49C, E), but decreased along the West Palm Beach and Miami Canals (figs. 49A, $G$ ).

The decrease in canal discharge within urban areas may be from municipal ground-water withdrawals that have helped to induce canal recharge. Withdrawals from the surficial aquifer system in Miami-Dade, Broward, and Palm Beach Counties increased from 85 to $770 \mathrm{Mgal} / \mathrm{d}$ in 1940 and 1995, respectively. Urban canal discharge decreases also may be due to the rerouting of surface-water flow to secondary canals, such as the LWDD (fig. 35). The rerouting is designed to elevate local coastal ground-water levels or recharge local well fields by canal seepage.

\section{Assessment of Saltwater Intrusion}

Under predevelopment conditions, the freshwater-saltwater interface in southeastern Florida extended close to the coastline, and freshwater was discharging from springs on the floor of Biscayne Bay, where the aquifer extends and is hydraulically connected to the Atlantic Ocean (Parker and others, 1955). The natural balance between freshwater and saltwater was first altered following the emplacement of canal drainage works accompanied by the oxidation and compaction of peat soils that functioned as a sponge, helping to maintain higher ground-water levels in the underlying aquifer. Designed to control deadly catastrophic flooding in the late 1920s, completion of the protective Hoover Dike at Lake Okeechobee in 1937 signaled the demise and subsidence of a large natural peat storage reservoir, funneling surface water into narrow channels that debouched surface water at the coastline. Natural overland flow processes served to supply water to the surficial aquifer system; however, once severed, saltwater intrusion issues accelerated. Although ground-water movement extends into the shallow surface marine environment, as recently documented in southern Biscayne Bay between Coconut Grove and Homestead (Langevin, 2001), only a limited part of the present-day submarine ground-water discharge to Biscayne Bay is fresh-most is recirculated seawater (Kohout and Kolipinski, 1967, Langevin, 2001).

Saltwater intrusion has been an issue of concern in southeastern Florida since the early 1930s, with its most severe effect evident during the 1940s. Following a lengthy drought and prolonged period of uncontrolled drainage, the water supply in Miami-Dade County experienced its greatest threat by saltwater contamination in May-June 1945, also recording its lowest water levels (Leach and others, 1972). Uncontrolled drainage of the Everglades, peat and muck soil loss due to oxidation-compaction processes, associated lowering of the water table within the peat mantle and underlying surficial aquifer system, and coastal well-field withdrawals have collectively contributed to the landward advance of saltwater in the surficial aquifer system as exemplified along the coastal reach of the Miami Canal. Saltwater intrusion concerns of the 1930s and 1940s centered mostly on contamination of the Miami-Hialeah Well Field (fig. 18) and other private wells for agricultural supply with little regard to the impact on the local ecology. In Broward County, saltwater intrusion became an issue during the drought of 1945-46 (Parker and others, 1955, p. 677) because of tidal canal seepage near the Fort Lauderdale (Dixie) Well Field (fig. 18).

The mechanics and character of saltwater intrusion in the surficial aquifer system in southeastern Florida have been evaluated extensively in previous studies. Some of the researchers include Parker (1945), Parker and others (1955), Klein (1957), Kohout (1960; 1964), Cooper (1959), Leach and others (1972), Hughes (1979), Klein and Waller (1985), Koszalka (1995), Sonenshein and Koszalka (1996), Merritt (1996b), Sonenshein (1997), and Langevin (2001). The position of the present-day saltwater interface (fig. 50) is a result of three principal mechanisms: (1) lateral landward movement of seawater in the surficial aquifer system from the Atlantic Ocean, (2) seepage from tidal canals containing saline water, and (3) upconing of relict seawater in response to well-field withdrawals.

In coastal areas under natural conditions, saltwater is present only near the shoreline and is balanced by a relatively higher onshore freshwater table having relatively high levels. Under equilibrium conditions, a slightly higher column of freshwater is necessary because freshwater is less dense than saltwater. Assuming static ground-water flow conditions of the Ghyben-Herzberg principle, there is approximately a $40-\mathrm{ft}$ column of freshwater below sea level for each foot of freshwater above sea level. The lowering of Everglades surface-water stage levels by gravity drainage in combination with intensive municipal withdrawals for water supply has helped to create an imbalance between freshwater and saltwater levels, contributing to the landward movement of saltwater.

Recognizing that the position of the saltwater front in the Biscayne aquifer during the 1950s was dynamically stable seaward of a position predicated by the Ghyben-Herzberg principle, Kohout (1964) concluded that dynamic equilibrium 


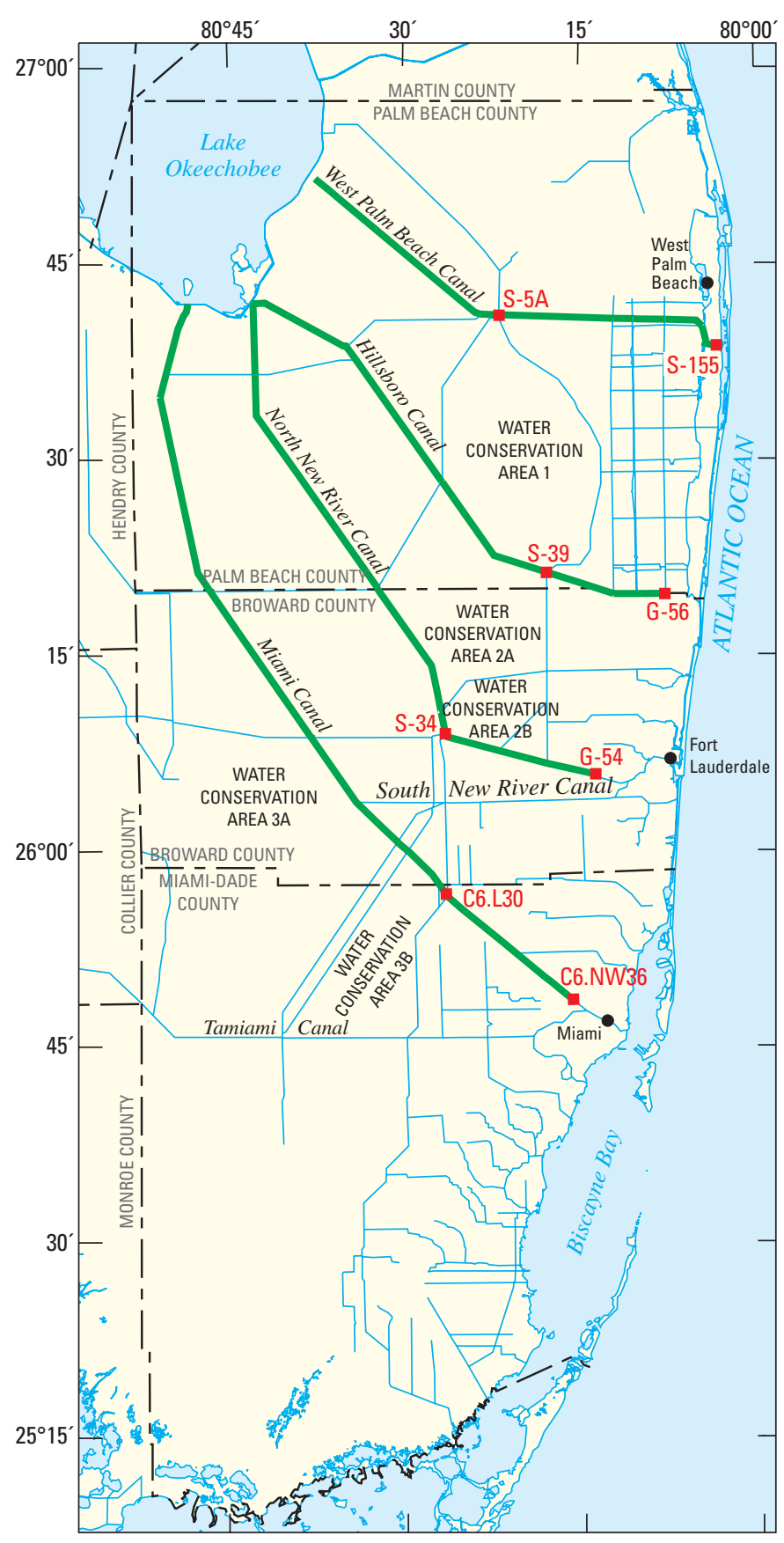

assumptions of static saltwater were incorrect. He determined that freshwater discharged coastward and upward beneath Biscayne Bay on the basis of fluid pressure and chloride concentration field observations, a mappable zone of diffusion, and flow net analyses. Saltwater flows back in a landward cycle from the seabed floor into the zone of diffusion, then upward and back to the sea floor (figs. 51 and 52). Tidal fluctuations, freshwater head change, and head loss within the landward cycle of saltwater movement help to minimize intrusion in a coastal aquifer (Cooper, 1959).

Saltwater encroachment in the surficial aquifer system in northern and central Miami-Dade County and southern Broward County (figs. 53-56) has been well documented by several researchers, including Parker and others (1955), Kohout (1960), Leach and Grantham (1966), Leach and others (1972), Hughes (1979), Merritt (1996b), and Sonenshein (1997). Uncontrolled drainage from the principal conveyance canals between 1904 and the early 1940s lowered ground-water levels nearly $6 \mathrm{ft}$ in the Everglades area, providing considerable opportunity for increased lateral intrusion into the surficial aquifer system (fig. 53). Large withdrawals from the Hialeah-Miami Springs Well Field (fig. 50) further contributed to canal seepage and the intrusion of tidal seawater into the Miami Canal. Seepage of saltwater from coastal tidal canals further contributed to saltwater intrusion problems.

During the 1940s, saltwater intrusion was mitigated mostly through use of temporary sheet-pile dam control structures. Salinity control structures in Miami-Dade County were constructed by 1946 to prevent overdrainage and increase water levels in the coastal part of the surficial aquifer system, and also to allow the timely release of water during floods. Ultimately, these measures helped reverse saltwater intrusion in central Miami-Dade County. The construction of surface-water control structures and improved water-management practices have considerably reduced the area of saltwater contamination from its maximum extent during the 1950s and early $1960 \mathrm{~s}$ (fig. 54). During the 1970s, Tamiami Canal salinity coastal structures were replaced with a new structure located 3 mi downstream, further reducing the intrusion of tidal canal water south and west of the Hialeah-Miami Springs Well Field (figs. 50 and 55) according to Klein and Ratzlaff (1989). During the 1980s and 1990s, chloride

Figure 47. Location of selected surface-water sites used to monitor canal stage and flow in southeastern Florida. 


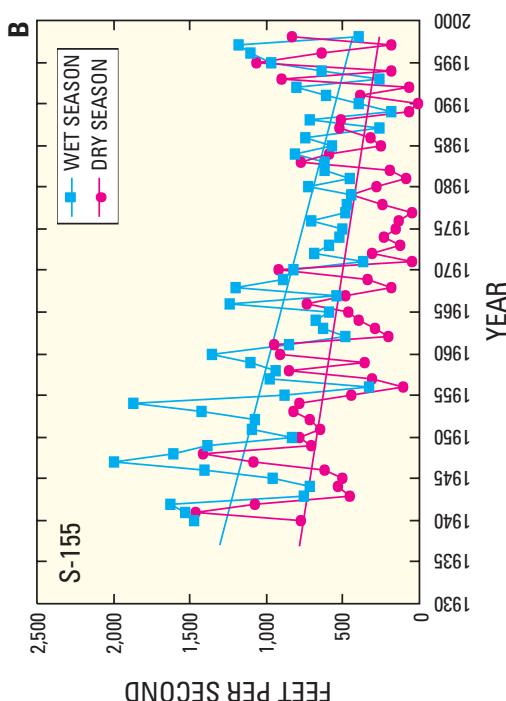

aNOJ $3 S$ Y $\exists d$ d 1 I $\exists$

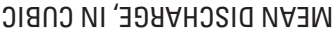

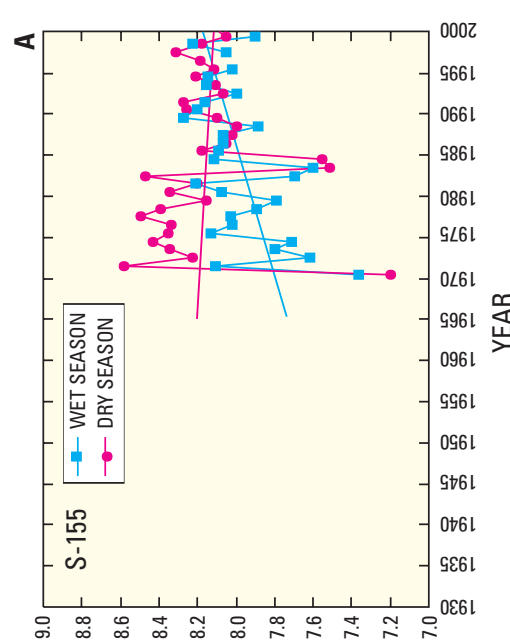

$1 \exists \exists \exists N I ' \exists 9 \forall I S N \forall \exists W$

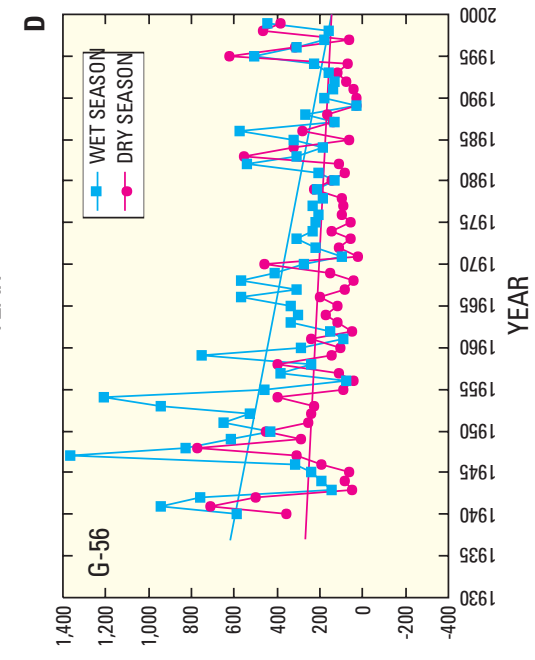

aNOJ S Y $\mathrm{Y}$ d $\perp \exists \exists \exists$

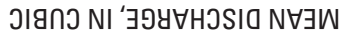

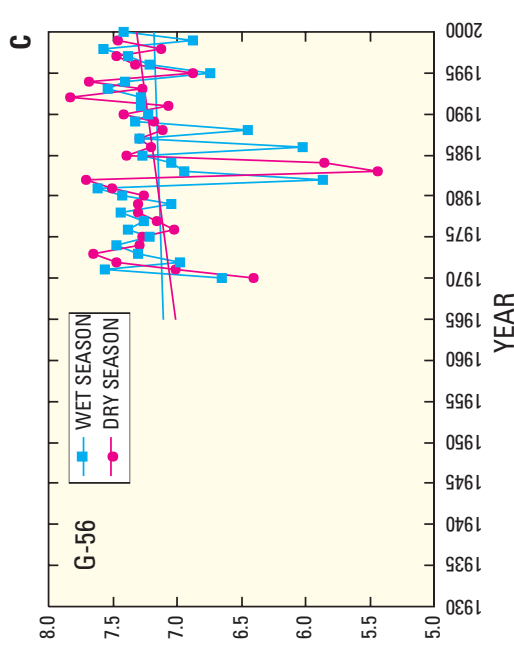

$1 \exists \exists \exists \mathrm{NI}{ }^{\prime} \exists 9 \forall I S N \forall \exists W$
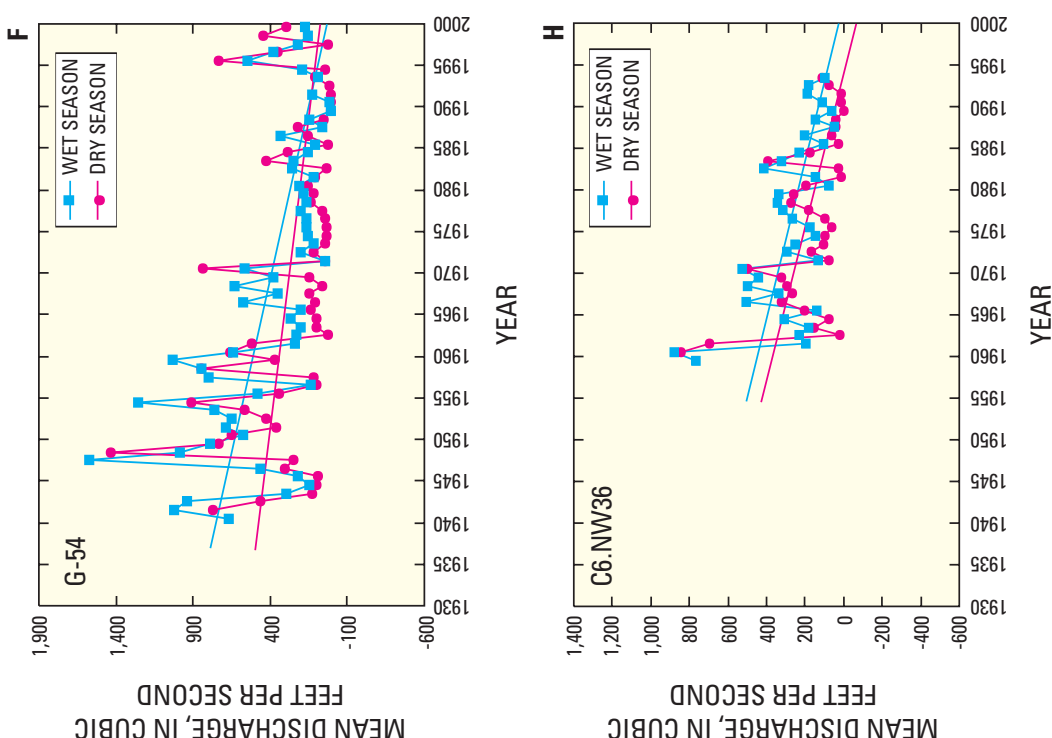

aNOJ $3 \mathrm{~S}$ Y $\exists \mathrm{d} \perp \exists \exists \mathrm{J}$

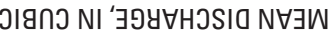

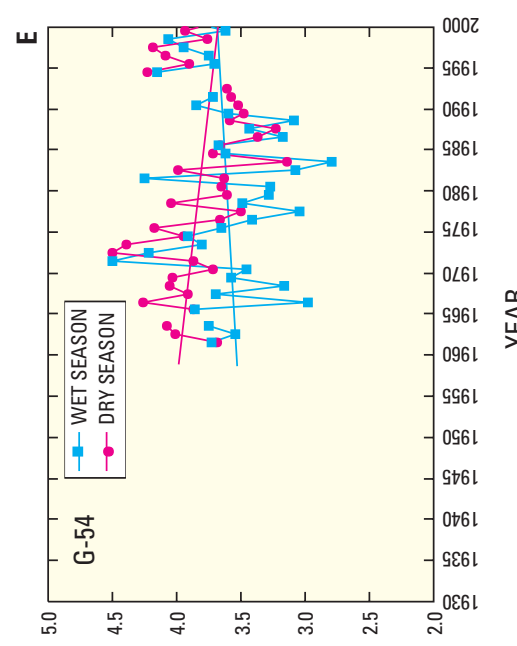

$\perp \exists \exists \exists N I{ }^{`} \exists 9 \forall \perp S N \forall \exists W$

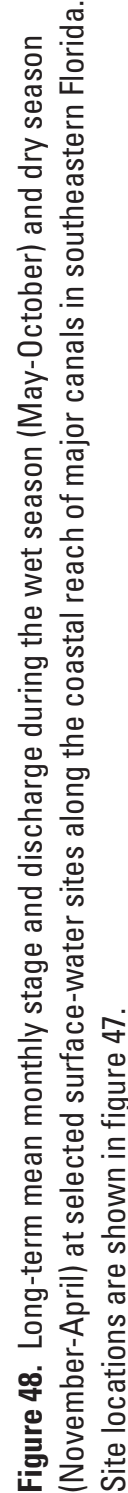




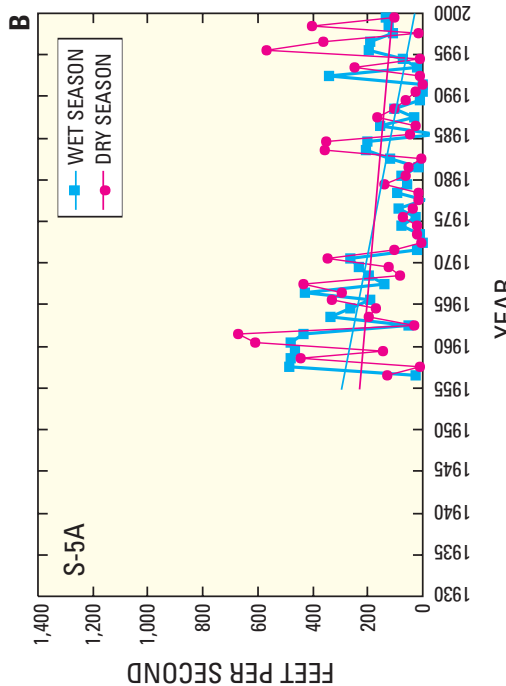

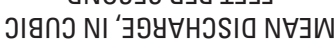

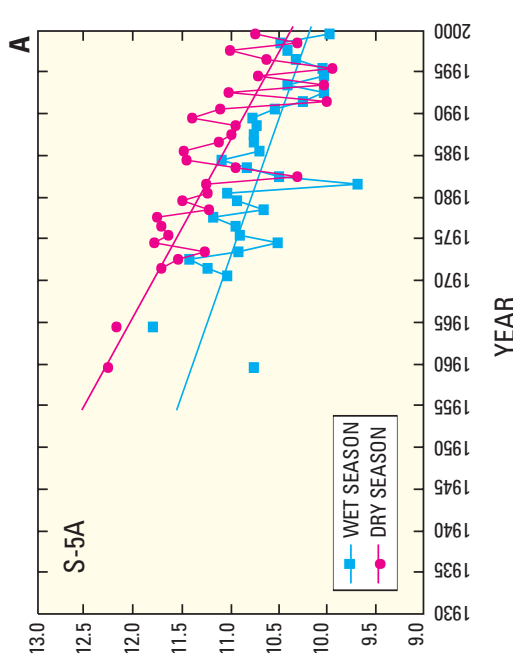

$1 \exists \exists \exists \mathrm{NI}{ }^{\prime} \exists 9 \forall I S N \forall \exists W$

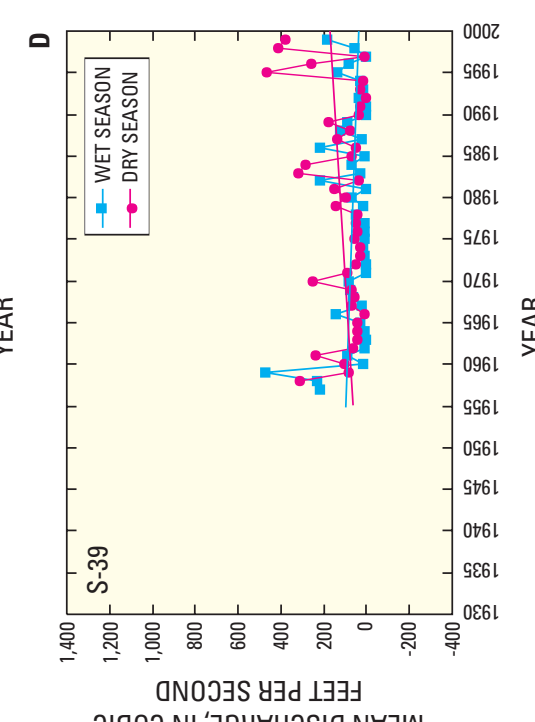

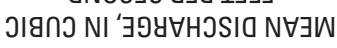

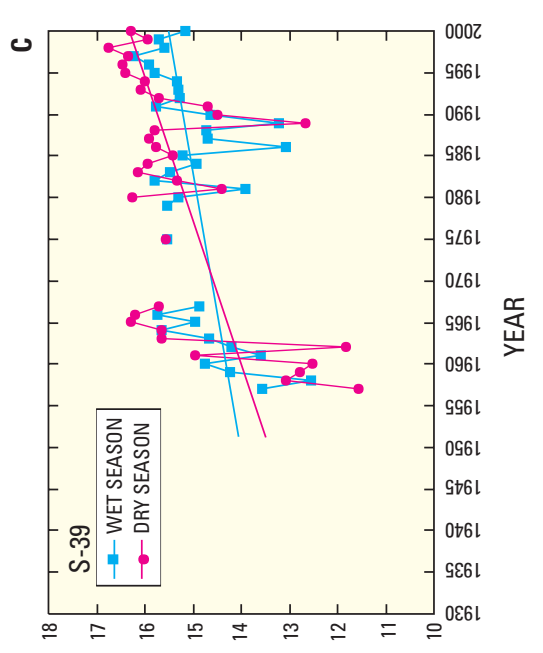

$\perp \exists \exists J \mathrm{NI} \exists \exists \forall 1 S \mathrm{~N} N \exists \exists \mathrm{W}$

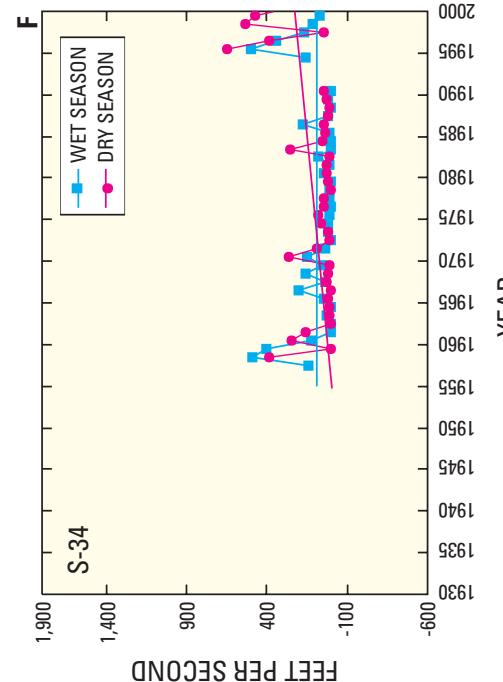

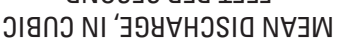

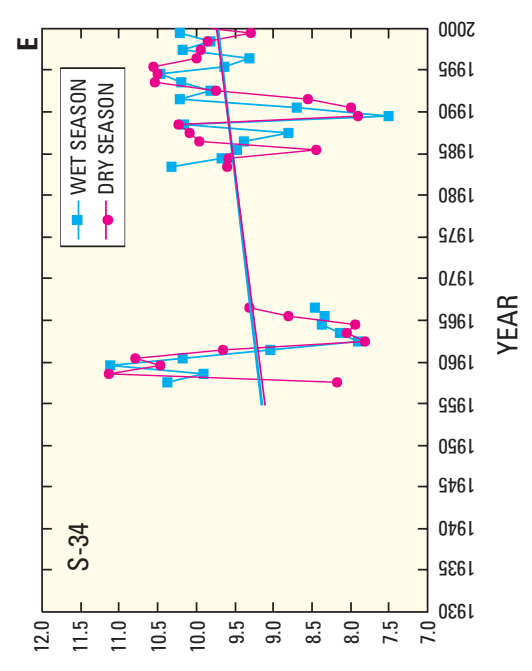

$\perp \exists \exists \exists \mathrm{NI} ' \exists 9 \forall I S N \forall \exists \exists$

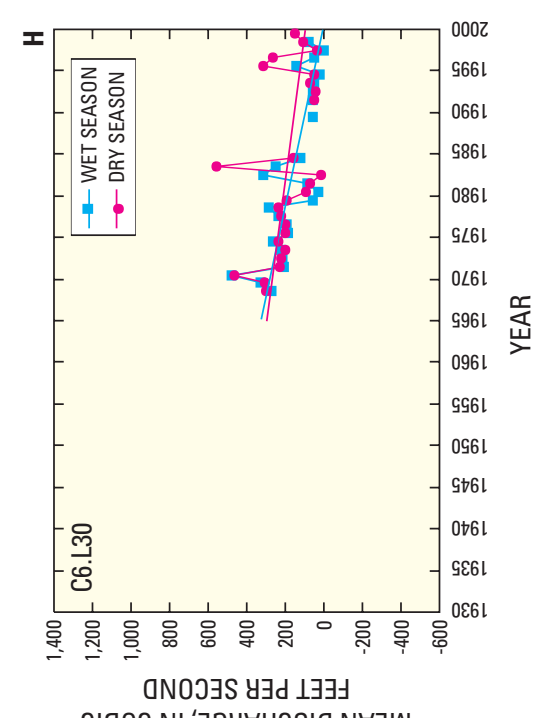

วเดกว NI'э9y

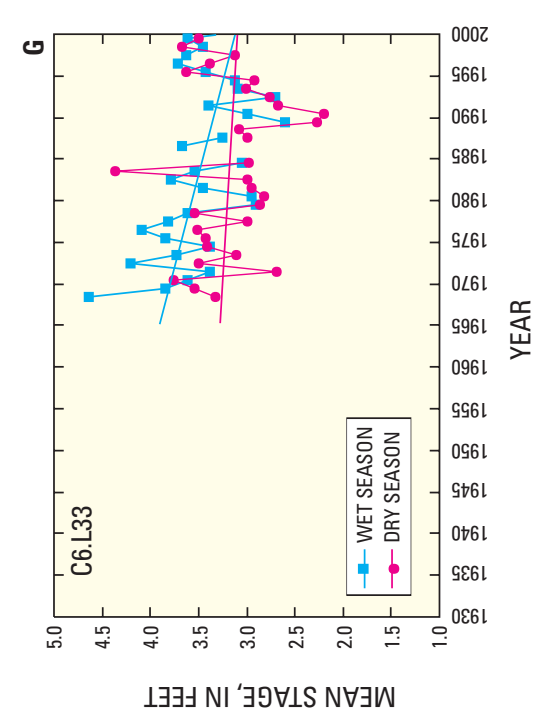

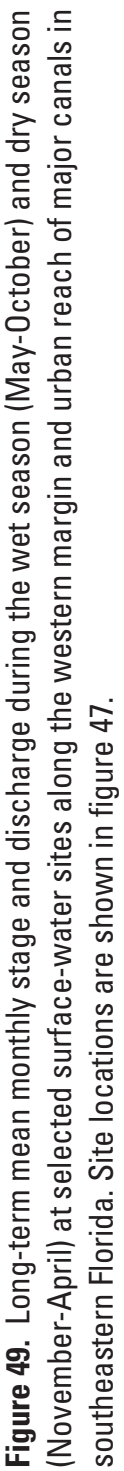




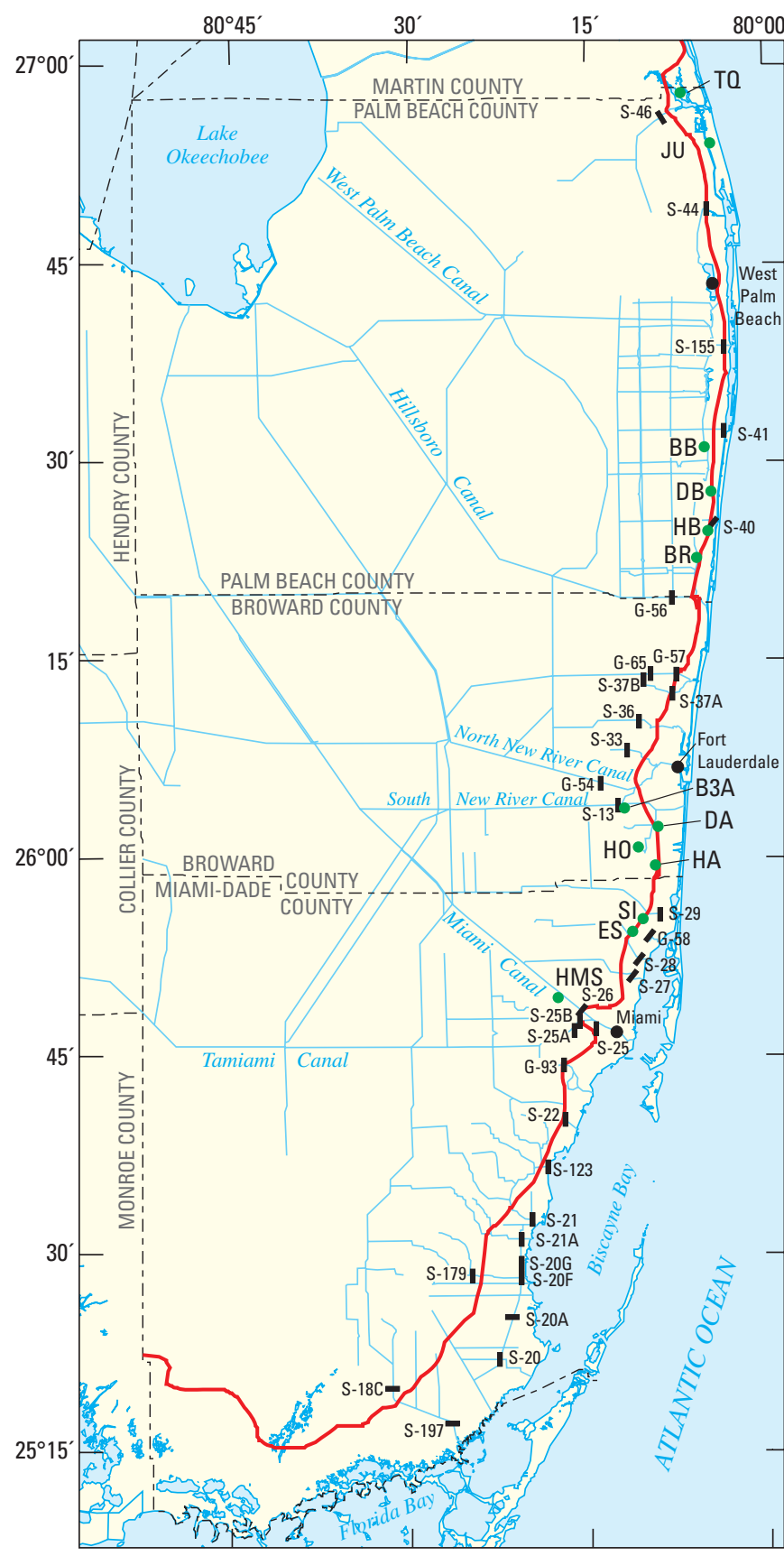

EXPLANATION

SALTWATER INTRUSION
LINE

S-29 I CONTROL STRUCTURE AND NUMBER

- WELL FIELD AND NAMES

BR Boca Raton

BB Boynton Beach

B3A Broward District 3A

DA Dania

DB Delray Beach

ES East Side

HA Hallandale

HMS Hialeah-Miami

Springs

HB Highland Beach

HO Hollywood

JU Jupiter

SI Sunny Isles

T0 Tequesta

\section{\begin{tabular}{llll}
0 & 5 & 10 & 15 \\
\hline
\end{tabular}}

$\begin{array}{llll}0 & 5 & 10 & 15 \text { KILOMETERS }\end{array}$ concentrations continued to decline as indicated in monitoring wells near the well field (fig. 55) because of a reduction in well withdrawals (table 1) as reported by Sonenshein and Koszalka (1996).

The temporal saltwater encroachment near Miami Canal, Miami-Dade County, has been well illustrated (figs. 53-55). Sparse well data having a suitable chloride sampling period and wide distribution, however, limit preparation of a similar temporal map series over a larger, multicounty area. Minor divergence between the mapped position of the 1984 interface (Klein and Waller, 1985) and the 1995 interface (Sonenshein, 1997) is attributable to interpretive differences resulting from limited well control data and not caused by a change in long-term hydrologic conditions.

The saltwater interface extended no more than $1 \mathrm{mi}$ from the coastline in most of Broward County prior to 1948, with the greatest intrusion occurring along the North New River Canal (Vorhis, 1948). Movement of the interface in Broward County is partly attributed to Central and Southern Florida Flood Control Project drainage canal construction during the 1950s and 1960s. Enhanced drainage helped to lower the ground-water table, and convert marginal wetland areas to suitable land for development. The saltwater interface lies well inland along the North and South New River Canals in east-central Broward County (fig. 56) where control structures have been constructed several miles inland to provide access for boating.

Landward movement of the interface in southeastern Broward and northeastern Miami-Dade County is evident in figure 56 (Merritt, 1996b). Saltwater intrusion forced closure of the Sunny Isles and East Side Well Fields in 1972 and 1977 (Merritt, 1996b). Additionally, tidal canal seepage and coastal saltwater intrusion have increased chloride concentrations near the Dania Cutoff, South New River, and Hollywood Canals (Merritt, 1996b, p. 25), affecting supply wells at the Dania, Broward 3A, and Hollywood Well Fields.

Water managers in southeastern Broward County, cognizant of low topography and its effect on saltwater encroachment, have closely monitored wells located east of the Hallandale Well Field since 1970. The westward progression of the saltwater interface (fig. 57) seems to maintain a similar physical structure to the "diffuse" coastal transition zones mapped near Cutler Ridge and Silver Bluff in Miami-Dade County (figs. 51 and 52). At the Hallandale Well Field (fig. 57), the 1,000-mg/L chloride concentration line is nearly horizontal at depths of about 75 and $160 \mathrm{ft}$ below land surface but vertical at greater depths, indicating vertical and horizontal concentration

Figure 50. Line depicting the landward limit of the saltwater interface in southeastern Florida in 1996.

Modified from Koszalka (1995), Merritt (1996b), Sonenshein (1997), Fitterman and Deszcz-Pan (1999), and Hittle (1999). 
A

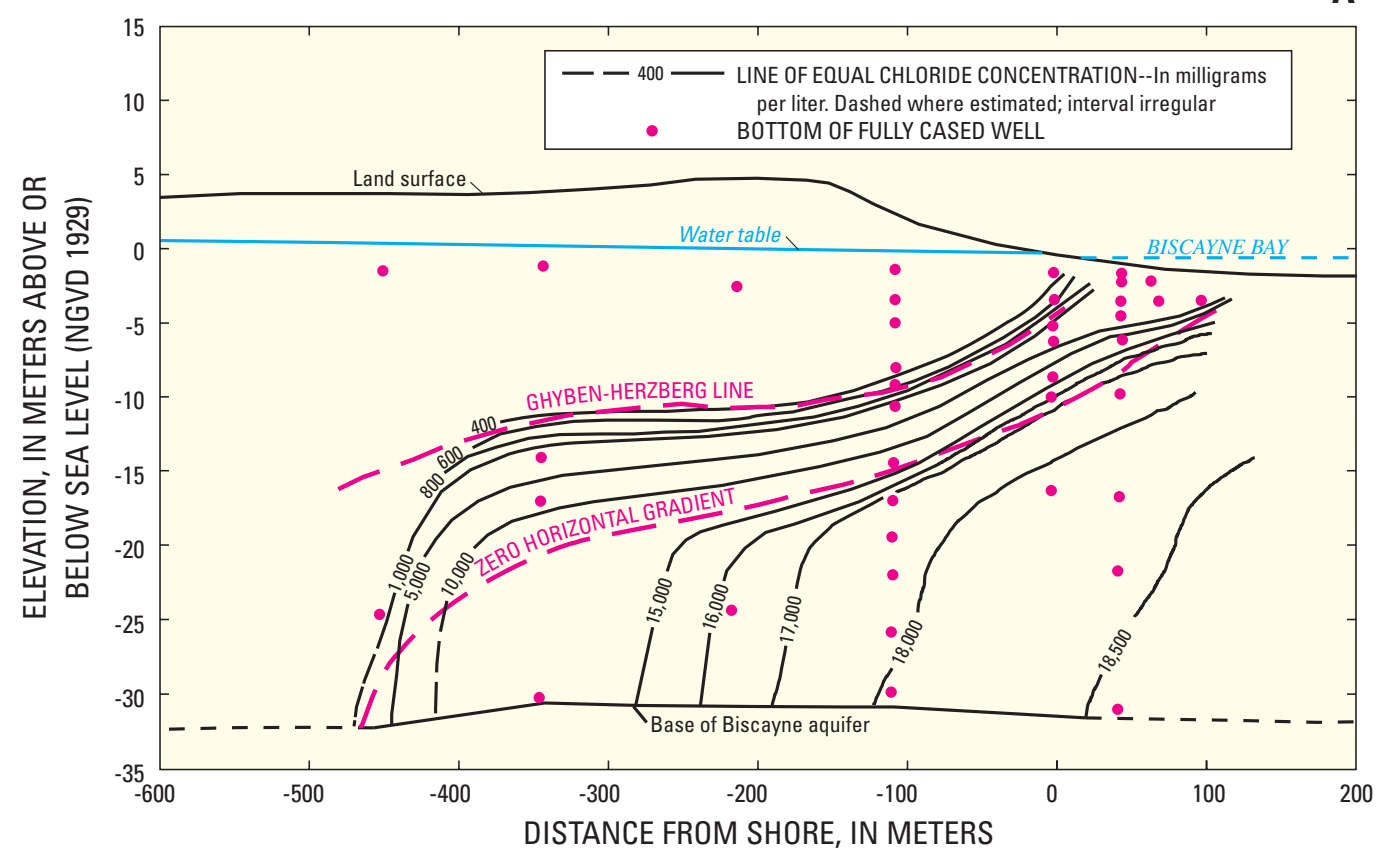

B

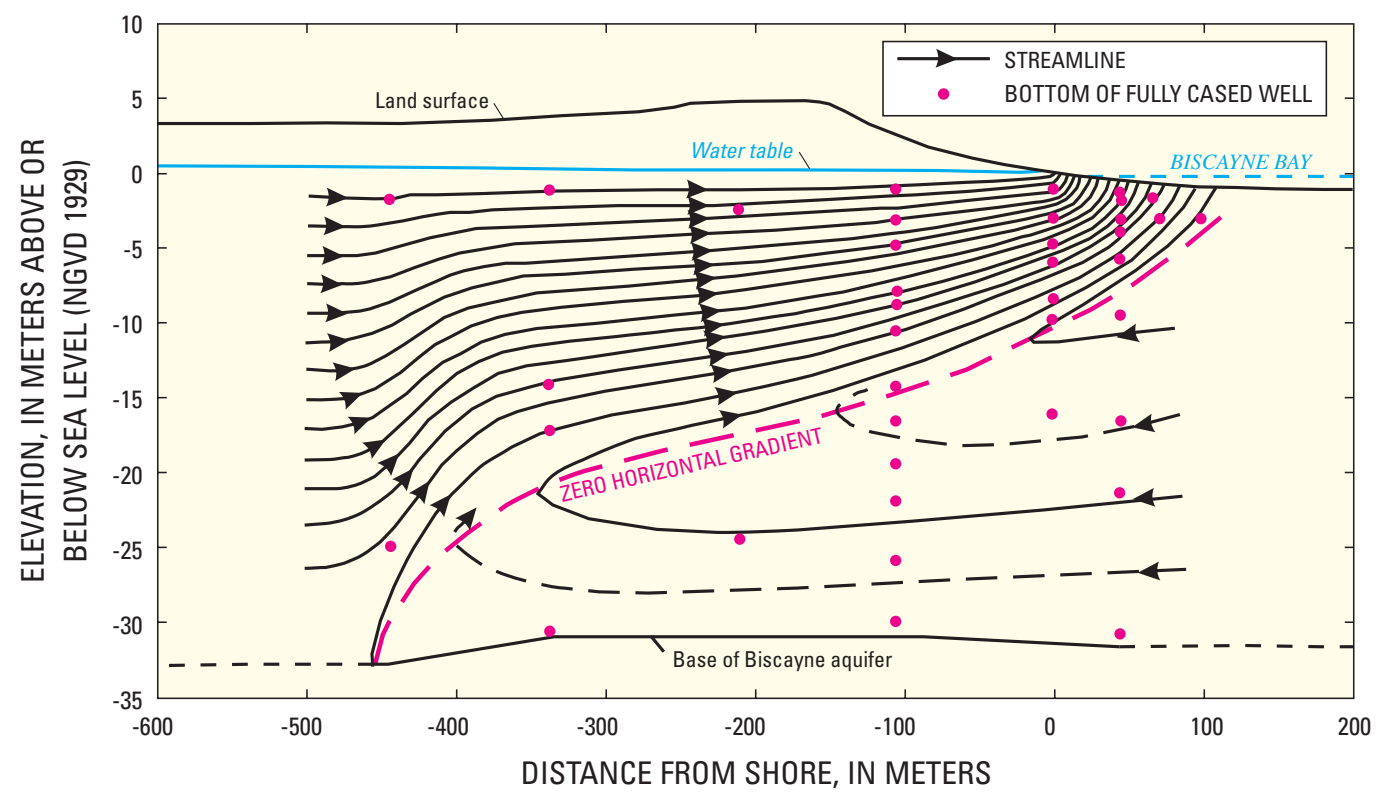

gradients, respectively. Merritt (1989) suggested that these chloride concentration gradients are indicative of preferential high-permeability flow zones.

Coastal well field withdrawals, elevated ground-water levels, and the effect of the canal drainage system are principal factors influencing the movement of the saltwater interface in Palm Beach County. For example, the LWDD maintains ground-water levels as high as $15 \mathrm{ft}$ above NGVD 1929 using a system of pumps, control structures, and equalizing canals (fig. 50). Accordingly, the influence of saltwater intrusion is substantially less in this area; however, saltwater intrusion has occurred in other areas of Palm Beach County near coastal well fields (fig. 50). The interface is reported to underlie the Highland Beach, Delray Beach, and Boynton Beach Well Fields and the coastal well fields of Boca Raton (Hittle, 1999). In response to increased salinity in coastal wells, the City of Boca Raton reduced withdrawals in those wells and has increased production from supply wells in the inland well fields. Saltwater intrusion also has been reported near the Tequesta Well Field in northeastern Palm Beach County (Scott and others, 1977), where the position of the interface probably reflects the effect of Loxahatchee River drainage lowering water levels in the aquifer (Hittle, 1999).

\section{Changes in the Marine Ecosystem of Biscayne Bay}

Shallow-water marine organisms are very sensitive to environmental changes in salinity, temperature, nutrient input, and dissolved oxygen. Temporal and spatial salinity patterns in Biscayne Bay have profoundly affected the marine ecosystem caused by water-management driven changes in surface- and ground-water discharge. In addition to those changes caused by natural events, long-term change in land and water uses during the $20^{\text {th }}$ century in the bay watershed contributed greatly to the deterioration of marine conditions. Water quality has been greatly degraded by increased nutrient loads, trace metals, and other pollutants. Dredging and artificial channels that were cut within

Figure 51. Cross sections through the Cutler Ridge area showing $(A)$ lines of equal chloride concentration and $(B)$ the results from a flow-net analysis, September 18, 1958. From Kohout (1964). 


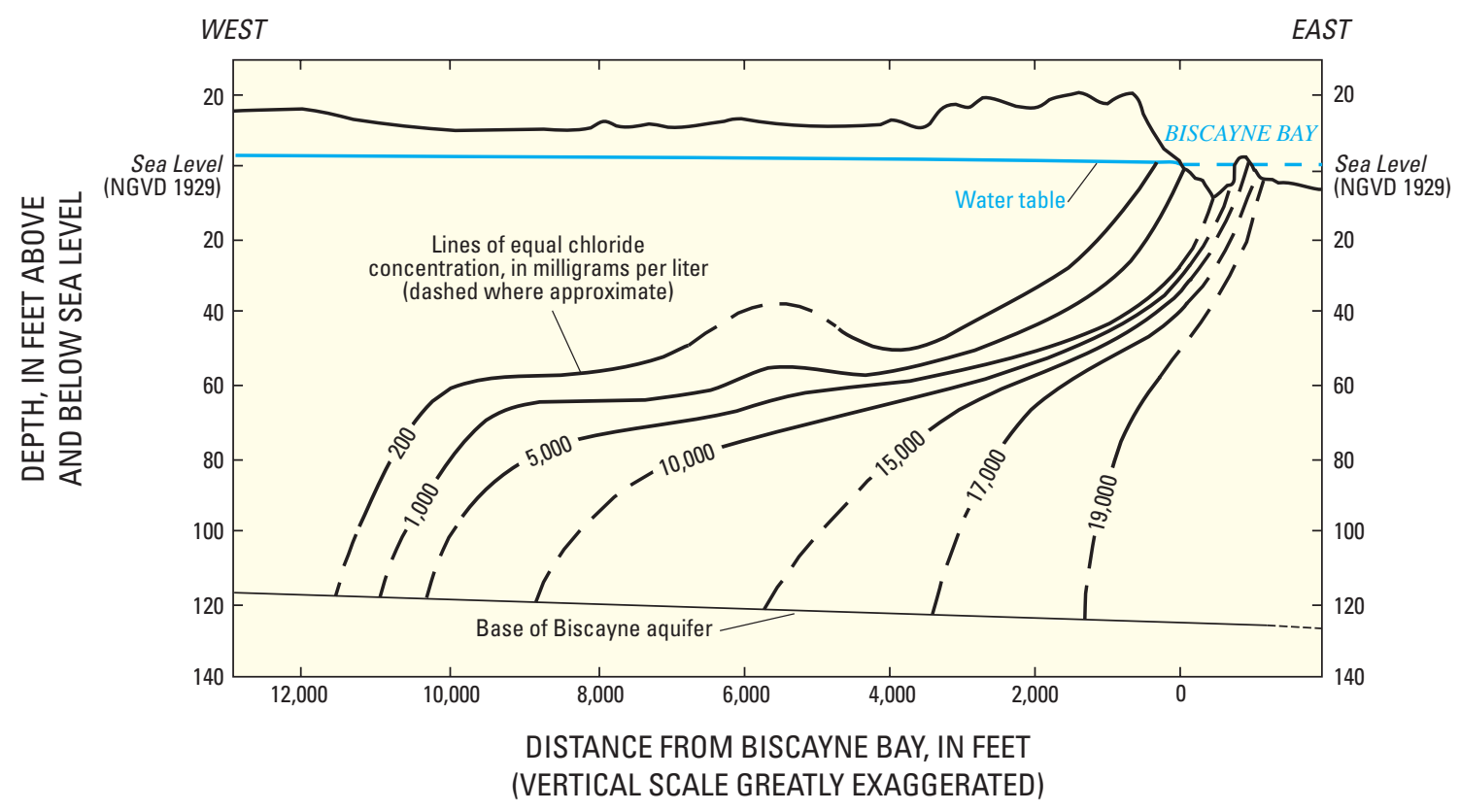

Figure 52. Cross section through the Silver Bluff area showing the zone of diffusion. From Kohout (1960).

the bay affected the water quality by removing natural seagrass beds and increasing turbidity (Wanless and others, 1984).

Although predevelopment spring discharge diminished considerably from pre-1907 flow conditions, Kohout and Kolipinski (1967) determined that the effect of coastal ground-water discharge on bay salinity was apparent in the broad zone of diffusion where chloride levels ranged from slightly saline $(400 \mathrm{mg} / \mathrm{L})$ near the shoreline to concentrations that were equivalent to native seawater farther offshore. According to Kohout and Kolipinski (1967), the upward movement of ground water in the littoral zone was manifest as salinity-controlled biological zonation of fauna and flora (fig. 58). On a more localized scale, Kohout and Kolipinski (1967, p. 491) observed that brackish, shallow water, nearshore spring discharge in Biscayne Bay was characterized by subcircular "ponds," formed by the restricted growth of seagrass sensitive to changes in salinity.

Sediment core profiling in 150 years of deposition in Biscayne Bay has revealed distinct changes in the marine ecosystem, which was different in the early to mid1850s than today. The salinity of bay coastal areas was much lower than the normal marine salinities of modern times (fig. 59). The water in Manatee Bay at the extreme southern end of Biscayne Bay was very nearly fresh. The central bay also was lower in salinity, but cores indicate lower magnitudes of change from normal marine salinity. Faunal evidence indicates possible lowered oxygen or higher organic concentrations in the surficial sediments by the late 1800s, which may have had a substantial effect on the abundance or density of seagrass present during that time. 

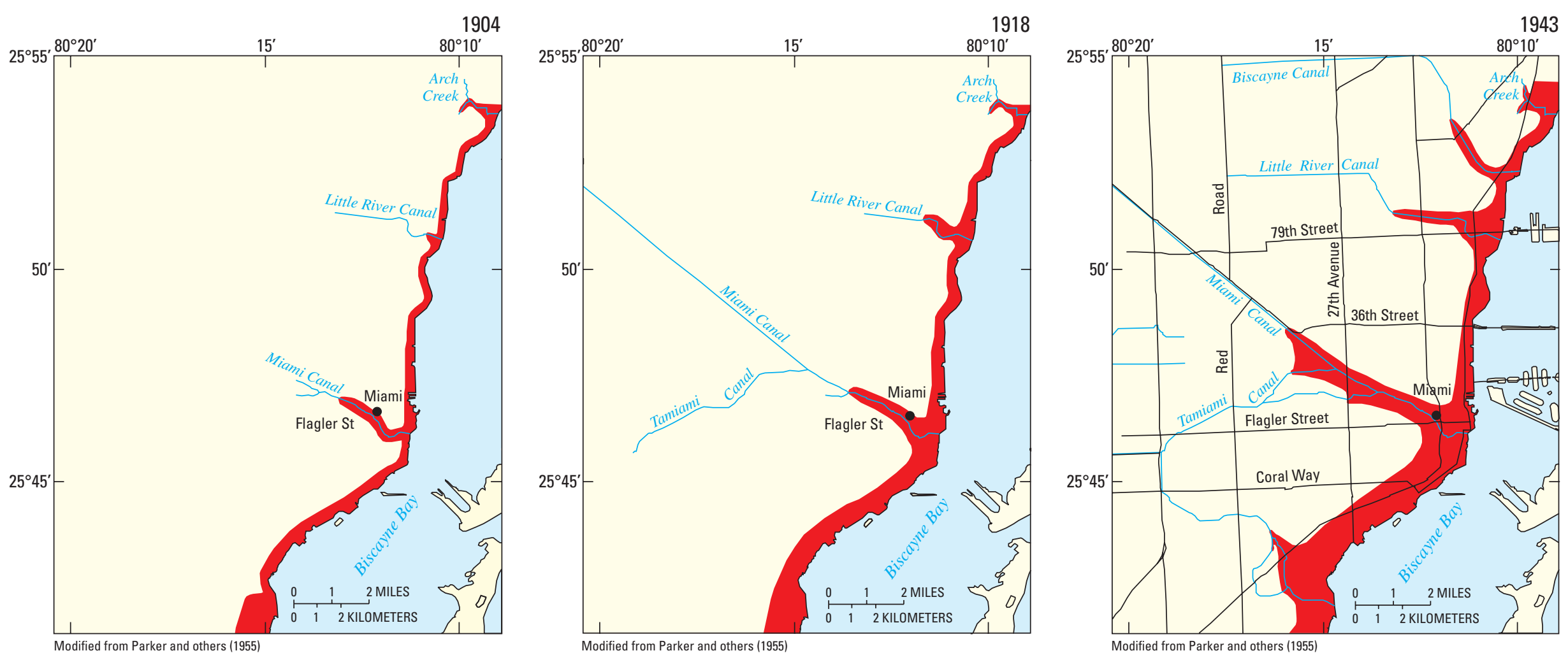

Figure 53. Saltwater intrusion (shown in red) near the Miami Canal in Miami-Dade County, 1904-43. 

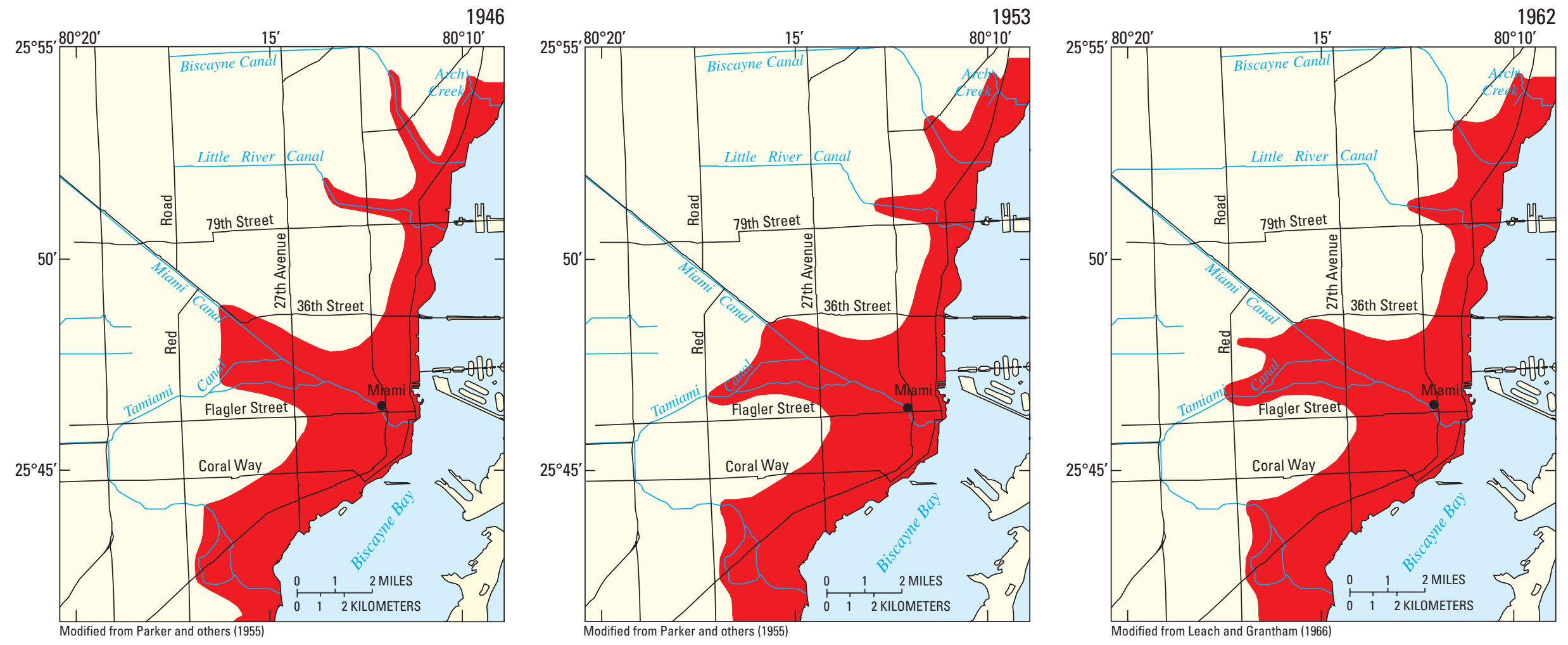

Figure 54. Saltwater intrusion (shown in red) near the Miami Canal in Miami-Dade County, 1946-62. 

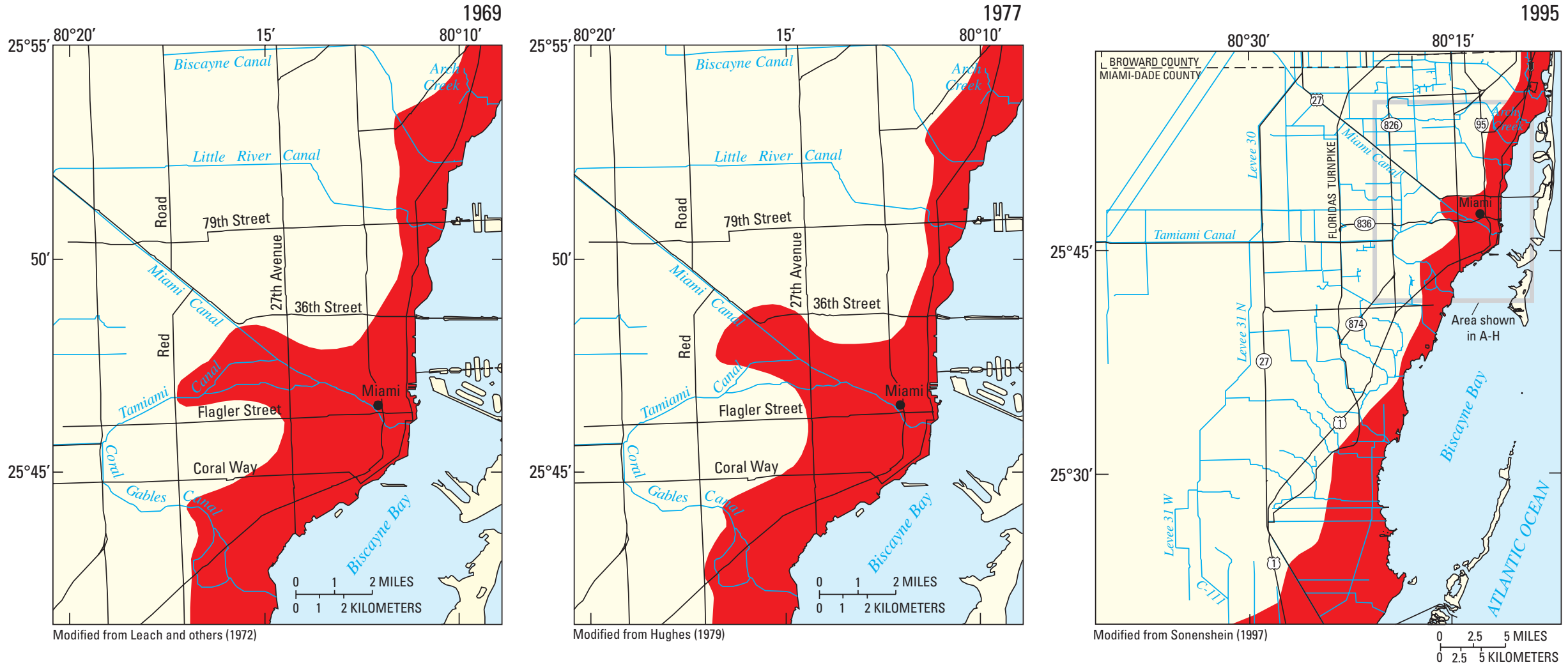

Figure 55. Saltwater intrusion (shown in red) near the Miami Canal in Miami-Dade County, 1969-95. 


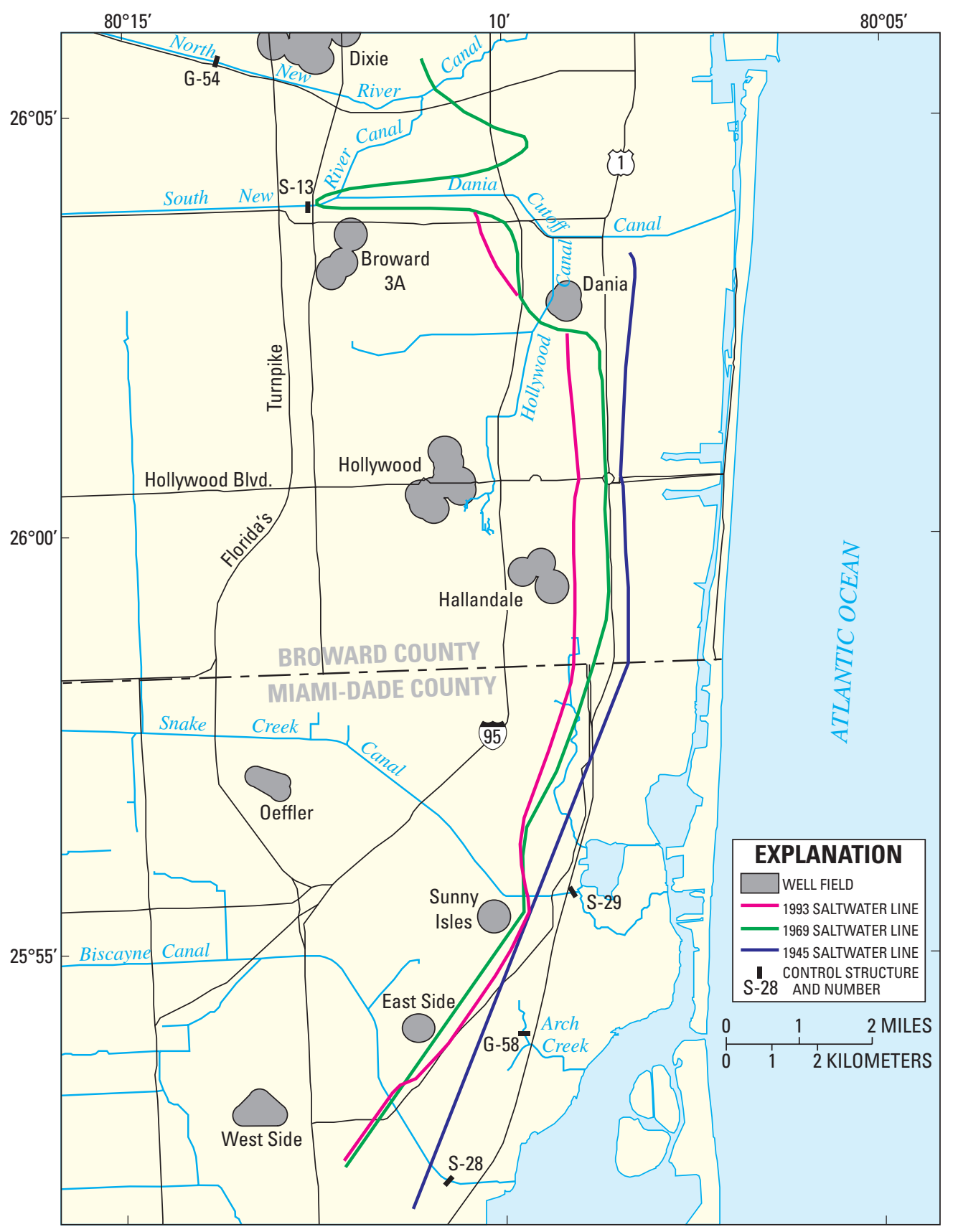

Sediment from the early 1900 s reflect the first marked change in salinity, which reached levels close to normal seawater. This increase is reflected by a substantial increase in the abundance of typical Atlantic Continental Shelf faunal components. Fossil evidence indicates that seagrass became more abundant from the early 1900s to present in the central bay (fig. 60). A similar record of ecosystem change is recorded in Manatee Bay (fig. 59), with a substantial change in salinity to mesohaline (5 to $18 \mathrm{ppt}$ ) conditions occurring in the early 1900s (Ishman and others, 1998). Coastal vegetation changes during this time, such as the first appearance of red mangrove in this region, are consistent with marine records and indicate increased salinity (Ishman and others, 1998).

Biscayne Bay salinity remained relatively stable until the early 1940s when it increased from about 18 to $40 \mathrm{ppt}$ on average, but was probably subject to broad fluctuations. The occurrence and increasing abundance of epiphytal and macroalgal habitat dwelling organisms indicate a change in substrate conditions and increased seagrass abundance during this time (Ishman and others, 1998). These latter changes appear to coincide with the construction of an enhanced canal, levee, and water-conservation area system designed to better manage water resources in the urban corridor and the Everglades. From the late 1980s to present, salinity decreased slightly in Manatee Bay, and field observations in this region suggest deteriorating conditions in the health of the seagrass (Ishman and others, 1998).

The freshwater-saltwater interface in southernmost Miami-Dade County is well inland of Florida Bay (fig. 50), according to Fitterman and Deszcz-Pan (1999), and ground-water discharge to overlying surface flows is considered to be relatively small compared to surfacewater outflows (U.S. Army Corps of Engineers and South Florida Water Management District, 1999). The lowering of the water table associated with the construction of an extensive drainage network helped to reduce surface flow in the lower part of the Everglades as experienced along the southeastern coast; such reductions in flow contributed to, and appeared to be closely timed with, the increase in salinity in Florida Bay (Halley and others, 1998).

Figure 56. Saltwater intrusion in southern Broward and northern Miami-Dade Counties in 1945, 1969, and 1993. Modified from Merritt (1996b). 


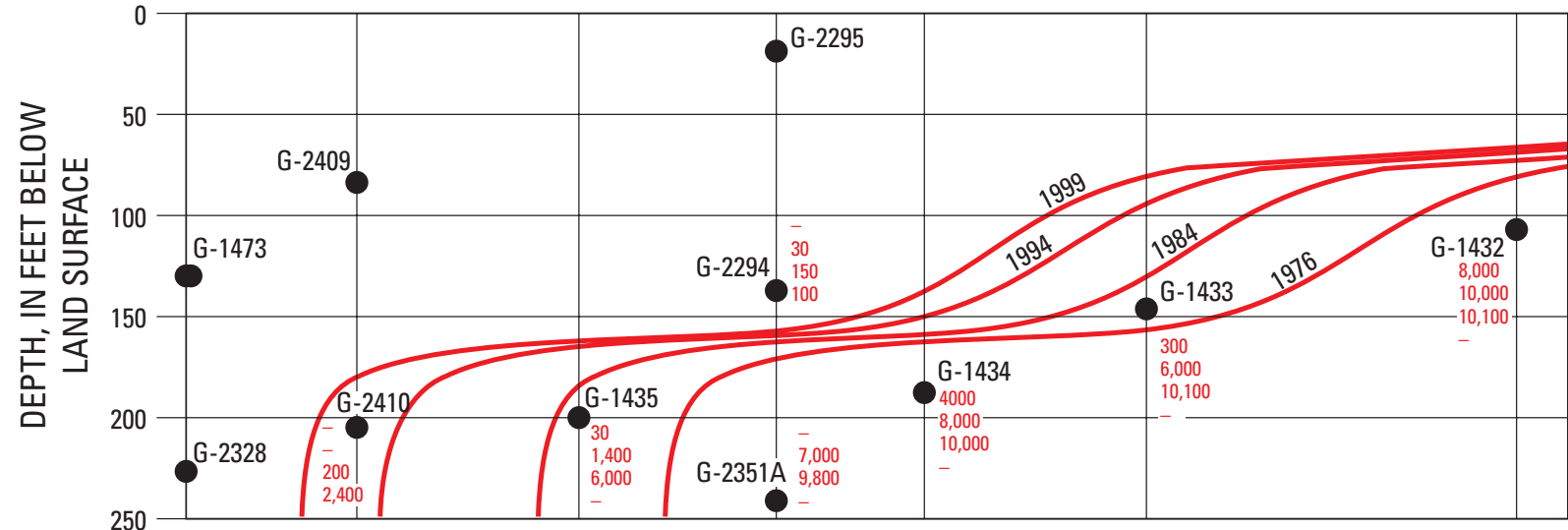

0.5 MILES
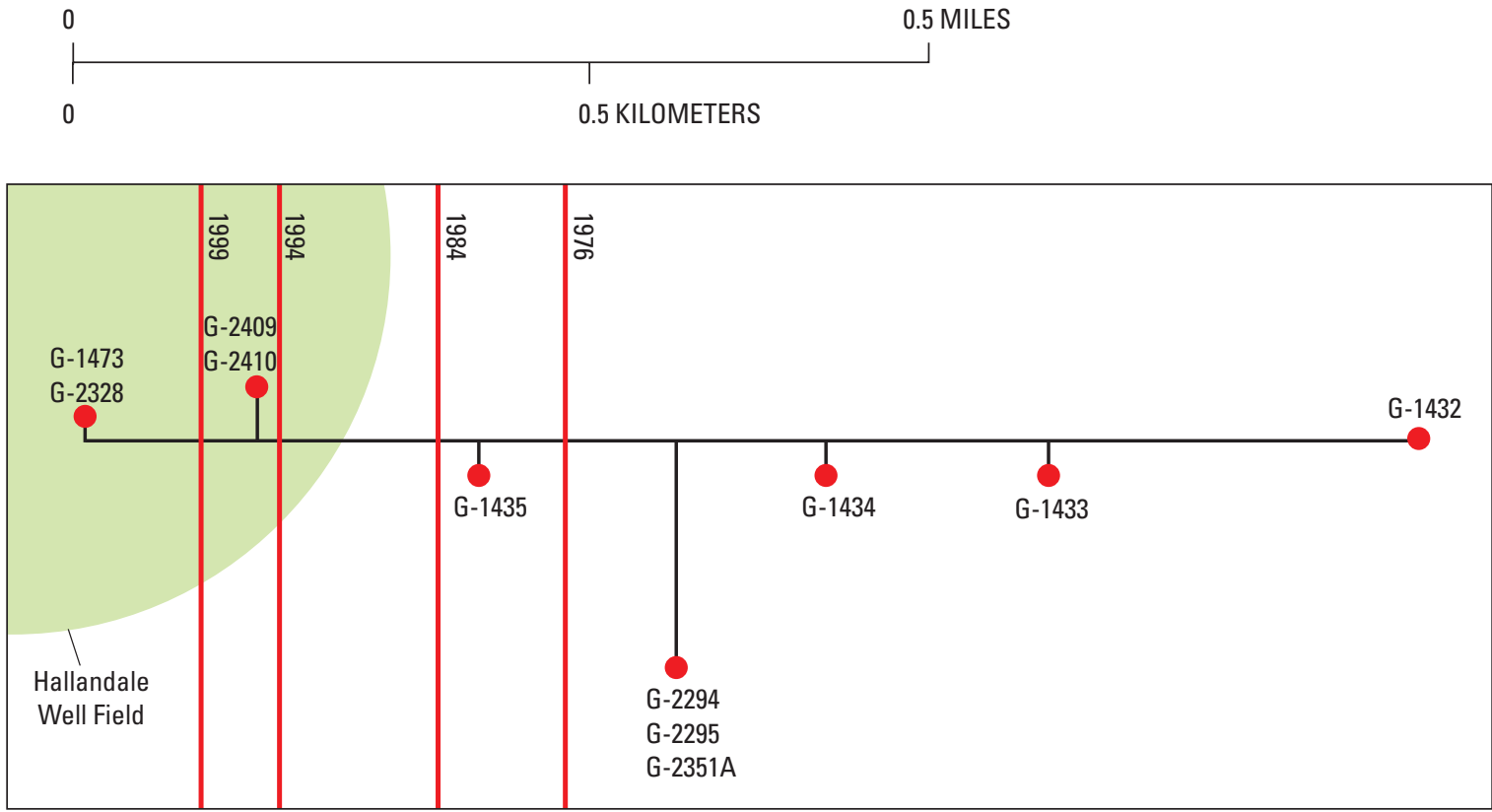

\section{EXPLANATION}

1,000 MILLIGRAMS PER LITER CHLORIDE CONCENTRATION LINE

WELL LOCATION AND NUMBER-Red

G-1432 numbers are chloride concentration, in 8,000 milligrams per liter for the indicated year 10,000
10,100 1976 $10,100 \backslash 1984$ 1999

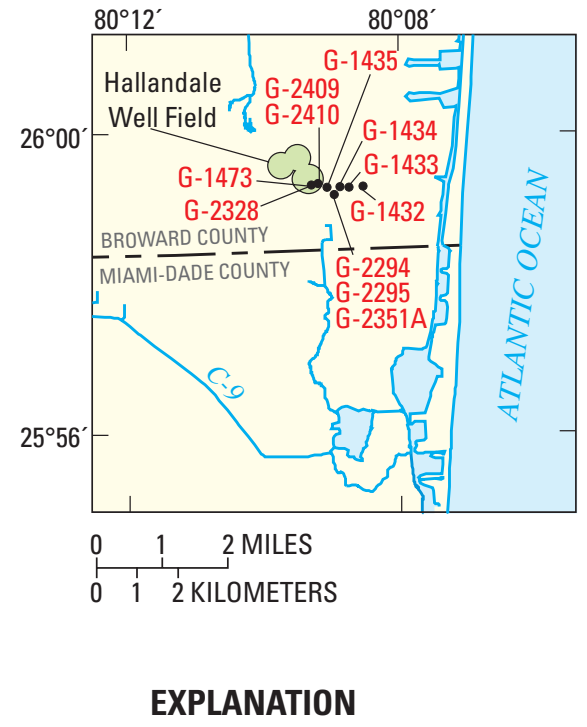

1,000 MILLIGRAMS PER LITER CHLORIDE CONCENTRATION LINE G-1433 WELL LOCATION AND NUMBER

Figure 57. Movement of the saltwater interface near the Hallandale Well Field in southern Broward County, 1976-1999. Derived from data and files of the U.S. Geological Survey. 


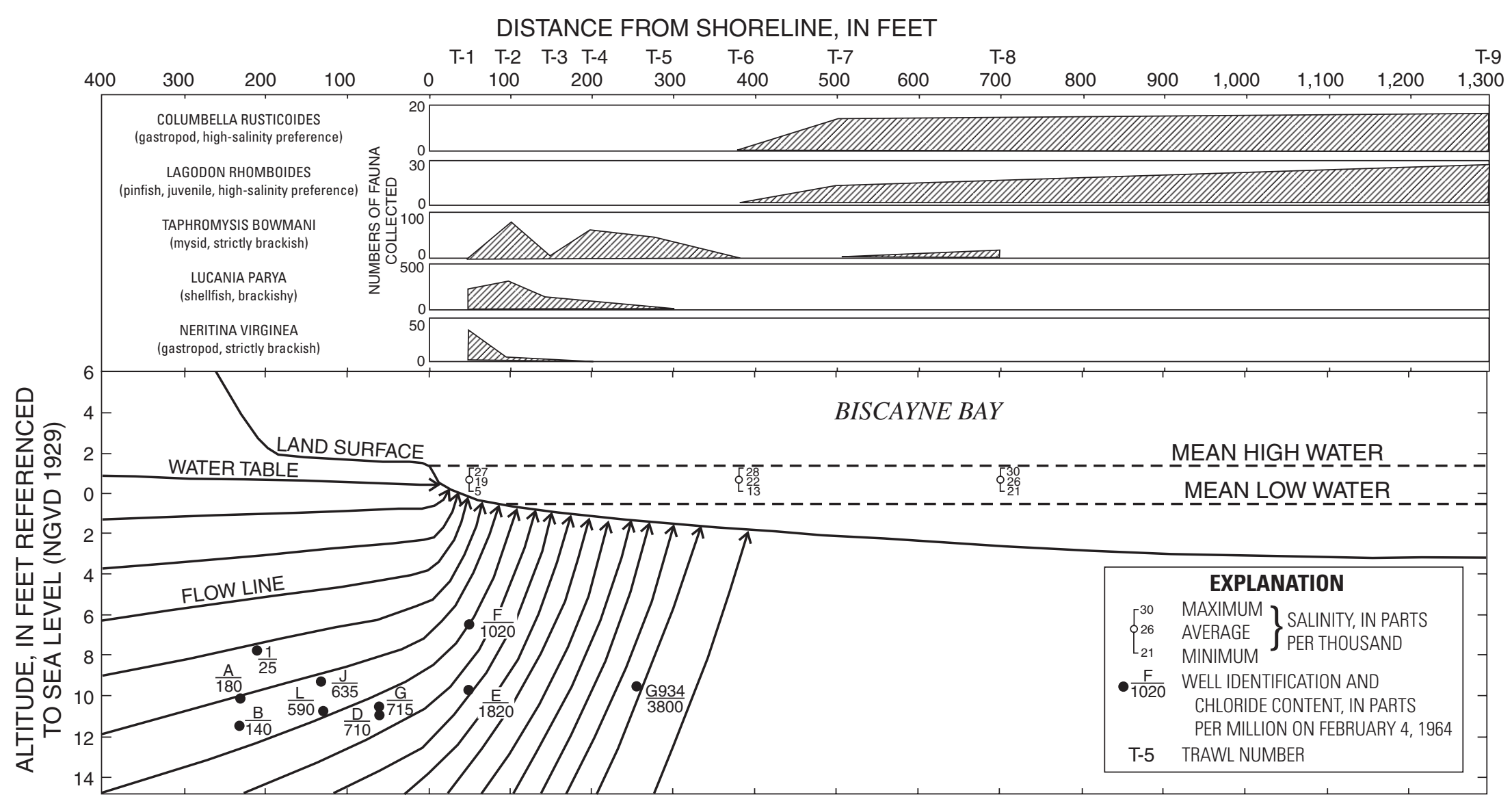

Figure 58. Distribution of selected fauna related to underlying hydrologic factors in the Cutler Ridge area. From Kohout and Kolipinski (1967). 


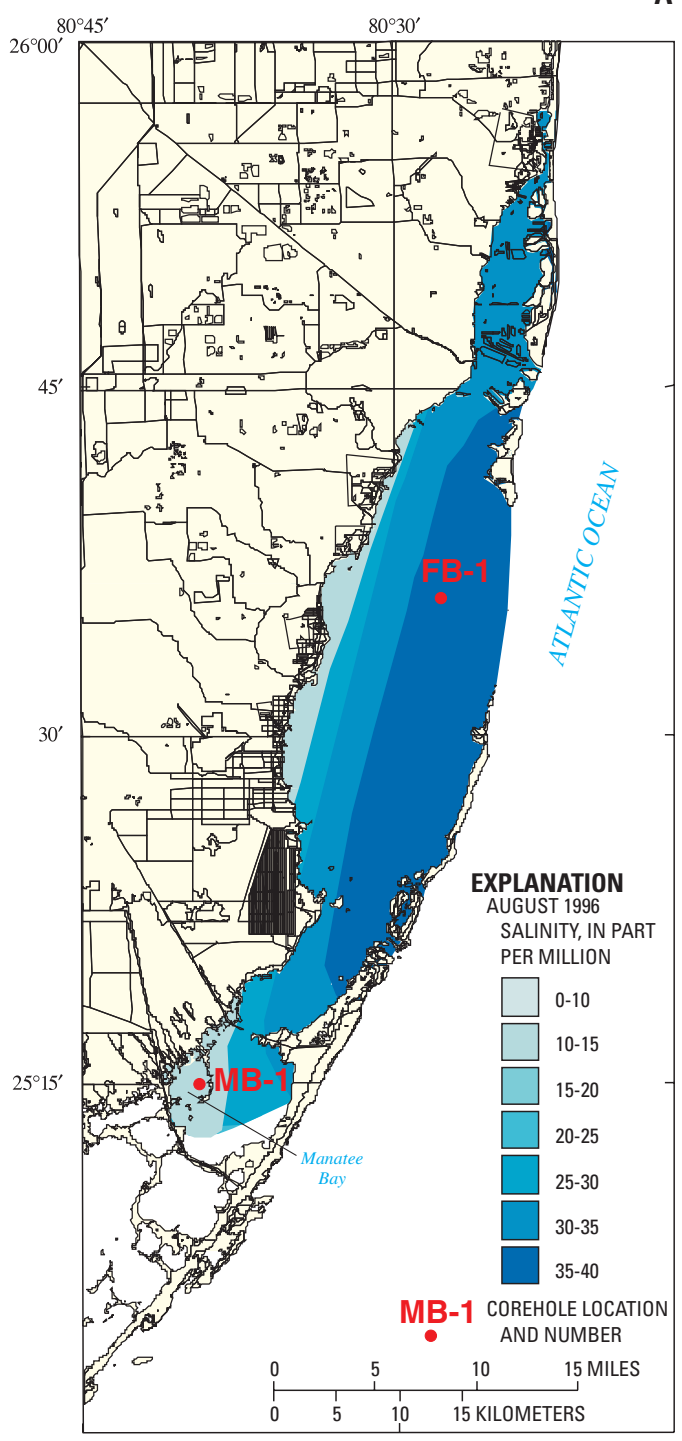

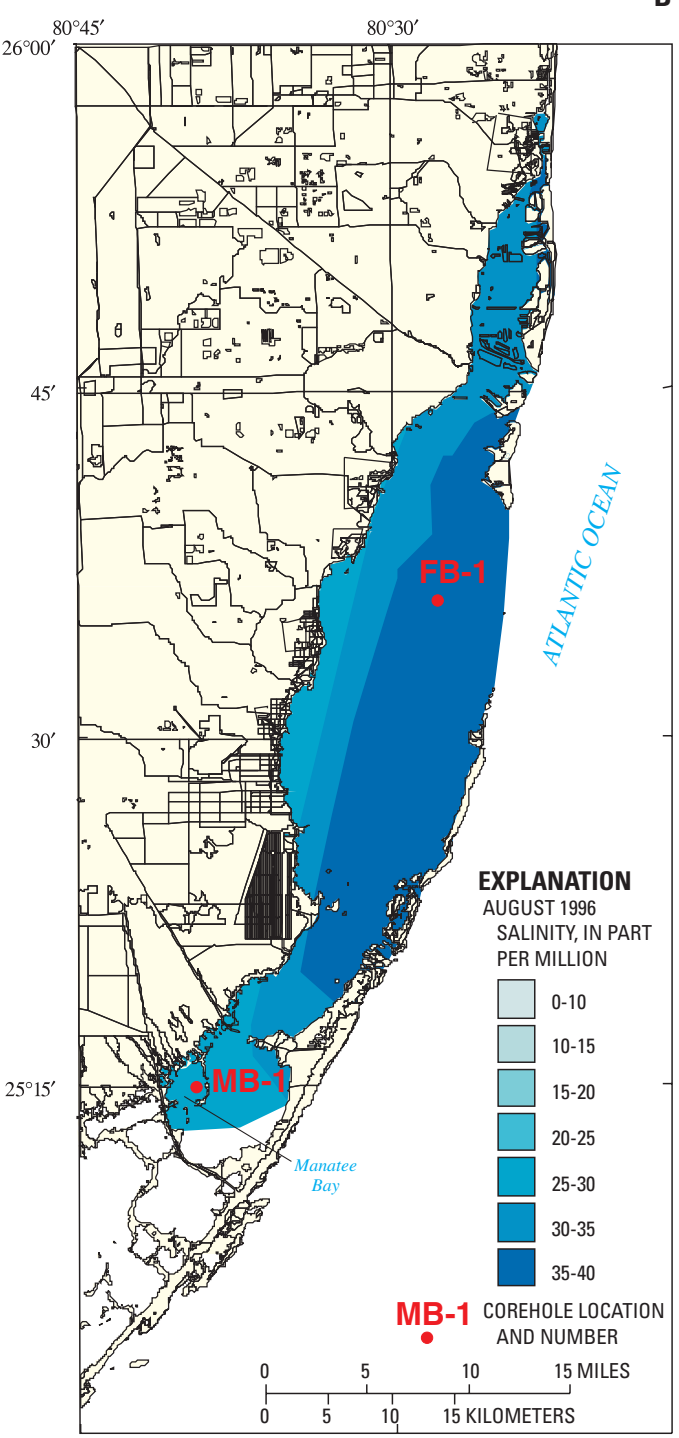

FB-1

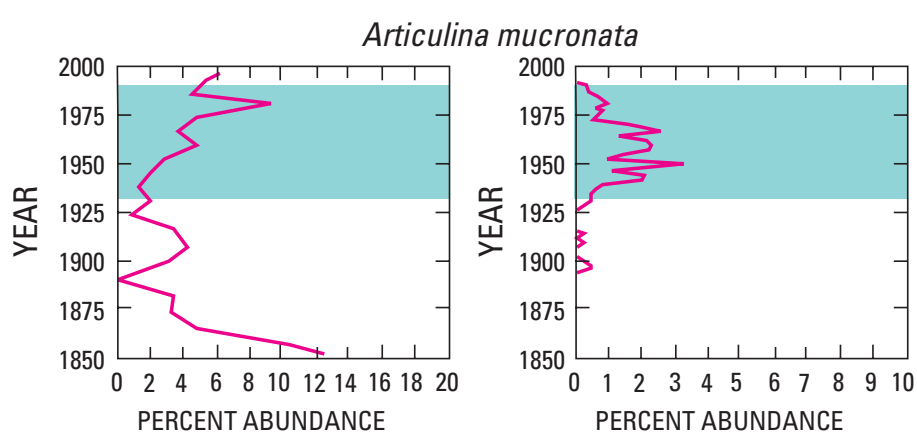

Archaias angulatus
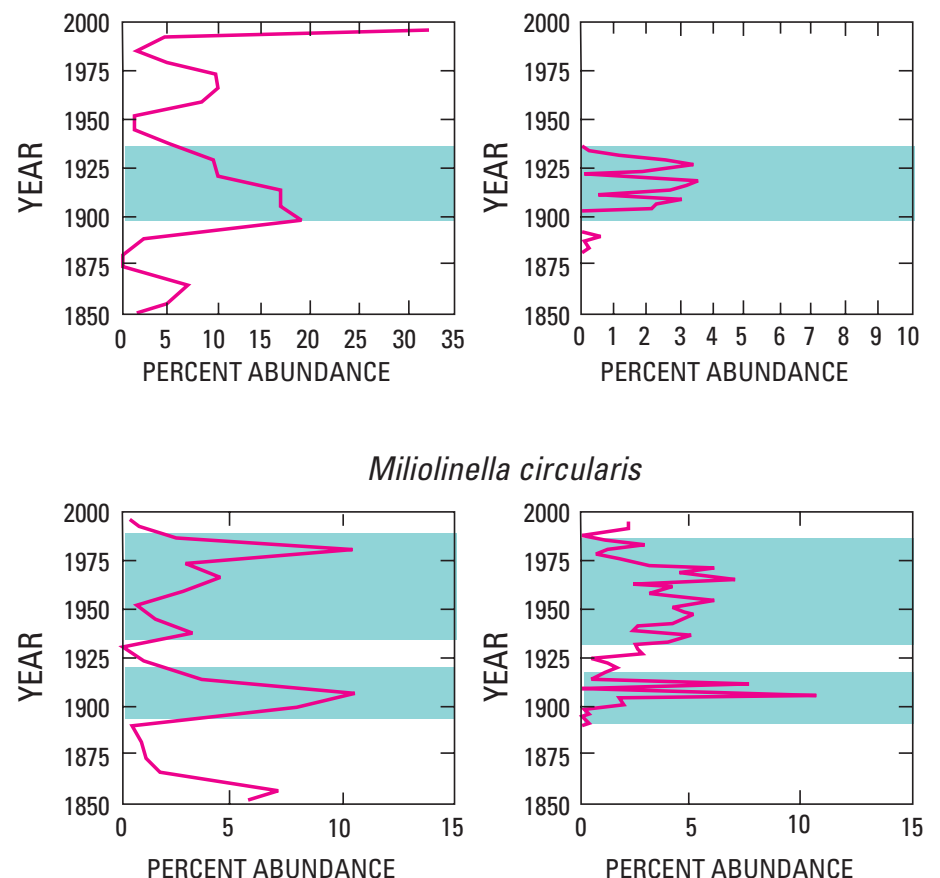

Figure 60. Relative abundance of three benthic foraminifera (Articulina mucronata, Archaias angulatus, and Miliolinella circularis) in cores FB1 and MB1 from Biscayne Bay. Significant shifts in their relative abundance in the cores are highlighted in blue to illustrate major changes in salinity and seagrass abundance/density from the late 1800s to present. Location of cores FB1 and MB1 are shown in figure 59. Modified from Ishman and others (1998). 


\section{Summary}

The urban and agricultural corridor of southern Florida lies between the Everglades and water-conservation areas to the west and the Atlantic Ocean to the east. The area, which includes eastern Miami-Dade, Broward, and Palm Beach Counties, has experienced explosive population growth (from less than 4,000 residents in 1900 to 5 million residents in 2000), and as such is subject to widely conflicting stresses on the environment. A highly controlled water-management system evolved during the $20^{\text {th }}$ century largely to provide drained land for a rapidly expanding population. Reclamation of Everglades wetland areas provided the opportunity for westward expansion of agricultural, mining, and urban activities. Surface water is impounded in water-conservation areas that lie west of the protective levee system, partly to: (1) sustain an Everglades ecosystem, (2) keep overland sheetflow from moving eastward and flooding urban and agricultural areas, and (3) use for water supply. Parallel environmental interests exist in coastal areas of the urbanagricultural corridor. Coastal residential and urban areas must be drained for flood control, whereas the underlying surficial aquifer system must simultaneously serve as the principal source for water supply, and ground-water heads must be maintained to prevent saltwater intrusion. Changes in predevelopment ground-water flow patterns and the associated reduction in ground-water discharge to coastal bays have altered salinity and affected the local ecology. Active since the early 1920s, extractive mining has increased considerably, largely to satisfy urban construction needs. The limited availability of limestone that meets construction requirements and simultaneous competition for land by both industries have placed both in direct conflict.

Surface- and ground-water systems were altered considerably by the construction of a complex system of canals and levees as well as by heavy municipa withdrawals. Between 1900 and 1948, uncontrolled canal drainage increased the rate of flow from the Everglades, reduced the extent of inundated land, and lowered ground-water levels. These canals failed, however, to transport the load imposed during flood events and worsened drought conditions through overdrainage of the surficial aquifer system. Drought and hurricane-related flooding provided the impetus for the 1949 establishment of the Central and Southern Florida Flood Control Project and District; canals were enlarged, conveyance structures and controls were installed, and protective levees were constructed. The southern Dade conveyance system was completed as the final phase of the project during the 1980s and involved redirecting surface-water flow and controlling ground-water levels in southeastern Miami-Dade County.

Ground water represents the principal source of water for municipal supply in the tri-county area of Miami-Dade, Broward, and Palm Beach Counties and has increased from three well fields producing about $66 \mathrm{Mgal} / \mathrm{d}$ in 1930 to about 65 well fields producing $770 \mathrm{Mgal} / \mathrm{d}$ in 1995 . West Palm Beach is the only large municipality that uses surface water for supply purposes. Miami-Dade County uses a centralized well-field infrastructure in which five large-capacity well fields withdraw the majority of the supply. A decentralized well-field infrastructure has been constructed in Broward and Palm Beach Counties, in which municipalities have relied on developing their own source of supply to meet local demand. On the basis of temporal analysis of well-field locations and production levels, there has been a historic shift from large well fields near the coast to more western facilities partly designed to mitigate saltwater intrusion.

Surface water is the primary source of water for cultivation of sugar, field, and row crops in much of Palm Beach County, particularly in the Everglades Agricultural Area; conversely Miami-Dade agricultural growers primarily rely on ground water withdrawn from shallow wells and conveyed using truck-mounted pump and spray irrigation systems. The agricultural industry of Broward County has been largely displaced by residential and urban development, despite once having been the Nation's primary winter producer of tomato, pepper, and bean crops, between the 1920s and 1940s. Broward County producers mostly relied on surface-water supplies until about 1960, when they converted to the use of ground water. Whereas agricultural activities in Broward County had become a minor factor in the county economy, cultivated lands expanded considerably in Miami-Dade and Palm Beach Counties between 1953 and 1988. Damage caused by Hurricane Andrew, which resulted in an agricultural financial loss exceeding $\$ 1$ billion, appears to have contributed to the decline in cultivated lands in Miami-Dade County since 1992. Agricultural water use in the tri-county area increased from $505 \mathrm{Mgal} / \mathrm{d}$ in 1953 to almost $1,150 \mathrm{Mgal} / \mathrm{d}$ in 1988, declining to $764 \mathrm{Mgal} / \mathrm{d}$ in 1995.

The surficial aquifer system, the principal source of ground water in southeastern Florida, is a wedge-shaped, eastward thickening sequence of limestone, quartz sand, shell, and terrigeneous mudstone of Pliocene to Holocene age. The prolific Biscayne aquifer, a sole-source aquifer, is the most transmissive of three separate aquifers that comprise the surficial aquifer system. Transmissivity of limestone-rich areas is greater than $1,600,000 \mathrm{ft}^{2} / \mathrm{d}$ but decreases to $54,000 \mathrm{ft}^{2} / \mathrm{d}$ where the surficial aquifer system mostly consists of sand; yields of 1,000 to $7,000 \mathrm{gal} / \mathrm{min}$ are reported from some wells completed in the cavernous part of the surficial aquifer system.

Well fields have been constructed farther inland during the latter part of the $20^{\text {th }}$ century because of coastal saltwater intrusion. Competition between agriculture, the Everglades ecosystem, and mining interests ultimately limits construction of new well fields along the western margin of the urban corridor. The underlying Floridan aquifer system is viewed as an alternative source of water for municipal supply either by treatment of saline water through reverse-osmosis processes, or by storage of 
freshwater by use of aquifer storage and recovery (ASR). A large network of ASR wells is being evaluated for Everglades restoration purposes if regional hydrologic and local geotechnical, hydraulic, and water-quality issues can be resolved. The lower part of the Floridan aquifer system is used for disposal of liquid waste by deep well injection for municipal industrial wastewater and reverse-osmosis concentrate. More than 20 Class I injection wells were operating in the tri-county area by 2000 , injecting treated wastewater into the Boulder Zone at depths of 2,000 to 3,000 ft below NGVD 1929. Deep well injection is under greater scrutiny in recent years largely because of a growing need to use the aquifer for purposes other than for waste disposal.

Few data are available to accurately document the predevelopment conditions within the surficial aquifer system; the water table probably subtly reflected the Atlantic Coastal Ridge topography. Peat and muck deposits, an important predevelopment component of Everglades surface- and ground-water hydrology, functioned as a storage reservoir to a water column that extended upward from the underlying aquifer and maintained a higher water table that prolonged the hydroperiod and restricted movement of a coastal saltwater interface. Surface-water stage within the adjoining Everglades was sufficient to allow water to discharge through traverse glades areas, and shoreline and submarine springs discharged freshwater. Uncontrolled canal drainage and a lengthy drought in 1945-46 caused water levels to reach their lowest recorded levels, exacerbating municipal well-field saltwater intrusion problems. The modern-day water table largely reflects the hydrologic influence of numerous engineering features, including primary and secondary canal systems, gated control structures, levees, impoundments, pump systems, and the drawdown effects of the larger well fields. Ground-water movement is largely coastward and water levels are highest near the water-conservation areas, except locally in southeastern Palm Beach County and northeastern Broward County, where surface water is pumped from the Hillsboro Canal into secondary canals to artificially maintain water levels. Regional water-level comparison maps of the difference in "average conditions" show that improved drainage systems built during the 1950s lowered inland ground-water levels and increased land areas for urban and agricultural development.

Gated coastal canal structures are used to retard landward movement of saline water during the dry season through maintenance of stage higher than local water levels, inducing seepage into the aquifer. Management of canal stage has helped to increase ground-water levels in some coastal areas. Long-term canal coastal discharge appears to have declined, but coastal canal stage has been maintained gradually at higher levels, presumably to impede saltwater intrusion. Diminished coastal discharge is attributed to the rerouting of surface water to secondary canals, and induced recharge to the aquifer caused by increased municipal withdrawals.
Calcium bicarbonate water is dominant in shallow parts of the surficial aquifer system, whereas sodium bicarbonate and sodium chloride water are dominant in more deeply buried parts of the aquifer system or along the coast. Chloride concentrations generally are less than $100 \mathrm{mg} / \mathrm{L}$ at depths shallower than $50 \mathrm{ft}$, except in coastal areas and southeast of Lake Okeechobee. Chloride concentrations are less than $100 \mathrm{mg} / \mathrm{L}$ at the 150-ft depth in eastern Palm Beach County, eastern Broward County, and much of central and northwestern Dade County.

A broad zone of diffusion characterizes the saltwater interface in southeastern Florida in which the position of the interface is a consequence of three principal mechanisms: westward lateral movement of seawater within the surficial aquifer system, seepage from tidal canals, and upconing of relict seawater. Prior to 1945 , uncontrolled drainage contributed considerably to lowering the water table of the surficial aquifer system along the Miami Canal. Water levels were lowered further by heavy municipal withdrawals, inducing tidal seepage into the aquifer system. Canal drainage contributed greatly to intrusion of the saltwater interface in Broward County, lowering ground-water levels with the subsequent landward movement of saltwater in the surficial aquifer system from the Atlantic Ocean. Well-field withdrawals and tidal seepage are an important, but less important, source of saltwater intrusion

Predevelopment freshwater spring discharge in Biscayne Bay diminished considerably following the emplacement of canal drainage networks and the loss and compaction of inland peat deposits that formerly maintained higher water levels in the ecosystem, and stored excess surface water that helped to recharge the underlying aquifer. Changes in land use and water-management practices have greatly impacted the marine ecosystem of Biscayne Bay, resulting in increased nutrient loads and other pollutants, and increased turbidity. Prior to construction of the major canals, the salinity of the southernmost part of Biscayne Bay was much lower than normal marine salinity, especially near the coastline from Manatee Bay to possibly as far north as the Coral Gables Canal. The increase in salinity interpreted for both Biscayne and Florida Bays in the early 1900s through the 1970s is likely related to the increased development of the canal system and modifications in surface-water drainage. This is consistent with the progressive inland saltwater intrusion. Post-1940 water-management practices to control water discharge greatly affected the Biscayne Bay ecosystem by increasing the frequency, and particularly the magnitude, of salinity fluctuations. By altering the natural variability in freshwater discharge to Biscayne Bay, the natural cycles of the nearshore marine organisms were disrupted, resulting in biotic fluctuations similar to the frequency and magnitude of the salinity changes. 


\section{Selected References}

Anderson, J.R., Hardy, E.E., Roach, J.T., and Witmer, R.E., 1976, A land use and land cover classification system for use with remotely sensed data: U.S. Geological Survey Professional Paper 964, 28 p.

Blaney, H.F., Rich, L.R., Criddle, W.D., and others, 1952, Consumptive use of water: Transactions of the American Society of Civil Engineers, no. 117, p. 948-967.

Blaney, H.F., and Criddle, W.D., 1950, Determining water requirements in irrigated areas from climatological and irrigation data: U.S. Soil Conservation Service Technical Paper 96, 48 p.

Blaney, H.F., and Criddle, W.D., 1962, Determining consumptive use and irrigation water requirements: U.S. Department of Agriculture Technical Bulletin 1275, $64 \mathrm{p}$.

Calver, J.L., 1957, Mining and mineral resources: Florida Geological Survey Bulletin $39,125 \mathrm{p}$

Cantillo, A.Y., Hale, K., Collins, E., Pikula, L., and Caballero, R., 2000, Biscayne Bay: Environmental history and annotated bibliography: National Oceanic and Atmospheric Administration Technical Memorandum NOS NCCOS CCMA 145, $116 \mathrm{p}$.

Carson, J.M., 1916, Back to Broward: Pamphlet for "Back to Broward League," 28 p.

Cohen, A.D., and Spackman, Jr., William, 1984, The petrology of peats from the Everglades and coastal swamps of southern Florida; in P.J. Gleason, ed., Environments of South Florida, Present and Past II: Miami Geological Society, p. 352374.

Cooper, H.H., Jr., 1959, A hypothesis concerning the dynamic balance of fresh water and salt water in a coastal aquifer: Journal of Geophysical Research, v. 64, no. 4, p. 461-467.

Cooper, H.H., Jr., 1964, A hypothesis concerning the dynamic balance of fresh wate and salt water in a coastal aquifer; in H.H. Cooper, Jr., F.A. Kohout, H.R. Henry, and R.E. Glover, Sea Water in Coastal Aquifers: U.S. Geological Survey WaterSupply Paper 1613-C, p. C1-C12.
Costanza, Robert, 1975, The spatial distribution of land use subsystems, incoming energy and energy use in south Florida from 1900 to 1973: University of Florida, M.A. Thesis, 204 p.

Cressler, Alan, 1993, The Caves of Dade County, Florida, in Georgia Underground: Dogwood City Grotto, Inc. of the National Speleological Society, Inc., v. 30, no. 3, p. 9-16.

Cunningham, K.J., 2004, Application of ground-penetrating radar, digital optical borehole images, and cores for characterization of porosity, hydraulic conductivity, and paleokarst in the Biscayne aquifer, southeastern Florida, USA: Journal of Applied Geophysics, v. 55, p. 66-76.

Cunningham, K.J., Carlson, J.L., Wingard, G.L., Robinson, Edward, and Wacker, M.A., 2004, Characterization of aquifer heterogeneity using cyclo-stratigraphy and geophysical methods in the upper part of the Biscayne aquifer, southeastern Florida: U.S. Geological Survey Water Resources Investigations Report 03-4208, 66 p., 5 pls.

Cunningham, K.J., Renken, R.A., Wacker, M.A., and Zygnerski, Michael, 2003, Application of carbonate cyclostratigraphy to delineate porosity and preferential flow and to assess advective transport in karst limestone of the Biscayne aquifer, SE Florida, USA: Abstract, Geological Society of America Annual Meeting, Abstracts with Programs, Seattle, Washington.

Dade County Lake Belt Plan Implementation Committee, 1997, Progress Report, December 1997: http://www.sfwmd.gov/org/pld/proj/lakebelt/documents/lakebelt97.pdf (accessed August 5, 2003).

Davis, J.H., Jr., 1943, The natural features of southern Florida, especially the vegetation, and the Everglades: Florida Geological Survey Bulletin 25, 311 p.

Davis, S.M., Gunderson, L.H., Park, W.A., Richardson, J.R., and Mattson, J.E., 1994, Landscape dimension, composition, and function in a changing Everglades Ecosystem; in S.M. Davis and J.C. Ogden, Everglades: The Ecosystem and Its Restoration: Delray Beach, Florida, St. Lucie Press, p. 419-444.

Duever, M.J., Meeder, J.F., Meeder, L.C., and McCollom, J.M., 1994, The climate of south Florida and its role in shaping the Everglades ecosystem; in Everglades The ecosystem and its restoration: Delray Beach, Florida, St. Lucie Press, p. 225-289.

Earth Satellite Corporation, 2004, Satellite image of southeastern Florida, April 1999: EarthSat, Baltimore, Maryland. 
Edgerton, C.D., 1974, Effects of urbanization upon the availability of construction minerals in southeastern Florida: Bureau of Mines Information Circular 8664, U.S. Department of the Interior.

Fennema, R.L., Neidrauer, C.J., Johnson, R.A., MacVicar, T.K., and Perkins, W.A., 1994, A computer model to simulate natural Everglades hydrology, in Everglades - The ecosystem and its restoration: Delray Beach, Florida, St. Lucie Press, p. 249-289.

Fies, M.A., Renken, R.A., and Komlos, S.B., 2002, Considerations for regional ASR in restoring the Florida Everglades, USA; in P.J Dillion, Management of Aquifer Recharge for Sustainability - Proceedings of the 4th International Symposium on Artificial Recharge, Adelaide, Australia, September 22-26, 2002: The Netherlands, A.A. Balkema Publishers, p. 341-346.

Fischer, J.N., 1980, Evaluation of a cavity-riddled zone of the shallow aquifer near Riviera Beach, Palm Beach County, Florida: U.S. Geological Survey WaterResources Investigations Report 80-60, 39 p.

Fish, J.E., 1988, Hydrogeology, aquifer characteristics, and ground-water flow of the surficial aquifer system, Broward County, Florida: U.S. Geological Survey WaterResources Investigations Report 87-4034, 92 p, 10 pls.

Fish, J.E., and Stewart, Mark, 1991, Hydrogeology of the surficial aquifer system, Dade County, Florida: U.S. Geological Survey Water-Resources Investigations Report 90-4108, 50 p, 11 pls.

Fitterman, D.V., and Deszcz-Pan, M., 1999, Geophysical mapping of saltwater intrusion in Everglades National Park: 3rd International Symposium on Ecohydraulics, Salt Lake City, Utah, July 12-16, 1999, p. 18.

Florida Department of Transportation, 1985, Land use, land cover and forms classification system manual, procedure number 550-010-001-A.

Frederick, Rod, Goo, Robert, Corrigan, Mary Beth, Bartow, Susan, and Billingsley, Michelle, 1997, Economic benefits of urban runoff controls: Plenary Proceedings of Watershed ' 96 - Moving Ahead Together, Baltimore, Maryland, June 8-12, 1997, p. 279-285.

Garcia-Benochea, J.I., Sproul, C.R., Vernon, R.O., and Woodward, H.J., 1973, Artificial recharge of treated waste waters and rainfall runoff into deep saline aquifers of peninsula Florida; in Jules Braunstein, ed., Second International Symposium on Underground Waste Management and Artificial Recharge, p. $505-525$.
George, P.S., 1996, Miami, the first hundred years, South Florida History Magazine, v. 24, no. 2: http://www.historical-museum.org/history/sfhm242.htm (accessed August 5, 2003).

Gleason, P.J., Cohen, A.D., Brooks, H.K, Stone, P.A., Goodrick, R.L., and Spackman, William, 1984, The environmental significance of Holocene sediments from the Everglades and saline tidal plain; in P.J. Gleason, ed., Environments of South Florida, Present and Past II: Miami Geological Society, p. 297-351.

Gunter, Herman, 1927, Statistics of mineral production in Florida during 1925: Eighteenth Annual Report, Florida Geological Survey.

Halley, R.B., 2002, Florida's murky past, Florida Bay watch header: Florida Bay Watch Report, available at http://sofia.usgs.gov/publications/reports/flbay_murky/ (updated October 11, 2002).

Halley, R.B., Cronin, T.M., Wingard, G.L., and Ishman, S.E., 1998, Increased salinity of Florida Bay and saltwater intrusion of the Biscayne aquifer during the early $20^{\text {th }}$ century - Simultaneous consequences of falling water tables along the margins of the Everglades: 1998 Florida Bay Science Conference Abstracts, available at http://www.aoml.noaa.gov/flbay/halleyetal.html

Halley, R.B., and Roulier, L.M., 1999, Reconstructing the history of eastern and central Florida Bay using mollusk-shell isotope records: Estuaries, v. 22, p 358-368.

Hantush, M.S., and Jacob, C.E., 1955, Nonsteady radial flow in an infinite leaky aquifer: American Geophysical Union Transactions, v. 36, no. 1, p. 95-100.

Hebert, P. J., Jarrell, J.D., and Mayfield, M., 1992, The deadliest, costliest, and most intense hurricane of this century (and other frequently requested facts): National Oceanic and Atmospheric Administration Technical Memorandum NWS NHC-31, $40 \mathrm{p}$.

Hebert, P. J., Jarrell, J.D., and Mayfield, M., 1993, The deadliest, costliest, and most intense United States hurricanes of this century: National Oceanic Atmospheric Administration Technical Memorandum NWS-NHC-31, 41 p.

Hickey, J.J., and Vecchioli, John, 1986, Subsurface injection of liquid waste with emphasis on injection practices in Florida: U.S. Geological Survey Water-Supply Paper 2281, 24 p. 
Hittle, C.D., 1999, Delineation of saltwater intrusion in the surficial aquifer system in eastern Palm Beach, Martin, and St. Lucie Counties, Florida, 1997-98: U.S. Geological Survey Water-Resources Investigations Report 99-4214, 1 sheet.

Howie, B.B., 1987, Chemical characteristics of water in the surficial aquifer system, Broward County, Florida: U.S. Geological Survey Water-Resources Investigations Report, 86-4330, 2 sheets.

Hughes, J.L., 1979, Saltwater-barrier line in Florida: Concepts, considerations, and site examples: U.S. Geological Survey Water-Resources Investigations Report 79-75, 29 p.

Ingebritsen, S.E., McVoy, Christopher, Glaz, B., and Park, Winifred, 1999, Florida Everglades - Subsidence threatens agriculture and complicates ecosystem restoration; in D.L. Galloway, D.R. Jones, and S.E. Ingebritsen, eds., Land Subsidence in the United States: U.S. Geological Survey Circular 1182, p. 95-106.

Ishman, S.E., Cronin, T.M., Brewster-Wingard, G.L., Willard, D.A., and Verado, D.J., 1998, A record of ecosystem change, Manatee Bay, Barnes Sound, Florida: Journal of Coastal Research no. 26., p. 125-138.

Jacobs, Jennifer, and Satti, S.R., 2001, Evaluation of reference evapotranspiration methodologies and AFSIR crop water use simulation model: St. Johns Water Management District, SJRWMD Contract No. SD325AA, 114 p.

Jensen, M.E., Burman, R.D., and Allen, R.G., 1990, Evapotranspiration and irrigation water requirements: American Society of Civil Engineers Manual No. 70, $332 \mathrm{p}$.

Jones, L.A., 1948, Soils, geology, and water control in the Everglades region: University of Florida Agricultural Experiment Station Bulletin 442, 168 p.

Klein, Howard, 1957, Salt-water encroachment in Dade County, Florida: Florida Geological Survey Information Circular 9, 17 p.

Klein, Howard, Armbruster, J.T., McPherson, B.F., and Freiberger, H.J., 1975, Water and the south Florida environment: U.S. Geological Survey Water-Resources Investigations Report 24-75, 165 p.

Klein, Howard, and Hull, J.E., Biscayne aquifer, southeast Florida: U.S. Geological Survey Water-Resources Investigations Report 78-107, 52 p.
Klein, Howard, and Ratzlaff, K.W., 1989, Changes in saltwater intrusion in the Biscayne aquifer, Hialeah-Miami Springs area, Dade County, Florida: U.S. Geological Survey Water-Resources Investigations Report 87-4249, 1 sheet.

Klein, Howard, and Waller, B.G., 1985, Synopsis of saltwater intrusion in Dade County, Florida, through 1984: U.S. Geological Survey Water-Resources Investigations Report 85-4101, 1 sheet.

Knetsch, Joe, and Ethridge, Laura, 1992, A historical overview of Broward County agriculture, 1915-1940: Broward Legacy, v. 15, no. 1-2, p. 21-27.

Kohout, F.A., 1960, Cyclic flow of salt water in the Biscayne aquifer of southeastern Florida: Journal of Geophysical Research, v. 65, no. 7, p. 2133-2141.

Kohout, F.A., 1964, The flow of fresh water and salt water in the Biscayne aquifer of the Miami area; in Sea Water in Coastal Aquifers: U.S. Geological Survey WaterSupply Paper 1613-C, p. C12-32.

Kohout, F.A., and Kolipinski, M.C., 1967, Biological zonation related to groundwater discharge along the shore of Biscayne Bay, Miami, Florida; in G.H. Lauff (ed.), Estuaries: American Association for the Advancement of Science, Publication No. 83, p. 488-499.

Koszalka, E.J., 1995, Delineation of saltwater intrusion in the Biscayne aquifer, eastern Broward County, Florida, 1990: U.S. Geological Survey Water-Resources Investigations Report 93-4164, 1 sheet.

Land, L.F., Rodis, H.G., and Schneider, J.J., 1973, Appraisal of the water resources of eastern Palm Beach County, Florida: Florida Geological Survey Report of Investigations 67, $64 \mathrm{p}$.

Langevin, C.D., 2001, Simulation of ground-water discharge to Biscayne Bay, southeastern Florida: U.S. Geological Survey Water-Resources Investigations Report 00-4251, $127 \mathrm{p}$.

Leach, S.D., and Grantham, R.G., 1966, Salt-water study of the Miami River and its tributaries, Dade County Florida: Florida Geological Survey Report of Investigation 45.

Leach, S.D., Klein, Howard, and Hampton, E.R., 1972, Hydrologic effects of water control and management of southeastern Florida: Florida Geological Survey Report of Investigations 60, 115 p. 
Leighton, M.O., 1912, National Aspect of Swamp Drainage: Reclamation of Wet Lands in the United States, Resolutions of the National Drainage Congress, 62D Congress, 2nd Session, Senate Document No. 877, p 5-13.

Light, S.S., and Dineen, J.W., 1994, Water control in the Everglades: A historical perspective; in S.M. Davis and J.C. Ogden, ed., Everglades - The Ecosystem and Its Restoration: Delray Beach, Florida, St. Lucie Press, p. 47-84.

MacVicar, T.K., Van Lent, T., and Castro, A., 1984, South Florida Water Management Model documentation report: West Palm Beach, South Florida Water Management District Technical Publication 84-3.

Marella, R.L., 1988, Water withdrawals, use, and trends in Florida, 1985, U.S. Geological Survey Water-Resources Investigations Report 88-4103, 43 p.

Marella, R.L., 1992, Factors that affect public-supply water use in Florida, with a section on projected water use to the year 2020: U.S. Geological Survey WaterResources Investigations Report 91-4123, 35 p.

Marella, R.L., 1999, Water withdrawals, use, discharge, and trends in Florida, 1995 U.S. Geological Survey Water-Resources Investigations Report 99-4002, 88 p.

Marella, R.L., and Singleton, V.D., 1988, Metering methods and equipment used for monitoring irrigation in the St. Johns River Water Management District Report.

McIvor, C.C., Ley, J.A., and Bjork, R.D., 1994, Changes in freshwater inflow from the Everglades to Florida Bay including effects on biota and biotic processes: A review; in S.M. Davis, and J.C.Ogden, eds., Everglades - The Ecosystem and its Restoration: Delray Beach, Florida, St. Lucie Press, p. 117-146.

McKenzie, D.J., 1995, Water quality of the Boca Raton canal system and effects of the Hillsboro Canal inflow, southeastern Florida, 1990-91: U.S. Geological Survey Water-Resources Investigations Report 94-4128, 14 p.

McNally, David, 1999, The Everglades - An environmental history: Gainesville, University Press of Florida, 215 p.

McPherson, B.F., Hendrix, G.Y., Klein, Howard, and Tyus, H.M., 1976, The environment of south Florida, a summary report: U.S. Geological Survey Professional Paper 1011, $81 \mathrm{p}$.

Mead, D.W., Hazen, Allen, and Metcalf, Leonard, 1912, Report on the drainage of the Everglades of Florida, with special reference to the lands of the Everglades Land Sales Company, Everglades Sugar and Land Company in the vicinity of Miami, Florida: New York, N.Y., 39 p.
Merritt, M.L., 1989, A review of factors affecting recovery of freshwater stored in saline aquifers: Artificial Recharge of Ground Water Symposium, Irrigation Division, American Society of Civil Engineers, p. 367-375.

Merritt, M.L., 1996a, Simulation of the water-table altitude in the Biscayne aquifer, southern Dade County, Florida, water years 1945-1989: U.S. Geological Survey Water-Supply Paper 2458, 148 p.

Merritt, M.L., 1996b, Assessment of saltwater intrusion in southern coastal Broward County, Florida: U.S. Geological Survey Water-Resources Investigations Report 96-4221, $131 \mathrm{p}$.

Meyer, W.B., 1994, When dismal swamps became priceless wetlands: American Heritage, p. 109-116.

Miller, J.A., 1997, Hydrogeology in Florida; in A.F. Randazzo and D.S. Jones, eds., The Geology of Florida: Gainesville, University Press of Florida, p. 69-88.

Miller, W.L., 1988, Description and evaluation of urban and agricultural development on the surficial aquifer system, Palm Beach County, Florida: U.S. Geological Survey Water-Resources Investigations Report 88-4056, 58 p.

National Research Council, 2001, Aquifer storage and recovery in the Comprehensive Everglades Restoration Plan: Washington, D.C., National Academy Press, $58 \mathrm{p}$.

National Research Council, 2002, Regional Issues in aquifer storage and recovery for Everglades restoration - A review of the ASR Regional Study Project Management Plan of the Comprehensive Everglades Restoration Plan: Washington, D.C., National Academy Press, 75 p.

Northwest Dade County Freshwater Lake Plan Implementation Committee (Lake Belt Committee), 1997, Northwest Dade County Freshwater Lake Belt Plan "Making a Whole, Not Just Holes": West Palm Beach, South Florida Water Management District, February 1997, 29 p.

Parker, G.G., 1945, Saltwater encroachment in southern Florida: American Water Works Association Journal, v. 37, no. 6, p. 526-542.

Parker, G.G., Ferguson, G.E., Love, S.K., and others, 1955, Water resources of southeastern Florida, with special reference to the geology and ground water of the Miami area: U.S. Geological Survey Water-Supply Paper 1255, 965 p. 
Reese, R.S., 2002, Inventory and review of aquifer storage and recovery in southern Florida: U.S. Geological Survey Water Resources Investigations Report 02-4036, $56 \mathrm{p}$.

Reese, R.S., and Cunningham, K.J., 2000, Hydrogeology of the gray limestone aquifer in southern Florida: U.S. Geological Survey Water-Resources Investigations Report 99-4213, 224 p.

Rodis, H.G., 1973, Encroaching salt water in northeast Palm Beach County, Florida: Florida Bureau of Geology Map Series 59.

Rodis, H.G., and Land, L.F., 1976, The shallow aquifer - A prime freshwater resource in eastern Palm Beach County, Florida: U.S. Geological Survey WaterResources Investigations Report 76-21, 12 p.

Schroeder, M.C., Klein, Howard, and Hoy, N.D., 1958, Biscayne aquifer of Dade and Broward Counties, Florida: Florida Geological Survey Report of Investigations 17, $56 \mathrm{p}$.

Schroeder, M.C., Milliken, D.L., and Love, S.K., 1954, Water resources of Palm Beach County: Florida Geological Survey Report of Investigations 13, 63 p.

Scott, W.B., 1977, Hydraulic conductivity and water quality of the shallow aquifer, Palm Beach County, Florida: U.S. Geological Survey Water-Resources Investigations Report 76-119, 22 p.

Scott, W.B., Land, L.F., and Rodis, H.G., 1977, Saltwater intrusion in the shallow aquifer in Palm Beach and Martin Counties, Florida: U.S. Geological Survey Water-Resources Investigations Report 76-135, 1 sheet.

Shaler, N.S., 1890, General account of the fresh-water morasses of the United States: U.S. Geological Survey Annual Report 10, p. 255-339.

Sherwood, C.B., and Klein, Howard, 1963, Surface- and ground-water relation in a highly permeable environment: International Association of Scientific Hydrology, v. 63 , p. $454-468$.

Sherwood, C.B., McCoy, H.J., and Galliher, C.F., 1973, Water resources of Broward County, Florida: Florida Geological Survey Report of Investigation 65, 141 p.

Shine, M.J., Padget, D.G.J., and Barfknecht, W.M., 1989, Ground water resource assessment of Palm Beach County, Florida: South Florida Water Management District Technical Publication 89-4, pt. I, 372 p.
Sonenshein, R.S., 1997, Delineation and extent of saltwater intrusion in the Biscayne aquifer, eastern Dade County, Florida, 1995: U.S. Geological Survey WaterResources Investigations Report 96-4285, 1 sheet.

Sonenshein, R.S., and Koszalka, E.J., 1996, Trends in water-table altitude (1984-93) and saltwater intrusion (1974-93) in the Biscayne aquifer, Dade County, Florida: U.S. Geological Survey Open-File Report 95-705, 2 sheets.

Sonntag, W.H., 1987, Chemical characteristics of water in the surficial aquifer system, Dade County, Florida: U.S. Geological Survey Water-Resources Investigations Report 87-4080, 42 p, 2 pls.

South Florida Water Management District, 2000, Lower East Coast Regional Water Supply Plan Planning Document, 358 p.

South Florida Water Management District, 2003, Natural System Model Online Documentation, NSM v. 4.6, Topographic map: http://www.sfwmd.gov/org/pld/ hsm/models/nsm/nsm46_topo.pdf

Stephens, J.C., and Johnson, L., 1951, Subsidence of organic soils in the upper Everglades region of Florida, Soil Science Society of Florida Proceedings, v. XI, p. 191-237.

Stephens, J.C., 1984, Subsidence of organic soils in the Florida Everglades - A review and update; in P.J. Gleason, ed., Environments of South Florida, Present and Past II: Miami Geological Society, p. 375-384

Swayze, L.J., and Miller, W.L., 1984, Hydrogeology of a zone of secondary permeability in the surficial aquifer of eastern Palm Beach County, Florida: U.S. Geological Survey Water-Resources Investigations Report 83-4249, 38 p.

Turner II, B.L., and Meyer, W.B., 1994, Global land-use and land-cover perspective-An overview; in W.B. Meyer and B.L., Turner II, eds., Changes in Land Use and Land Cover - A Global Perspective: New York, N.Y., Cambridge University Press, p. 3-10.

U.S. Army Corps of Engineers and South Florida Water Management District, 1999, Central and Southern Florida Flood Control Project Comprehensive Review Study: Final Integrated Feasibility Report and Programmatic Environmental Impact Statement, U.S. Army Corps of Engineers, Jacksonville District, Jacksonville, Florida, and South Florida Water Management District, West Palm Beach, Florida. 
U.S. Army Corps of Engineers and South Florida Water Management District, 2002, Central and Southern Florida Flood Control Project Management Plan, Regional Aquifer Storage and Recovery Study: Draft PMP, v. 4, 104 p.

U.S. Bureau of the Census, 2004, State of Florida, Decennial Report of the Census: Compiled from various files, 1900 to 2000 .

U.S. Congress, 1911, Everglades of Florida Acts, Reports, and other Papers, State and National, Relating to the Everglades of the State of Florida and their Reclamation: Senate Document 89, 62nd Congress, 1st session. 193 p.

U.S. Congress, 1913, Florida Everglades, Report of the Florida Everglades Engineering Commission: Senate Document No. 379, 63rd Congress, 2nd Session, $148 \mathrm{p}$.

U.S. Department of the Interior, 1969, Environmental impact of the Big Cypress Jetport, $155 \mathrm{p}$.

U.S. Environmental Protection Agency, 1979, Federal Register Notice, October 11, 1979 , v. 44 , no. 198

U.S. Environmental Protection Agency, 1999, Water-quality standards and criteria website: http://www.epa.gov/seahome/wqs.html (accessed March 28, 2002).
U.S. Geological Survey, 2004, Historical water use in Florida: http://fl.water.usgs. gov/WaterUse/Water_Use_web/hwu_fl.htm

Vorhis, R.C., 1948, Geology and ground water of the Fort Lauderdale area, Florida: Florida Geological Survey Report of Investigations 6, 43 p.

Wanless, H.R., Cotrell, D., Parkinson, R., and Burton, E., 1984, Sources and circulation of turbidity, Biscayne Bay, Florida: Report submitted to Dade County and Florida Sea Grant, 499 p.

Ward, W.C., Cunningham, K.J., Renken, R.A., Wacker, M.A., and Carlson, J.L., 2003, Sequence-stratigraphic analysis of the Regional Observation Monitoring Program (ROMP) 29A test corehole and its relation to carbonate porosity and regional transmissivity in the Floridan aquifer system, Highlands County Florida, U.S. Geological Survey Open-File Report 03-201, 34 p.

Williams, A.P., 1883, North to south through the Everglades in 1883: The account of the second expedition into the Everglades by the New Orleans Times-Democrate; in M.K. Wintringham, Tequesta, v. 23, p. 59-93. 